\title{
42. CATALOGUE OF CALCAREOUS NANNOPLANKTON FROM SEDIMENTS OF NEOGENE AGE IN THE EASTERN NORTH ATLANTIC AND MEDITERRANEAN SEA
}

\author{
Herbert Stradner, Geological Survey of Austria, Austria, Vienna
}

\section{INTRODUCTION}

The pictorial documentation (Plates 1 through 50) of the nannoplankton recovered during Leg 13 offers to the reader a mere glimpse of the wealth of shapes in these minute calcite forms found at the sea bottom of the eastern North Atlantic and Mediterranean (Sites 120 through 134E). Taking into account the vast diversity of the nannoplankton and the great variability of individual species, the small selection of pictures presented here gives no more than a few examples. Out of a total of 872 microscope slides and several dozen carbon replicas, only a few were photographed. Only a limited number of the microscope slides and several dozen replicas were used to produce several hundred micrographs; only part of these are shown here.

Some remarks on the composition of the Neogene nannofossil assemblages in the Mediterranean, and some of the problems of biostratigraphy and chronostratigraphy are outlined here. One new species, Discoaster icarus n. sp., is described.

More detailed discussion of the nannoplankton biostratigraphy, along with floral lists, can be found in the site reports. The zonation proposed by Martini and Worsley (1970) was mostly used.

\section{REMARKS ON NANNOPLANKTON BIOSTRATIGRAPHY}

\section{Miocene}

The coccoliths and discoasters recovered from the Miocene during Leg 13 in the Mediterranean are in a comparatively good state of preservation, but are not so abundant as in the Pliocene. Ceratoliths were not encountered in Miocene sediments.

Plates $39-42$ show that variation within the discoaster species, expecially $D$. variabilis, $D$. bollii and $D$. kugleri, is rather wide. In the Miocene, the assignment of an assemblage to a certain zone is complicated by reworking and by the lack of some of the key species of the Standard Nannoplankton Zonation, as listed by Martini (1971). Lopadoliths of the genus Scyphosphaera are either rare or entirely absent in the Miocene cores of the Mediterranean.

Miocene nannoplankton were found in the following cores: 13-121 (16-24), 13-124 (7), 13-126 (5-6), 13-126A (1), 13-129 (3), 13-129A (3), 13-129B (2), 13-132 (21-27), 13-134 (7).

Lower Miocene assemblages with abundant discoasters of a heavy, robust type were found at Site 120 in the eastern Atlantic (Gorringe Bank) in the core catcher of Core 1. Overgrowths on asteroliths are observed (see Plates 43-47).
In the Middle Miocene of Site 126, the Catinaster coalitus group is not so characteristic, nor as well represented as in the Pacific Ocean. The discoasters are flatter and resemble those found in the middle Miocene of Rumania (Breschitza, Stradner and Papp, 1960), the so-called Discoaster musicus group.

In the Upper Miocene Core 134-7 an interesting discoaster development is represented by Discoaster icarus n. sp. The Discoaster variabilis evolution has been continued there via $D$. variabilis pansus into forms with their branched arms extended into flap-like wings. These extensions are not only present in large asteroliths but also in small specimens.

The transition from the Upper Miocene or Messinian to the Lower Pliocene nannoplankton seems to be marked in the Mediterranean by the replacement of large and heavy discoaster types of the $D$. variabilis group by assemblages with more delicate structure, accompanied by slender, three-horned ceratoliths (C. tricorniculatus). These latter nannoplankton assemblages of the $\mathrm{NN} 12$ (Ceratolithus tricorniculatus Zone) in the Mediterranean are considered here as post-Messinian or Lower Pliocene. According to Berggren, the N 18 Zone (foraminiferal), which embraces the NN 12 Zone (nannoplankton), straddles the Miocene/ Pliocene boundary, whereas in Martini and Worsley's nannoplankton zonation both the $\mathrm{N} 18$ and the NN 12 zones are listed as Upper Miocene. In the Mediterranean cores of Sites 132 and 134, a sharp boundary is marked by the change from Messinian nannoplankton without Ceratolithus tricorniculatus to the post-Messinian assemblages with this marker present.

Pliocene

Pliocene cores from the Mediterranean contain the most abundant and diverse assemblages. All the nannoplankton zones described by Hay \& Schmidt (1967), Gartner (1969) and Martini \& Worsely (1970) could be verified. Even the time-equivalent spacing was found to be identical to the one postulated for these biostratigraphic units in Atlantic and Pacific sediments, with the Discoaster pentaradiatus Zone being the shortest of all the Pliocene zones. In the Lower Pliocene of the Mediterranean the ceratoliths are not abundant; Ceratolithus rugosus is especially rare. Thus the NN $12 / \mathrm{NN} 13$ boundary is difficult to locate. The Scyphosphaera group (see Plates 22-25), and quantitative analyses of discoasters near the level of thier extinction, might furnish additional nannoplankton datum planes. As demonstrated by Takayama (1967, 1970, and 1972), the last evolutionary trend in discoasters before their extinction was the development of abundant three-rayed forms of the D. brouweri type assigned to Discoaster brouweri trithallus Takayama (=Discoaster triradiatus Tan Sin Hok). Assemblages typical of Takayama's D. brouweri trithallus Zone 


\begin{tabular}{lrcccc}
\hline Discoaster brouweri & 3-Rayed & 4-Rayed & 5-Rayed & 6-Rayed & 7-Rayed \\
\hline $13-125-4-1,150 \mathrm{~cm}$ & $31 \%$ & - & $2 \%$ & $67 \%$ & - \\
$13-125-4-2,60 \mathrm{~cm}$ & $30 \%$ & $1 \%$ & $1 \%$ & $68 \%$ & - \\
$13-125-4-2,30 \mathrm{~cm}$ & $23 \%$ & $1 \%$ & $1 \%$ & $73 \%$ & $2 \%$ \\
$13-125-4-2,60 \mathrm{~cm}$ & $34 \%$ & - & $3 \%$ & $63 \%$ & - \\
$13-125-4-2,90 \mathrm{~cm}$ & $26 \%$ & - & $2 \%$ & $72 \%$ & - \\
$13-125-4-3,60 \mathrm{~cm}$ & $31 \%$ & - & $1 \%$ & $68 \%$ & - \\
$13-125-4-4,120 \mathrm{~cm}$ & $25 \%$ & $1 \%$ & $1 \%$ & $73 \%$ & - \\
$13-125-4-6,75 \mathrm{~cm}$ & $5 \%$ & $1 \%$ & & $94 \%$ & - \\
\hline
\end{tabular}

are present in 13-125-4. The following percentages were observed from Section 6 to the top of Section 1, where the last bloom of Discoaster brouweri occurs.

These preliminary discoaster counts (a more detailed study is in progress) show that from an initial 5 percent tri-radiate forms and 94 percent six-rayed forms, the former increase to an average of about 29 percent, against about 69 percent six-rayed and 2 percent five-rayed forms from $13-125-4-4,120 \mathrm{~cm}$ up. This last evolutionary episode in the discoasters before their extinction is also evident in the descriptions of Lamont Core V 21-98, (western Pacific) between $270 \mathrm{~cm}$ and $210 \mathrm{~cm}$ (Takayama 1970). In the Chain 61 (171) core from the Mid-Atlantic Ridge, the discoaster extinction takes place between 420 and $400 \mathrm{~cm}$ (Berggren et al., 1967). In both these cores the change from a relatively rare to a dominant Globorotalia truncatulinoides takes place before the extinction of the Discoaster brouweri. In Lamont Core V 21-98 this event (extinction of discoasters) lies within the Olduvai, and in Chain 61 (171), above the Olduvai paleomagnetic event. Also in 13-125-4 there is an overlap of the last discoaster populations with truncatulinoides in Section 5. If a sediment accumulation rate of $2.2 \mathrm{~cm} / 10^{3} \mathrm{y}$ is assumed, this interval corresponds to somewhat more than $0.2 \times 10^{6}$ years. This agrees with the observations in the Chain 61 (171) core of the Mid-Atlantic Ridge. If the Globorotalia truncatulinoides datum is taken at $1.85 \times 10^{6}$ years, the discoaster extinction, which followed more than 200,000 years later, took place between 1.65 and $1.60 \times 10^{6}$ years $\mathrm{BP}$, in post-Olduvai time (see Hays and Berggren, 1971, p. 676). Thus, even without paleomagnetic data, the upper limit of the Olduvai event can be placed between Section 5 and the top of Section 2 in Core 4 at Site 125 in the Ionian Basin.

Pliocene nannoplankton were found in the following cores: $13-121$ (7-15), 13-122 (1-4), 12-123 (3-6), 13-124 (2-5), 13-125 (4-8), 13-125A (1-6), 13-127 (1B and 19), 13-129 (CB 2), 13-129B (CB 1), 13-132 (8-21), 13-134 (3, 5-7), 134E (2, CC).

\section{Quaternary}

The Quaternary nannoplankton assemblages of the Mediterranean contain abundant coccoliths. There are occasional discoasters which are obviously reworked (Paleocene to Pliocene species), except Discoaster perplexus, which does not fit into this genus, and should be assigned either to the genus Cyclococcolithus or Oolithothus. At Sites 127 and 128, the relative abundance of Discoaster perplexus and Oolithothus antillarum (see Plate 12) was used to define the local sediment units in spite of the fact, that both these species are known from older sediments. The first occurrences listed there are not to be understood as worldwide first occurrences, but rather as first appearance in the Pleistocene column of these two sites.

The Pseudoemiliania lacunosa Zone (NN 19) and the overlying Gephyrocapsa oceanica Zone (NN 20) are not readily distinguished at Site 132, because $P$. lacunos $a$ has an extended range there up to the Emiliania huxleyi Zone (NN 21). Although Clocchiati (1971) claims that Gephyrocapsa oceanica and Emiliania huxleyi were found to occur on one and the same coccosphere, the terms Gephyrocapsa oceanica Zone (NN 20) and Emiliania huxleyi Zone (NN 21) ought to be retained.

At Sites 127, 128 and 132, Reticulofenestra pseudoumbilica was found in horizons in the lower and the middle Quaternary. These large coccoliths seem to be autochthonous and not reworked, at least in the Mediterranean they have a revival after their supposedly last occurrence at the end of the Reticulofenestra pseudoumbilica Zone (NN 15) in the lower Pliocene.

The occurrence of Braarudosphaera bigelowi in 132-8-4, $30 \mathrm{~cm}$ can be interpreted as sign of decreased salinity. Also. in 130-3, in the Levantine Basin, large specimens of Braarudosphaera bigelowi were found.

Quaternary nannoplankton were found in the following cores: 13-120 (1; Bits and Subs), 13-121 (1-6), 13-122 (1), $13-123$ (1-2), 13-124 (1), 13-125 (1-4), 13-126 (1-3), 13-127 (1-15), 13-127A (1-4), 13-128 (1-11), 13-130 (1-7), 13-130A (1), 13-131 (1-5), 13-131A (1), 13-132 (1-8), 13-133 (1), 13-134 (1-2), 13-134A (2), 13-134B (1), 13-134E (SWC 2).

\section{Description of the New Species \\ Family DISCOASTERIDAE Tan Sin Hok, 1927 Genus DISCOASTER Tan Sin Hok, 1927}

\section{Discoaster icarus n. $\mathrm{sp}$.}

Derivation of name: Ikaros, son of Daedalos, in Latin spelling "Icarus".

Diagnosis: A discoaster of the $D$. variabilis group with rays terminating in a wide-angle of bifurcation of branches with "flaps" between the branches. Larger asteroliths with diameter to about 30 microns, as well as small specimens, show these flap-like extensions. The center of the convex or distal side of Discoaster icarus n. sp. is decorated with a hexagonal prismatic knob and the rays are separated by straight suture lines. The concave or proximal side also shows straight suture lines but lacks a central knob. The membranes of the "flaps" are bent toward the concave side and are best seen in oblique side view. In some asteroliths they are bent so sharply that they can hardly be seen in plain view. 10).

Holotype: Prep. 13-134-7, CC, SD 1, (Plate 41, Figure

Paratypes: Prep. 13-134-7, CC, SD 1a, (Plate 41, Figure 11), Prep. 13-134-7, CC, SD 1b, specimen of Figure 1 (schematized).

Type locality: DSDP 13-134-7, CC, Balaeric Abyssal Plain/Sardinian Margin, lat. $30^{\circ} 11.70^{\prime} \mathrm{N}$, long. $7^{\circ} 18.25^{\prime} \mathrm{E}$.

Type level: Upper Miocene, Messinian.

\section{ACKNOWLEDGMENTS}

All transmission electron and light micrographs were taken by the author using the facilities of the ELMI-Lab of 


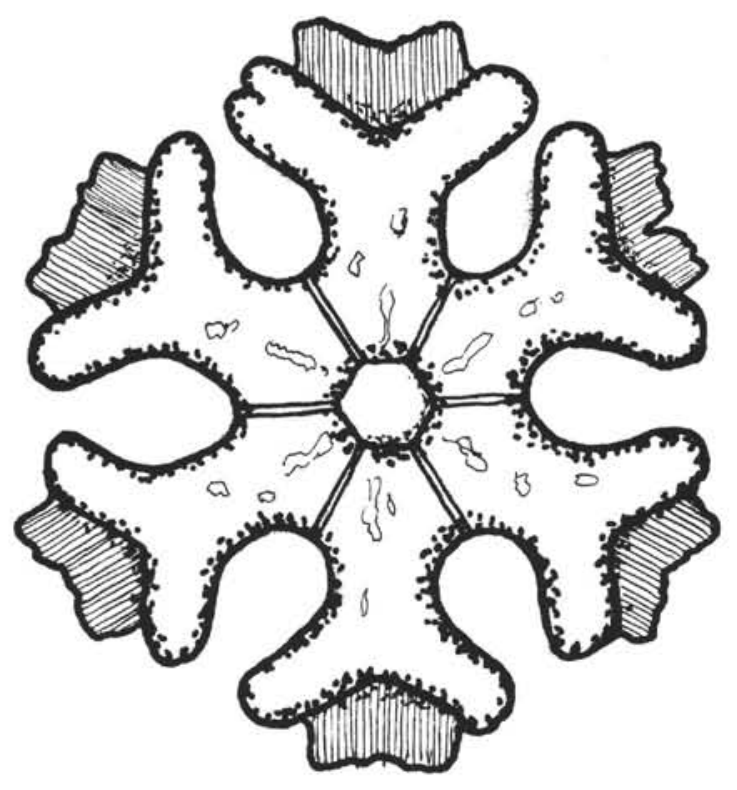

Figure 1. Sketch of Discoaster icarus n. sp. from Late Miocene (Messinian) sediments at Site 134 - Balearic Abyssal Plain. Sample Prep. 13-134-7 $C C, S D 1 b$.

the Geological Survey of Austria in Vienna with the kind permission of the Director, Dr. A. Ruttner. Helmut E. Franz, Labor. fur Elektronenmikroskopie, Zurich, took the scanning electron micrographs with the kind permission of Dr. H. M. Bolli. Plates were mounted on compiled by Mrs. Iris Zack of the Cartographic Section, Geological Survey of Austria. Mr. Otto Boehm prepared the carbon replicas for the transmission electron microscopy. My sincere thanks to all who contributed to this work. Since a future leg of the Deep Sea Drilling Project to the Mediterranean in 1974 is planned and additional time, personnel, and funds are available, work on Leg 13 nannoplankton is continued.

\section{REFERENCES}

Berggren, W. A., Phillips, J. D., Bertels, A. and Wall, D., 1967. Late Pliocene-Pleistocene stratigraphy in deep sea cores from the south-central North Atlantic. Nature. Lond. 216, 253.

Clocchiatti, M., 1971. Sur l'existence de coccospheres portant des coccoliths de Gephyrocapsa oceanica et de Emiliania huxleyi (Coccolithophorides). Comptes Rendues Acad. Sc. Paris. 273, 318.

Gartner, S., 1969. Correlation of Neogene planktonic foraminifera and calcareous nannofossil zones.

Hay, W. W. and Schmidt, R. R., 1967. Zonation of the Pliocene Interval: Hay, W. W., Mohler, Hans. P., Roth, P. H., Schmidt, R. R. and Boudreaux, J. E., In Calcareous Nannoplankton Zonation of the Cenozoic of the Gulf Coast and Caribbean-Antillean Area and Transoceanic Correlation Transactions of the Gulf Coast Association of Geological Societies, 17, 442 .

Hays, D. and Berggren, W. W., 1971. Quaternary Boundaries. The Micropaleontology of the Oceans. Riedel and Funnel (Ed.). Cambridge University Press, 1971.

Martini, E., 1971. Standard Tertiary and Quaternary calcareous nannoplankton zonation. In Farinacci, A. (Ed.). Proceedings of the II Planktonic Conference Roma 1970. Roma, Edizioni Technoscienza, 739, pl. $1-4$.

Martini, E. and Worsley, T., 1970. Standard Neogene Calcareous Nannoplankton Zonation. Nature. 225, 289.

Stradner, H. and Papp, A., 1961. Tertiare Discoasteriden aus Osterreich und deren stratigraphische Bedeutung mit Hinweisen auf Mexiko, Rumänien und Italien. Jahrb. Geol. Bundesanst. Wien, Sonderband 7, 159 pp. 42 pls.

Takayama, T., 1967. First report on nannoplankton of the upper Tertiary and Quaternary of the southern Kwanto Region, Japan. Jahrb. Geol. Bundesanst. Wien, 110, 169, pl. 1-10, 7 figs.

, 1970. The Pliocene-Pleistocene boundary in the Lamont Core V. 21-98 and at Le Castella, southern Italy. J. Mar. Geol. 6, 70, 5 figs. , 1972. Calcareous nannoplankton flora of the youngest Cenozoic of the Pacific Coastal Region of Japan. Science Reports of the Tohoku University, Japan. (In Press).

Tan Sin Hok, 1927. Discoasteridae incertae sedis. Akad Wet. Amsterdam. Proc. Sec. Sci. 30, 411, 14 figs. 


\begin{tabular}{|c|c|c|}
\hline & Plate(s) & Figure(s) \\
\hline $\begin{array}{l}\text { Braarudosphaera bigelowi (Gran and Braarud) } \\
\text { Deflandre }\end{array}$ & 36 & 10,11 \\
\hline Ceratolithus rugosus Bukry and Bramlette & 36 & 9 \\
\hline \multirow[t]{2}{*}{ Ceratolithus tricorniculatus Gartner } & 36 & $4-8$ \\
\hline & 37 & $1-6$ \\
\hline Coccolithus doronicoides Black and Barnes & 6 & 2,3 \\
\hline \multirow[t]{5}{*}{ Coccolithus pelagicus (Wallich) Schiller } & 1 & $1-6$ \\
\hline & 2 & $1-6$ \\
\hline & 38 & 4 \\
\hline & 46 & 6 \\
\hline & 47 & 4 \\
\hline Coccolithus sp. & 6 & 1 \\
\hline $\begin{array}{l}\text { Cyclicargolithus floridanus (Roth and Hay) } \\
\text { Bukry }\end{array}$ & 47 & $1-3,5,6$ \\
\hline \multirow[t]{2}{*}{ Cyclococcolithus aequiscutum Gartner } & 13 & 4 \\
\hline & 14 & 3 \\
\hline Cyclococcolithus cricotus Gartner & 13 & $1-3$ \\
\hline Cyclococcolithus leptoporus (Murray and & 7 & $1-5$ \\
\hline Blackman & 8 & $1,2,4,6$ \\
\hline \multirow[t]{4}{*}{ Cyclococcolithus macintyrei Bukry } & 8 & 3 \\
\hline & 9 & $1-6$ \\
\hline & 10 & $1-6$ \\
\hline & 31 & 11 \\
\hline Cyclococcolithus sp. & 12 & 10,11 \\
\hline Cyclolithella inflexa (Kamptner) & 14 & $4-6$ \\
\hline Cruciellipsis chiastia (Worsley) Thierstein & 49 & 4 \\
\hline \multirow{2}{*}{ Cruciellipsis cuvillieri (Manivit) Thierstein } & 49 & 3 \\
\hline & 50 & 4 \\
\hline Dinoflagellate fragments & 51 & $1-6$ \\
\hline \multirow[t]{2}{*}{ Discoaster asymmetricus Gartner } & 35 & $3-6$ \\
\hline & 36 & 2 \\
\hline Discoaster argutus Hay & 39 & 7 \\
\hline \multirow[t]{5}{*}{ Discoaster aulakos Gartner } & 40 & $3-8$ \\
\hline & 43 & $2,3,5,7,10$ \\
\hline & 44 & $2,3,6$ \\
\hline & 45 & $2-6$ \\
\hline & 46 & 2,4 \\
\hline \multirow{3}{*}{ Discoaster brouweri Tan Sin Hok } & 31 & $1,2,9,10$ \\
\hline & 34 & 4 \\
\hline & 36 & 3 \\
\hline Discoaster bollii Martini and Bramlette & 39 & $1,3,4$ \\
\hline Discoaster challengeri Bramlette and Riedel & 34 & 1,2 \\
\hline $\begin{array}{l}\text { Discoaster challengeri mediterraneus Cata and } \\
\text { Borsetti }\end{array}$ & 43 & 8,9 \\
\hline \multirow[t]{2}{*}{ Discoaster deflandrei Bramlette and Riedel } & 44 & $1,4,5$ \\
\hline & 46 & 3 \\
\hline \multirow[t]{2}{*}{ Discoaster dilatus } & 39 & 9 \\
\hline & 41 & 6 \\
\hline Discoaster divaricatus Hay & 39 & 8,11 \\
\hline \multirow[t]{2}{*}{ Discoaster icarus Stradner n. sp. } & 41 & $7,10,11$ \\
\hline & 42 & $1-6,9,10$ \\
\hline \multirow[t]{2}{*}{ Discoaster intercalaris Bukry } & 40 & 1,2 \\
\hline & 41 & 1 \\
\hline Discoaster kugleri Martini and Bramlette & 39 & 5 \\
\hline Discoaster loeblichï Bukry & 41 & 2,3 \\
\hline Discoaster musicus Stradner & 39 & 12 \\
\hline \multirow[t]{4}{*}{ Discoaster obtusus Gartner } & 32 & 5,6 \\
\hline & 43 & 4,6 \\
\hline & 45 & 1 \\
\hline & 46 & 1 \\
\hline \multirow[t]{2}{*}{ Discoaster pentaradiatus Tan Sin Hok } & 31 & 3-6 \\
\hline & 34 & 5,6 \\
\hline Discoaster preplexus Bramlette and Riedel & 8 & 5 \\
\hline & 12 & $7-9$ \\
\hline Discoaster saundersi Hay & 42 & 7,8 \\
\hline Discoaster stellulus Gartner & 39 & 2 \\
\hline Discoaster surculus Martini and Bramlette & 31 & 7,8 \\
\hline & 32 & $1-4$ \\
\hline & 33 & $1-6$ \\
\hline & 34 & 3 \\
\hline
\end{tabular}

Discoaster sp.

Discoaster tamalis Kamptner

Discoaster trinidadensis Hay

Discoaster variabilis Martini and Bramlette

Discoaster variabilis pansus Bukry and Percival

Discolithina macropora Deflandre

Gephyrocapsa aperta Kamptner

Gephyrocapsa oceanica Kamptner

Helicopontosphaera kamptneri Hay and Mohler

Lithostromation perdurum Deflandre

Micrantholithus obtusus Stradner

Nannoconus steinmanni Kamptner

Nannoconus bucheri Bronnimann

Oolithothus antillarum (Cohen)

Parhabdolithus embergeri Noel

Pontosphaera alboranensis Bartonlini

Pontosphaera japonica Takayama

Pontosphaera pauciforata (Kamptner)

Pontosphaera scutellum (Kamptner)

Pontosphaera sp.

Pseudoemiliania lacunosa Kamptner

Reticulofenestra pseudoumbilica (Gartner)

Rhabdosphaera clavigera Murray and

Blackman

Rhabdosphaera stylifera Lohmann

Rhabdothorax sp.

Scapholithus fossilis Deflandre

Scyphosphaera amphora Deflandre

Scyphosphaera apsteini Lohmann

Scyphosphaera halldali Deflandre

Scyphosphaera campanula Deflandre

Scyphosphaera expansa Bukry and Percival

Scyphosphaera globulata Bukry and Percival

Scyphosphaera intermedia Deflandre

Scyhosphaera sp.

347

$39 \quad 10$

$40 \quad 1,11$

$43 \quad 1,12$

$35 \quad 1-2$

$36 \quad 1$

12

$5,9,10$

4,5

8,9

12,13

5,6

1-6

1-4

$1-6$

10-12

10-12

$1,2,3$

4,5

6

1-6

1-6

$6,7,8$

5,6

5, 6

1,2

$3,4,5$

1,2

12

3-7

1-4

6

1-4

4-5

1-5

1-4

2

14

9

$1,2,5$

3-6

1-6

1-7

7

3

8,9

6

4

7

1, 2

3,5

8

Scyphosphaera porosa Kamptner

Scyphosphaera pulcherrima Deflandre

Scyphosphaera recurvata Deflandre

Scyphosphaera turris Kamptner

Sphenolithus abies Deflandre

Syracosphaera delmatica Kamptner

Syracosphaera molischi Schiller

Tessellatolithus dentatus $\mathrm{Haq}$

Thoracosphaera heimi (Lohmann) Kamptner

Thoracosphaera sp.

Umbilicosphaera mirabilis Lohmann

1,2

6

1,2

1,2

$3,4,5$

4

4

1,5

1

5,6

1,2

Watznaueria barnesae (Black) Perch-Nielsen 
PLATE 1
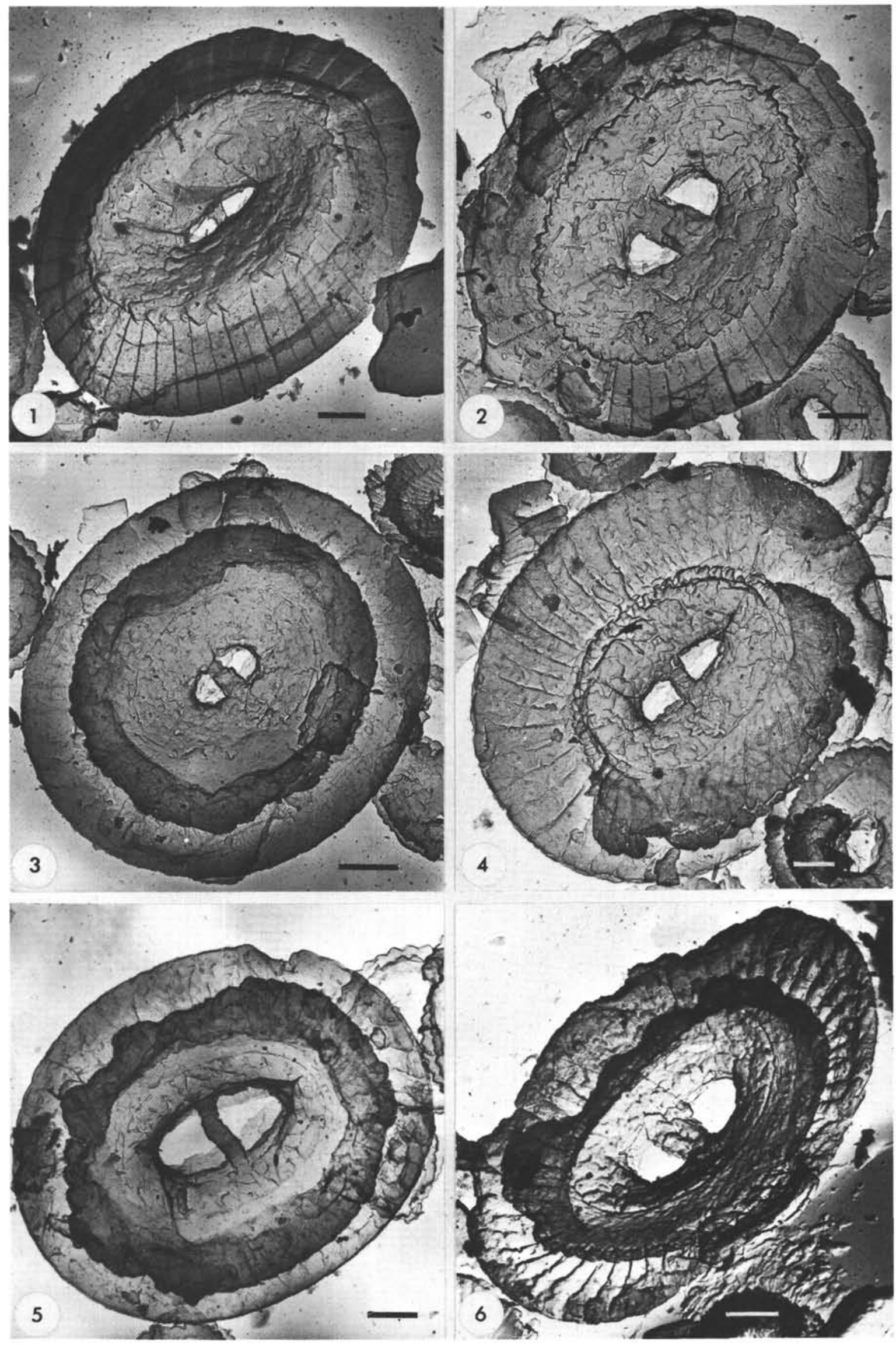
PLATE 2
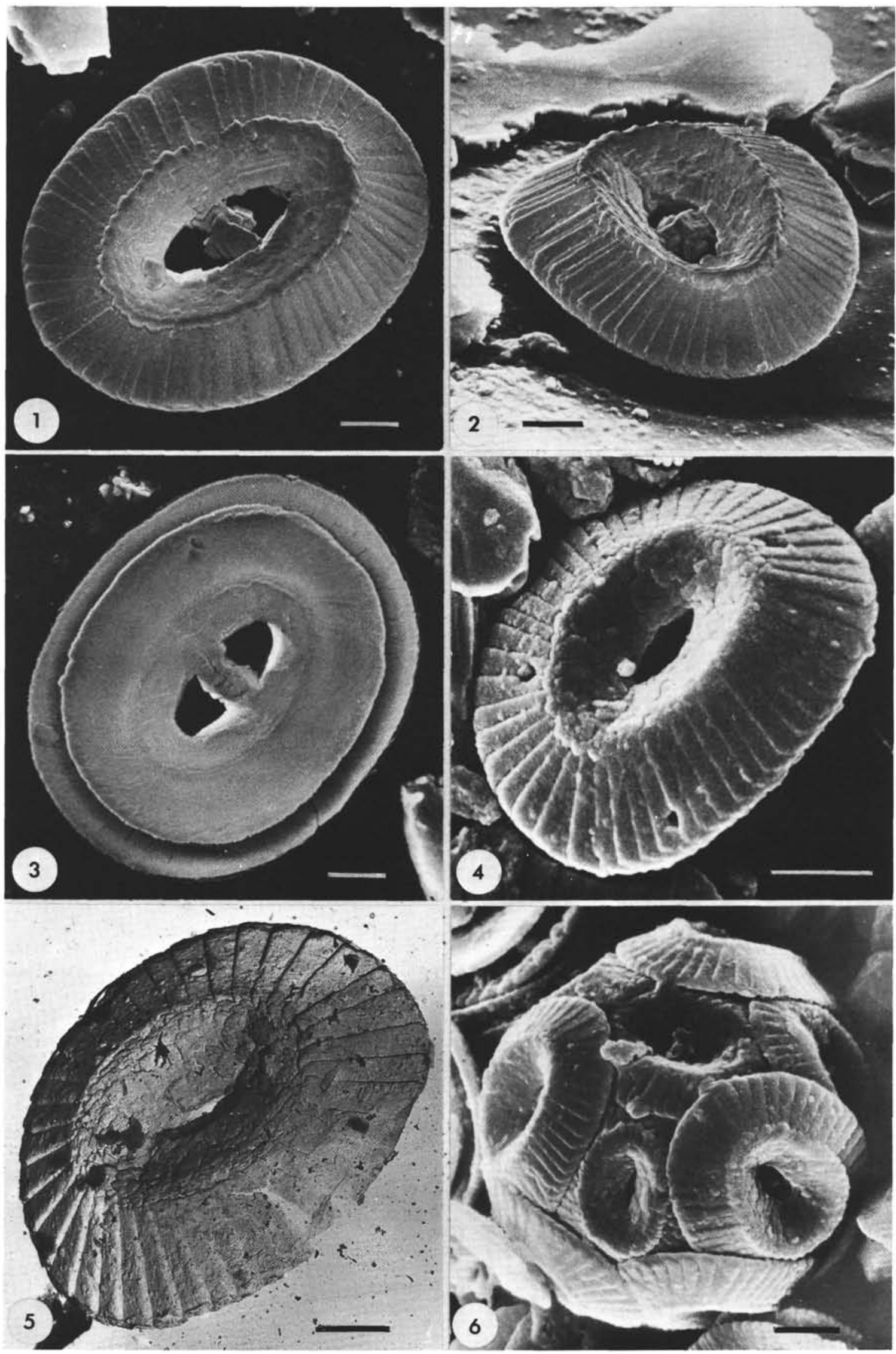
PLATE 3

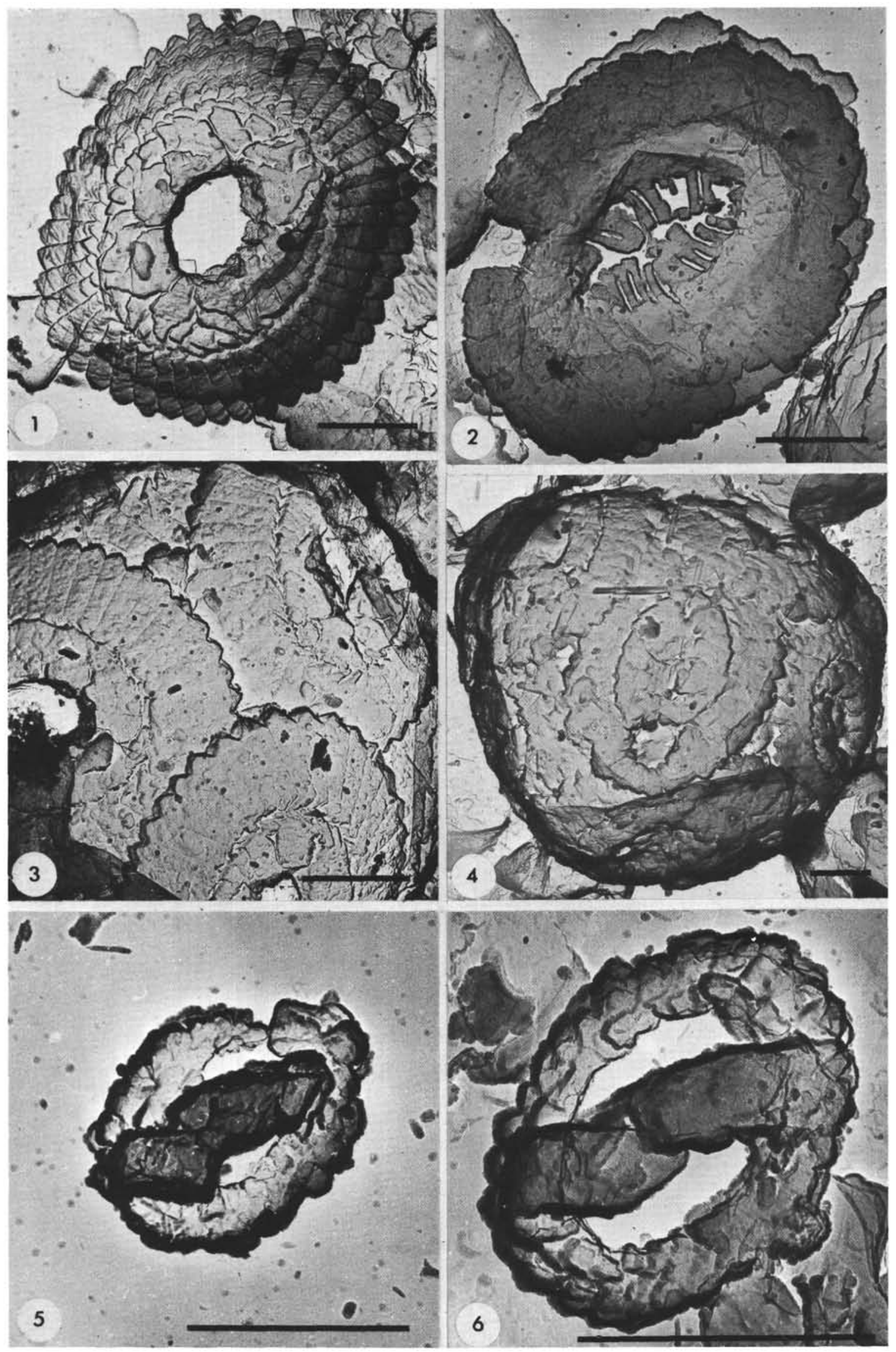


PLATE 4
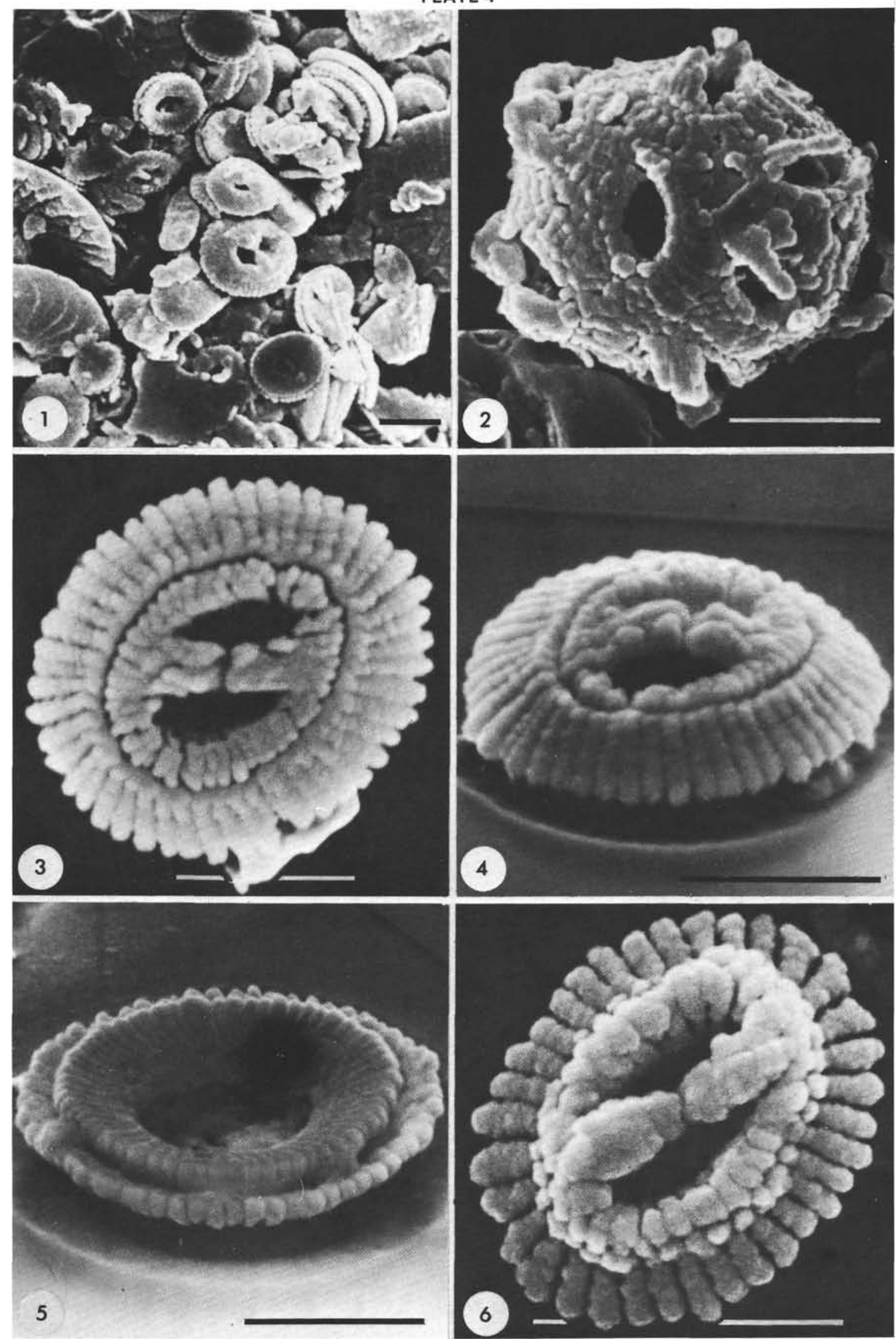
PLATE 5

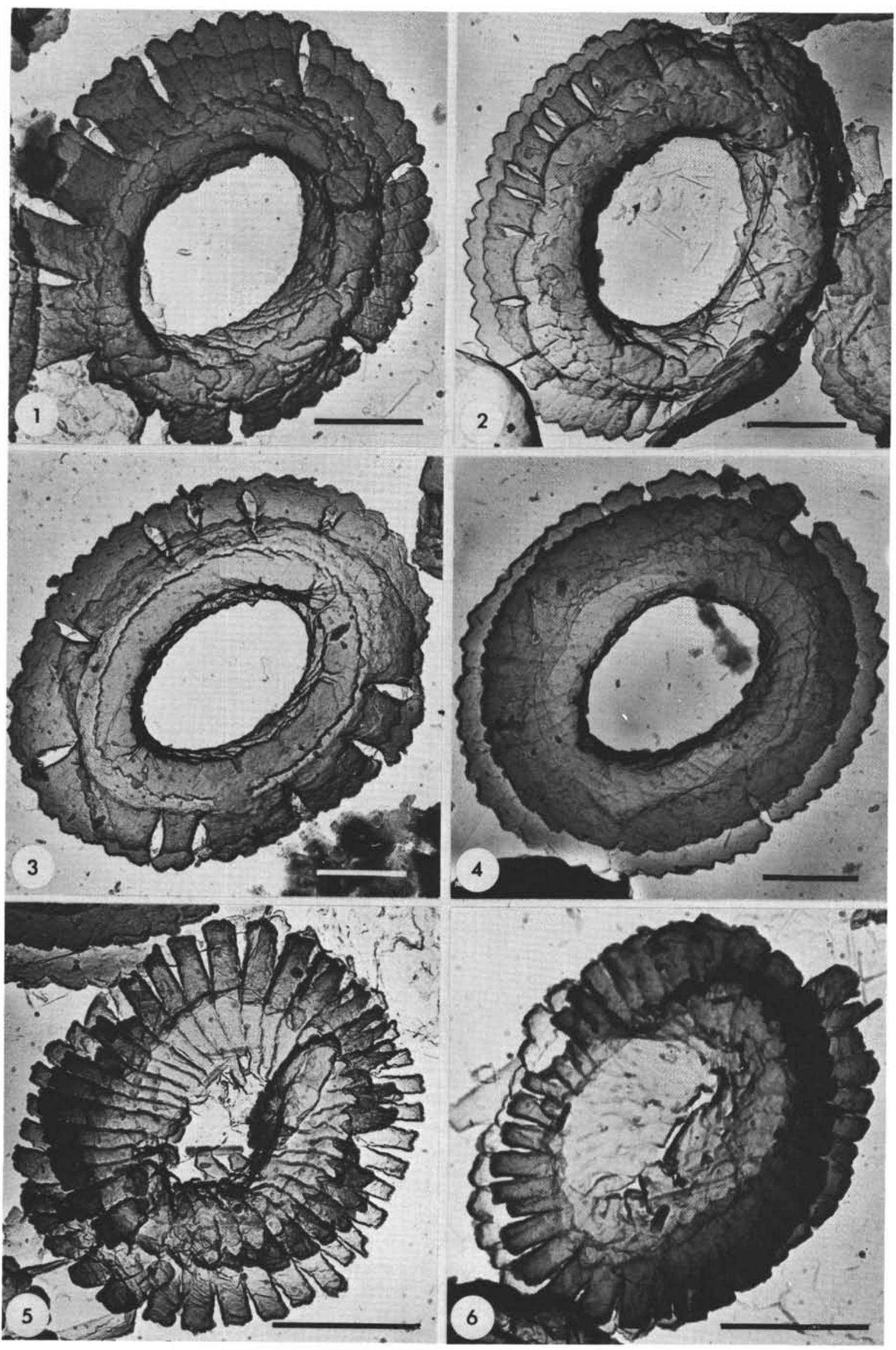


PLATE 6
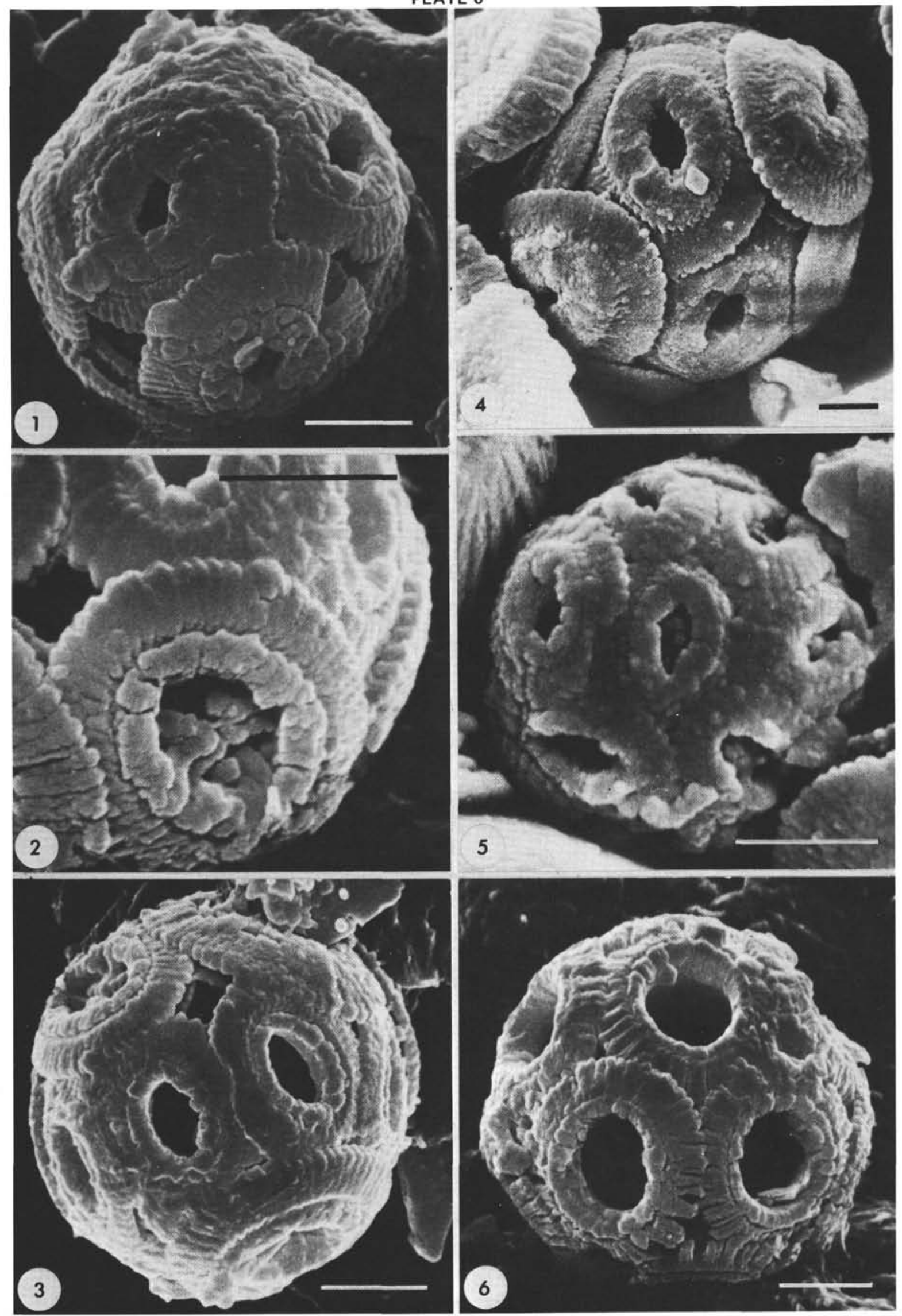


\section{PLATE 7}
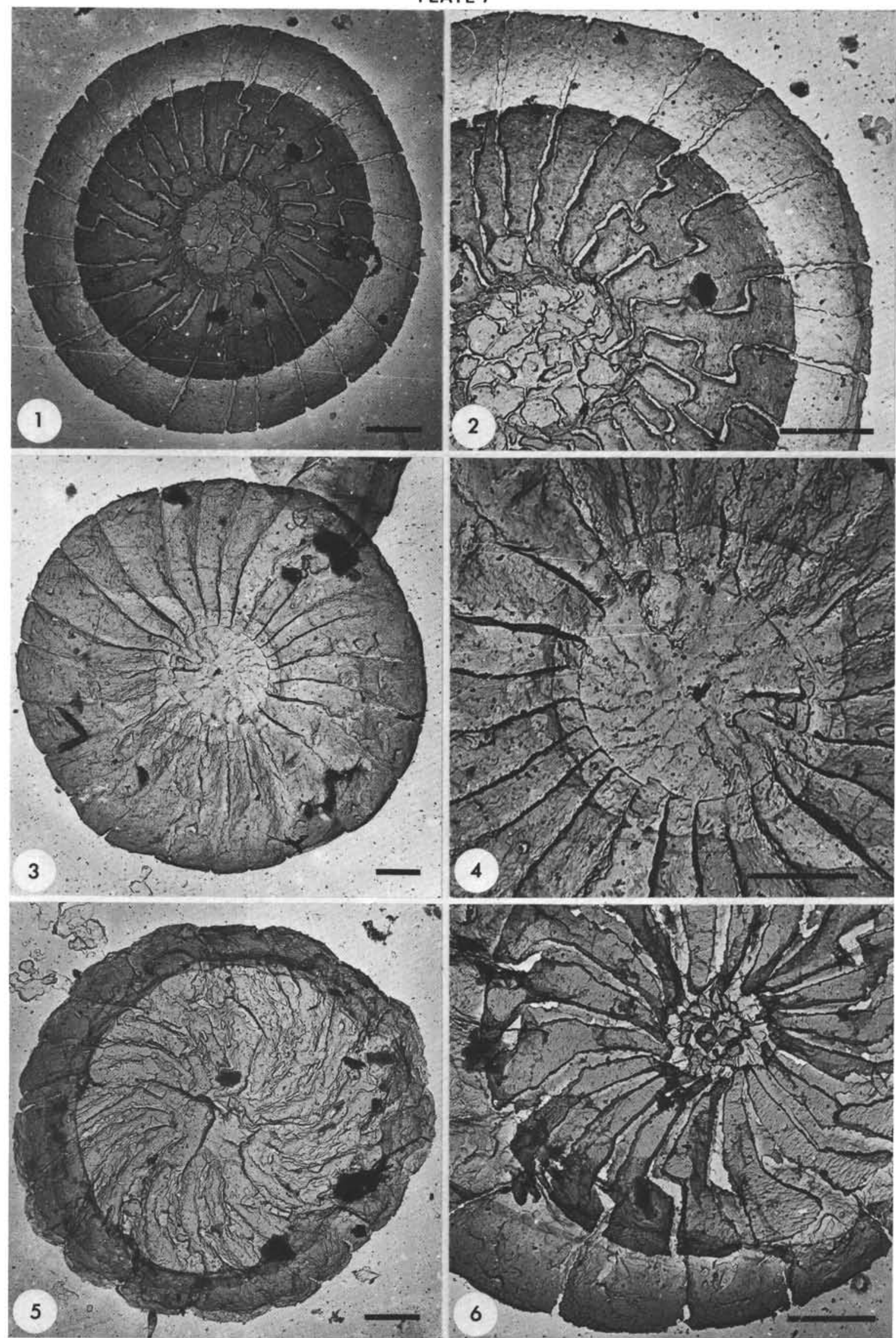
PLATE 8
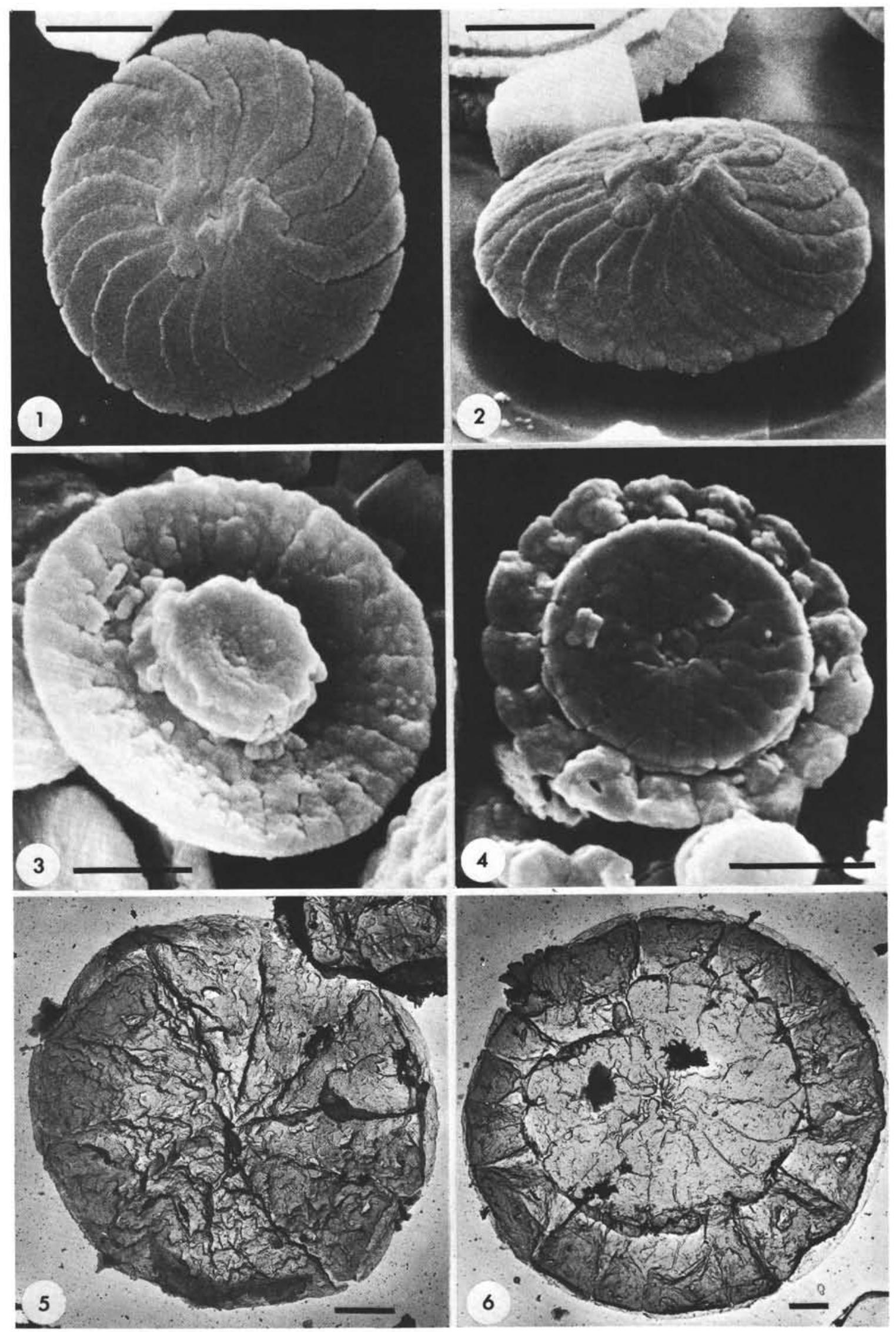
PLATE 9
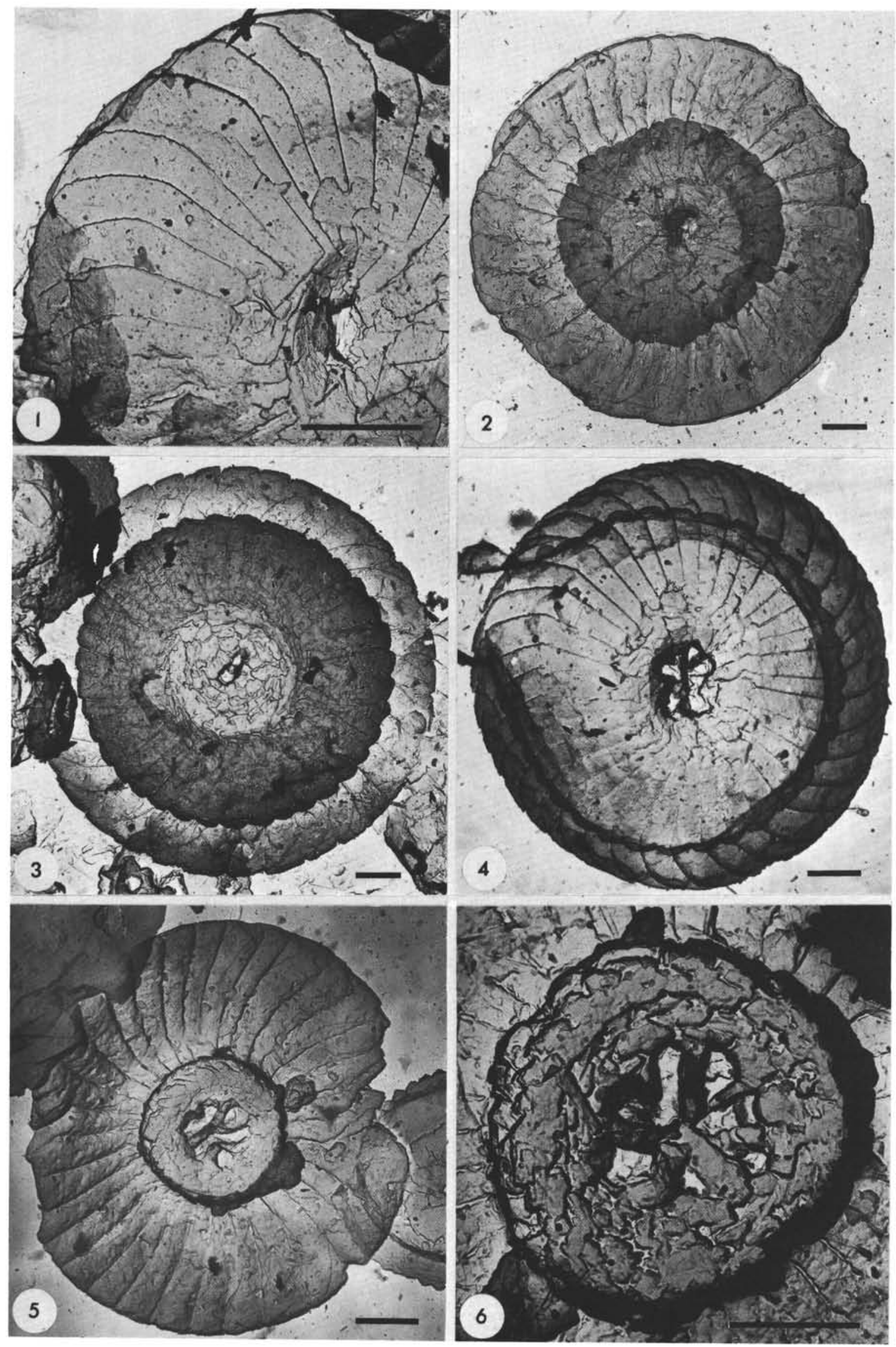
PLATE 10
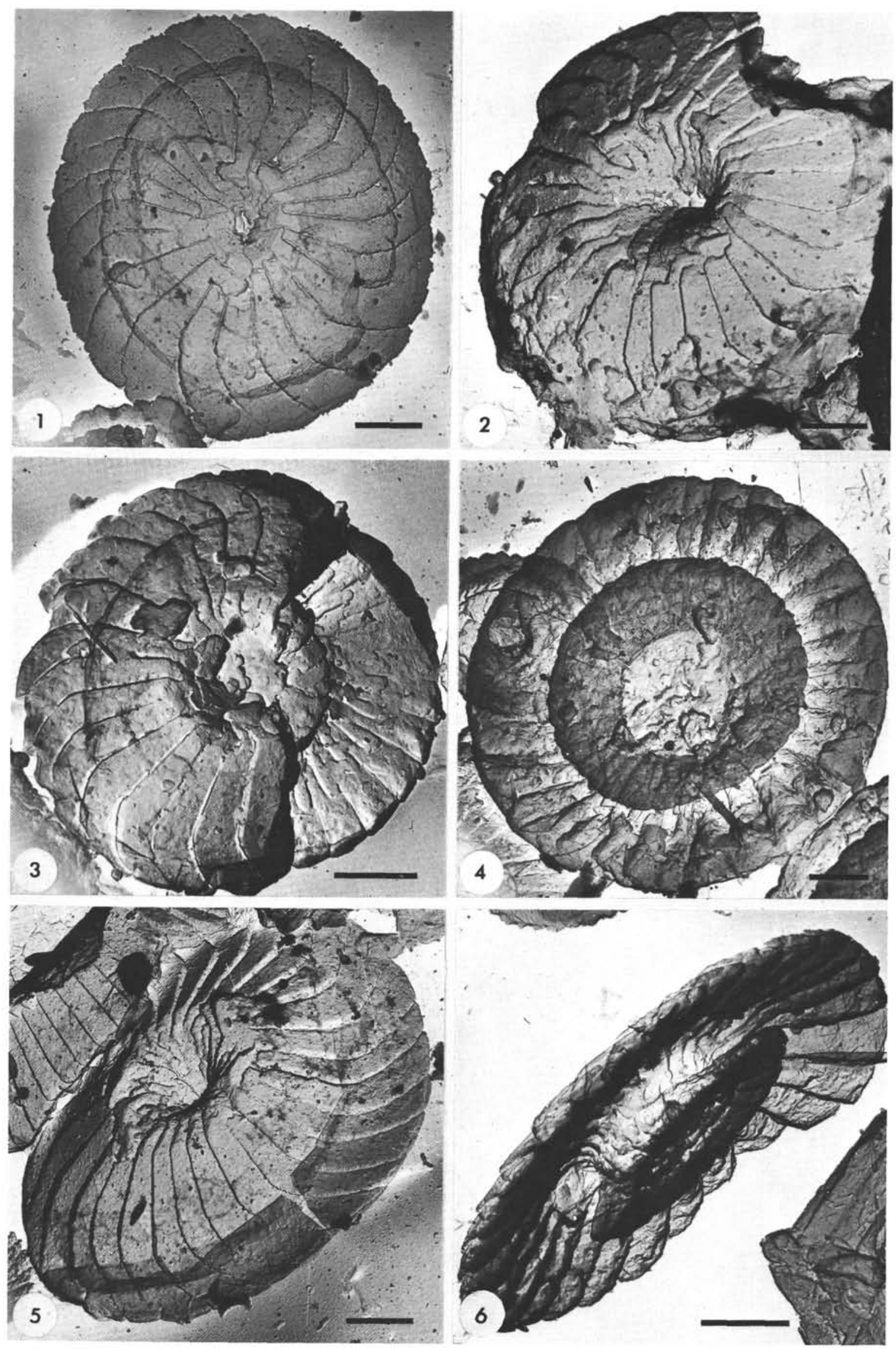


\section{PLATE 11}
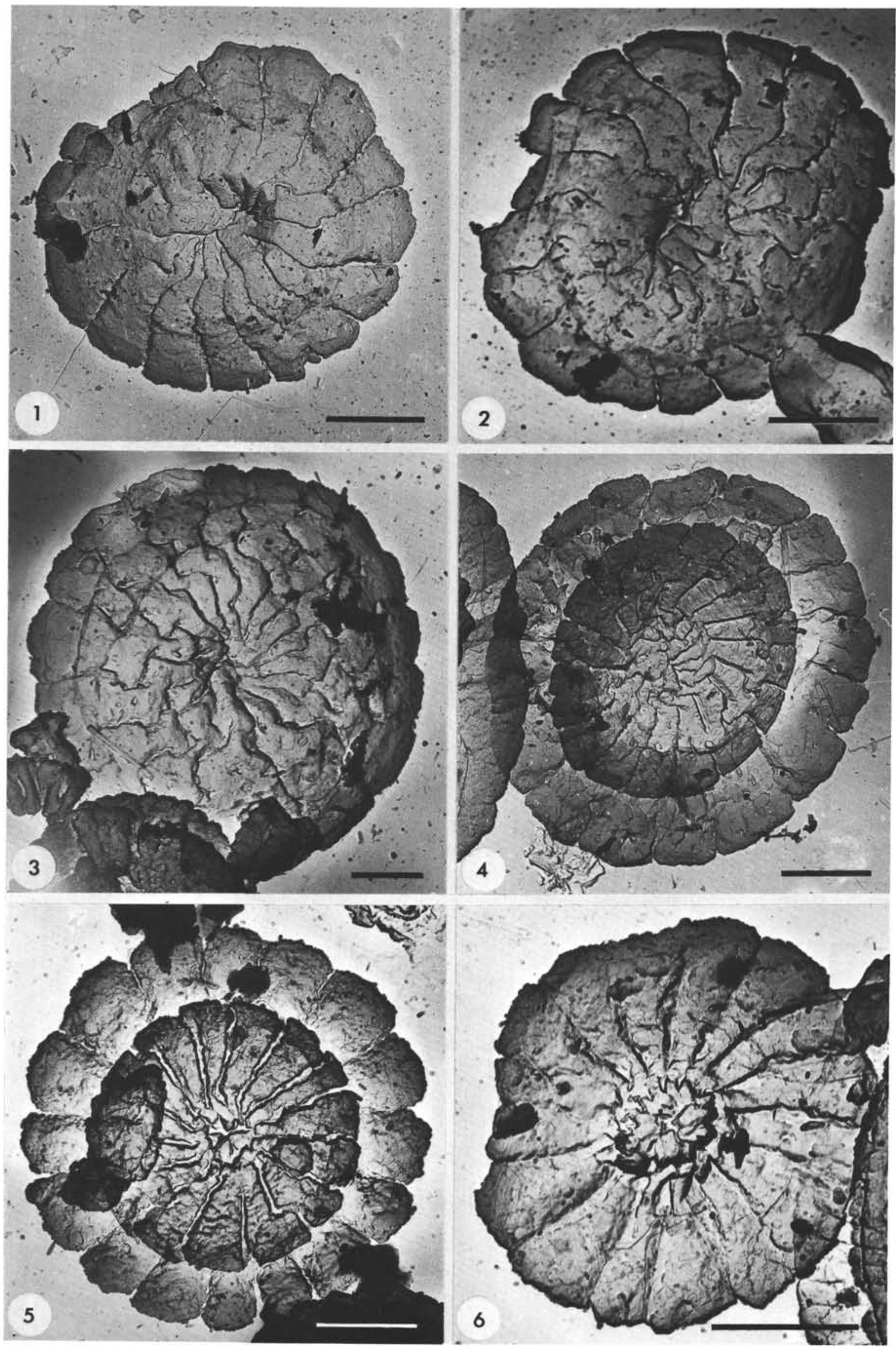
PLATE 12
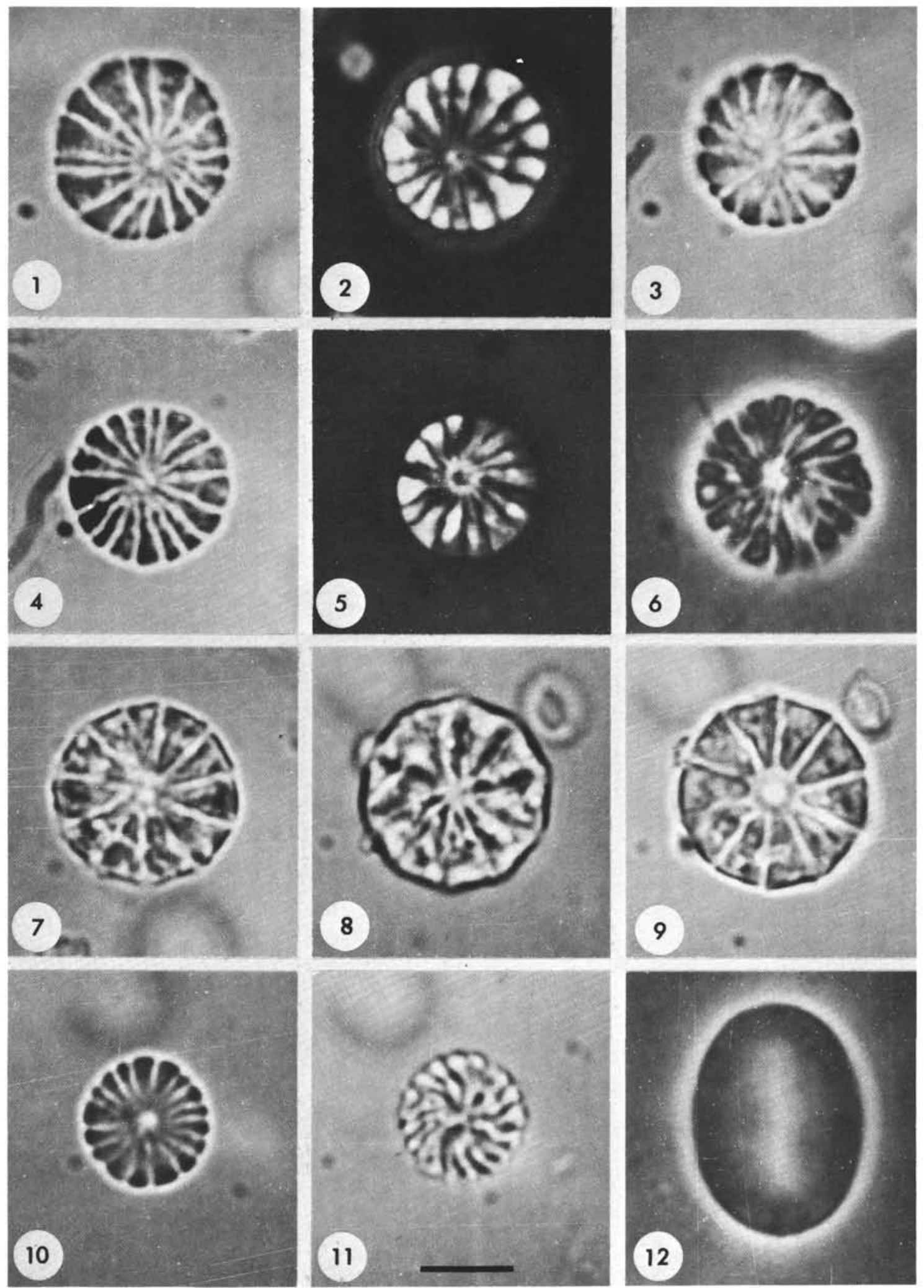
PLATE 13
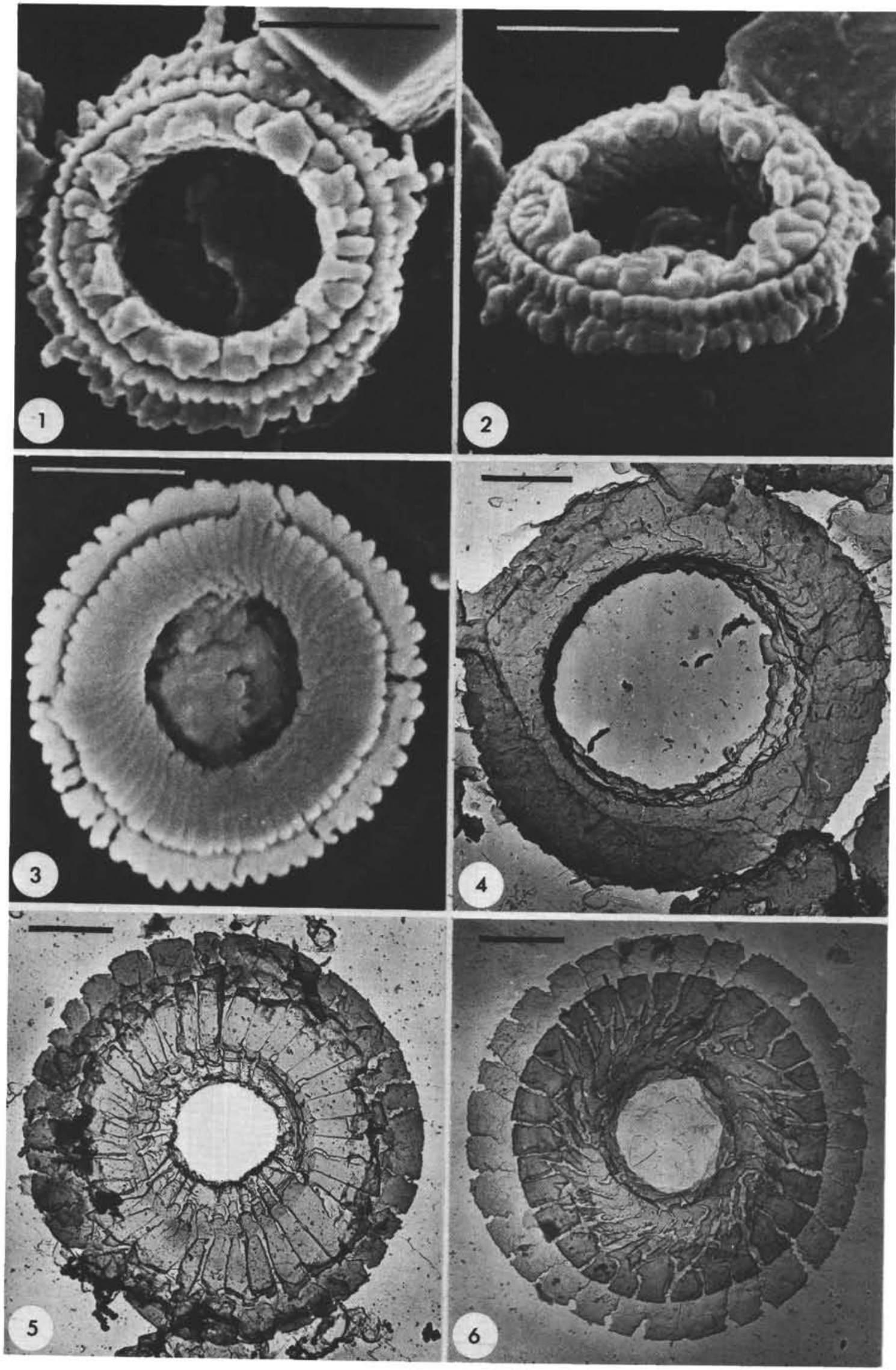


\section{PLATE 14}
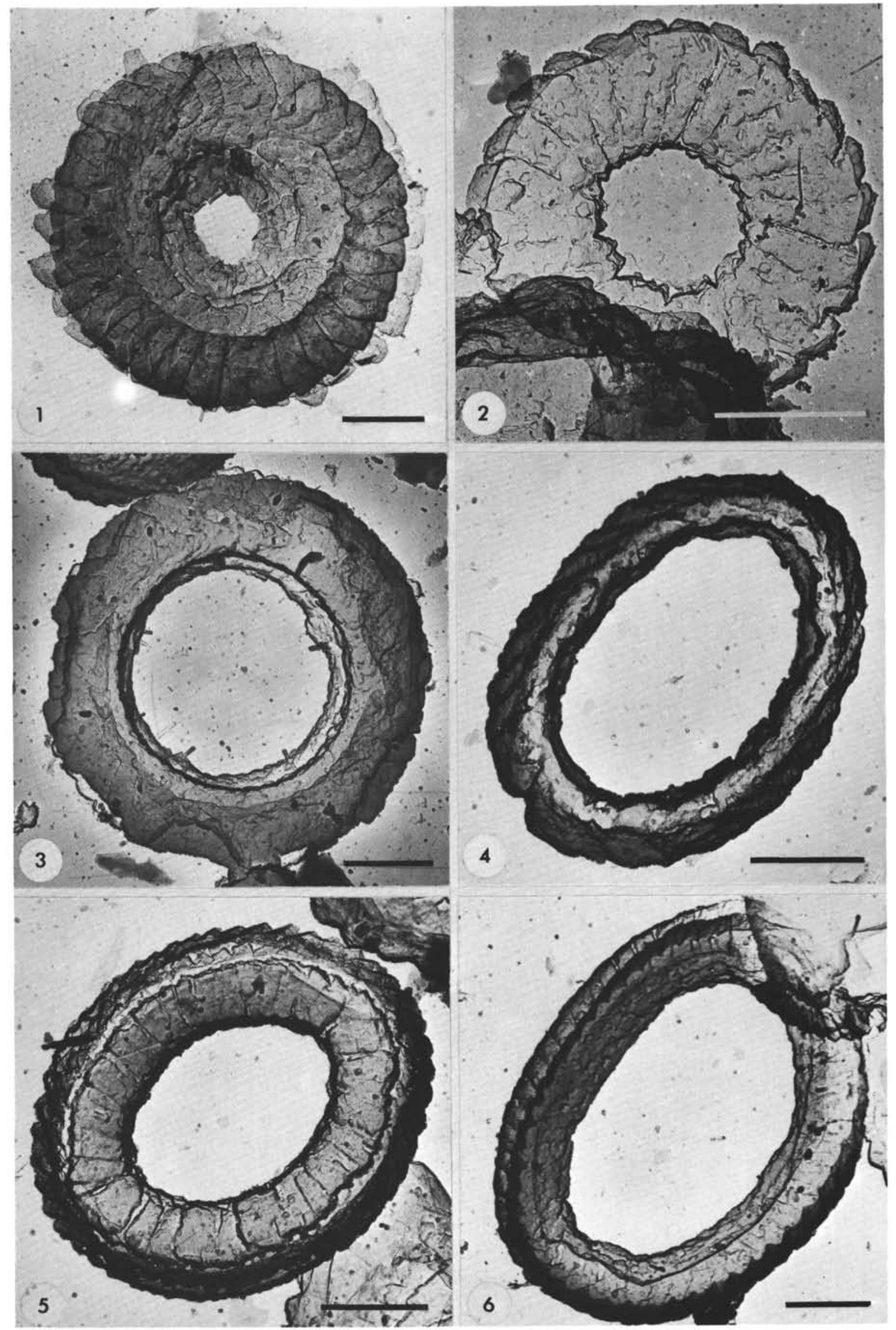
Plate 15

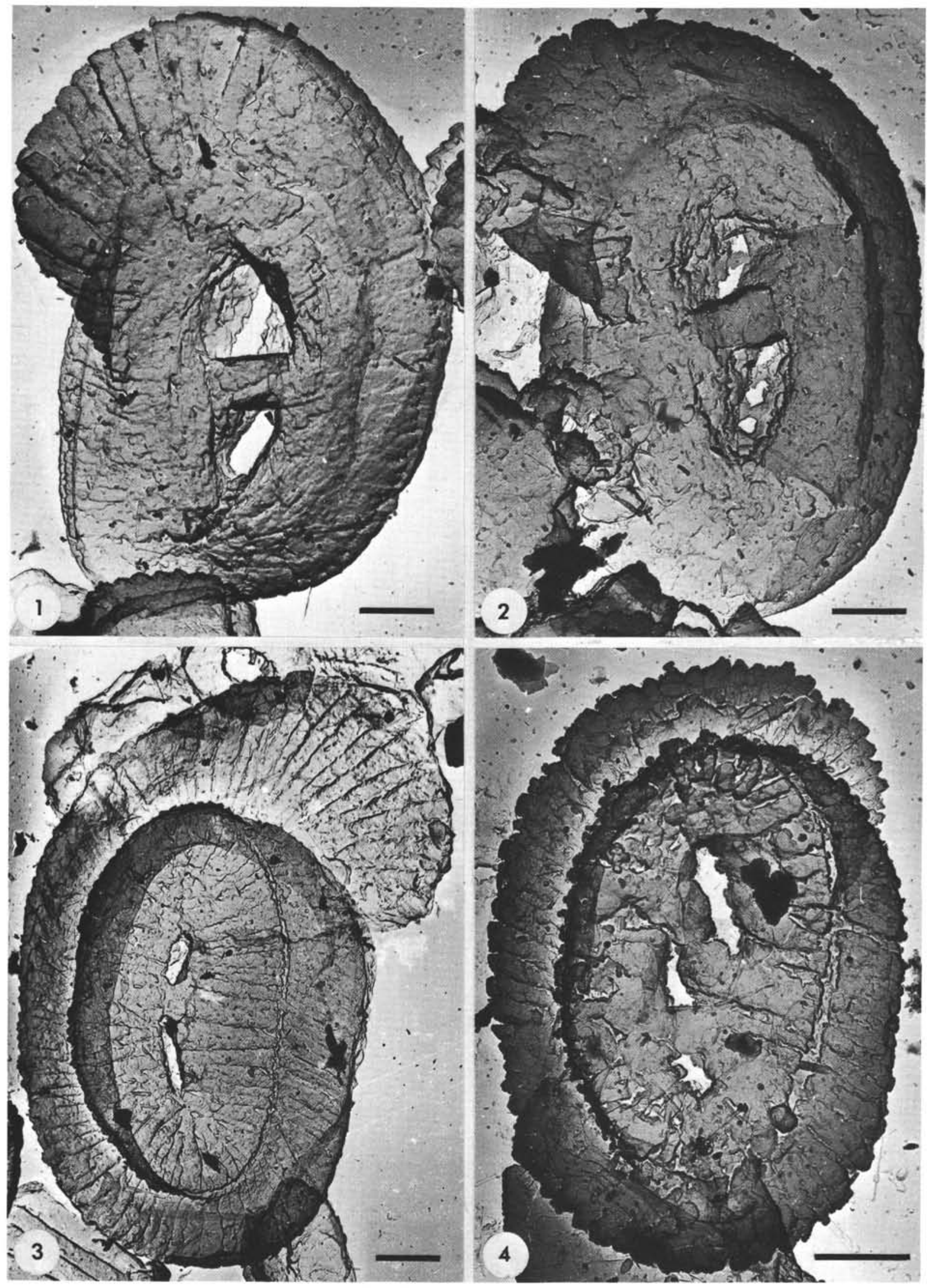


PLATE 16
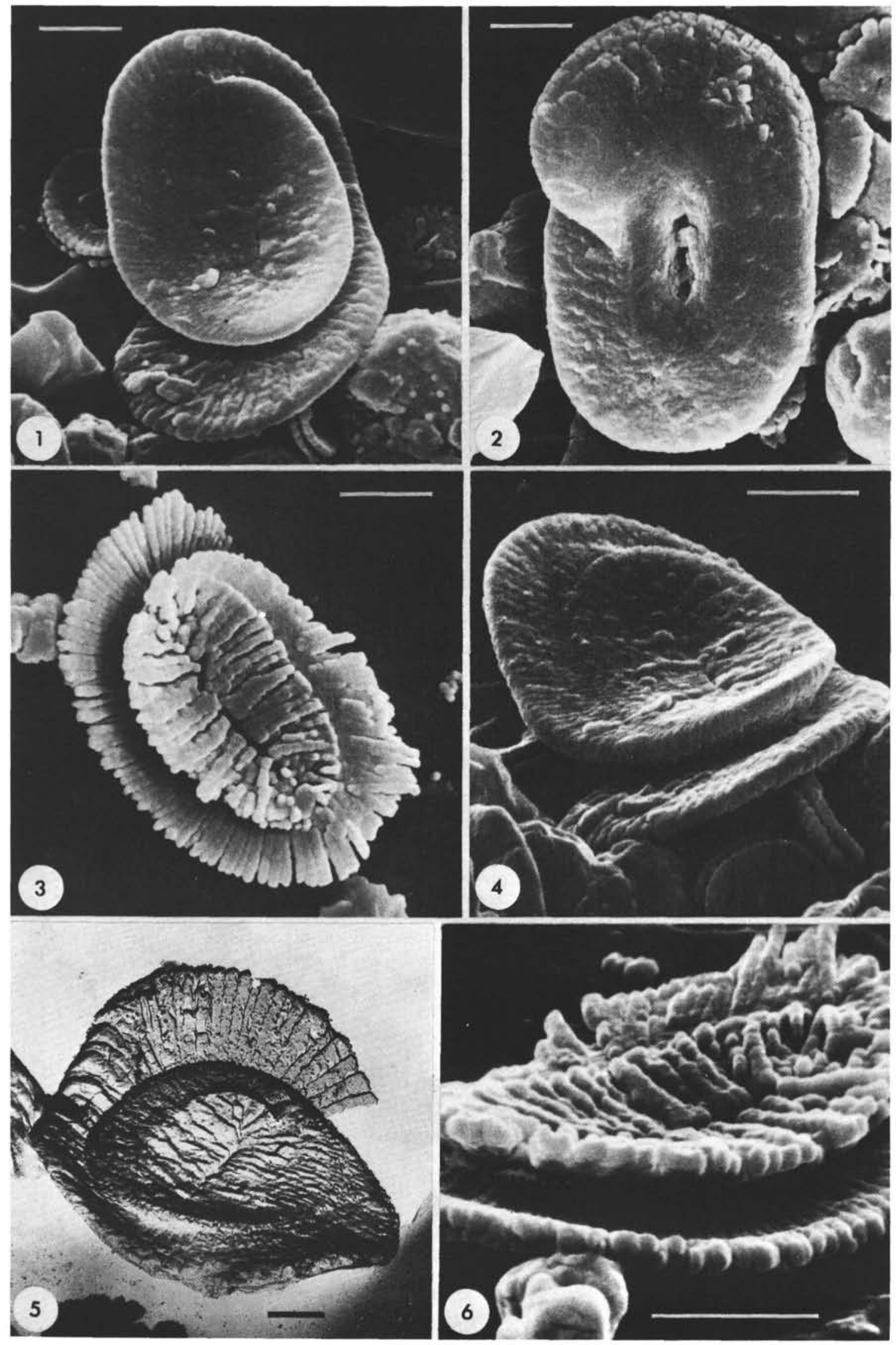
PLATE 17

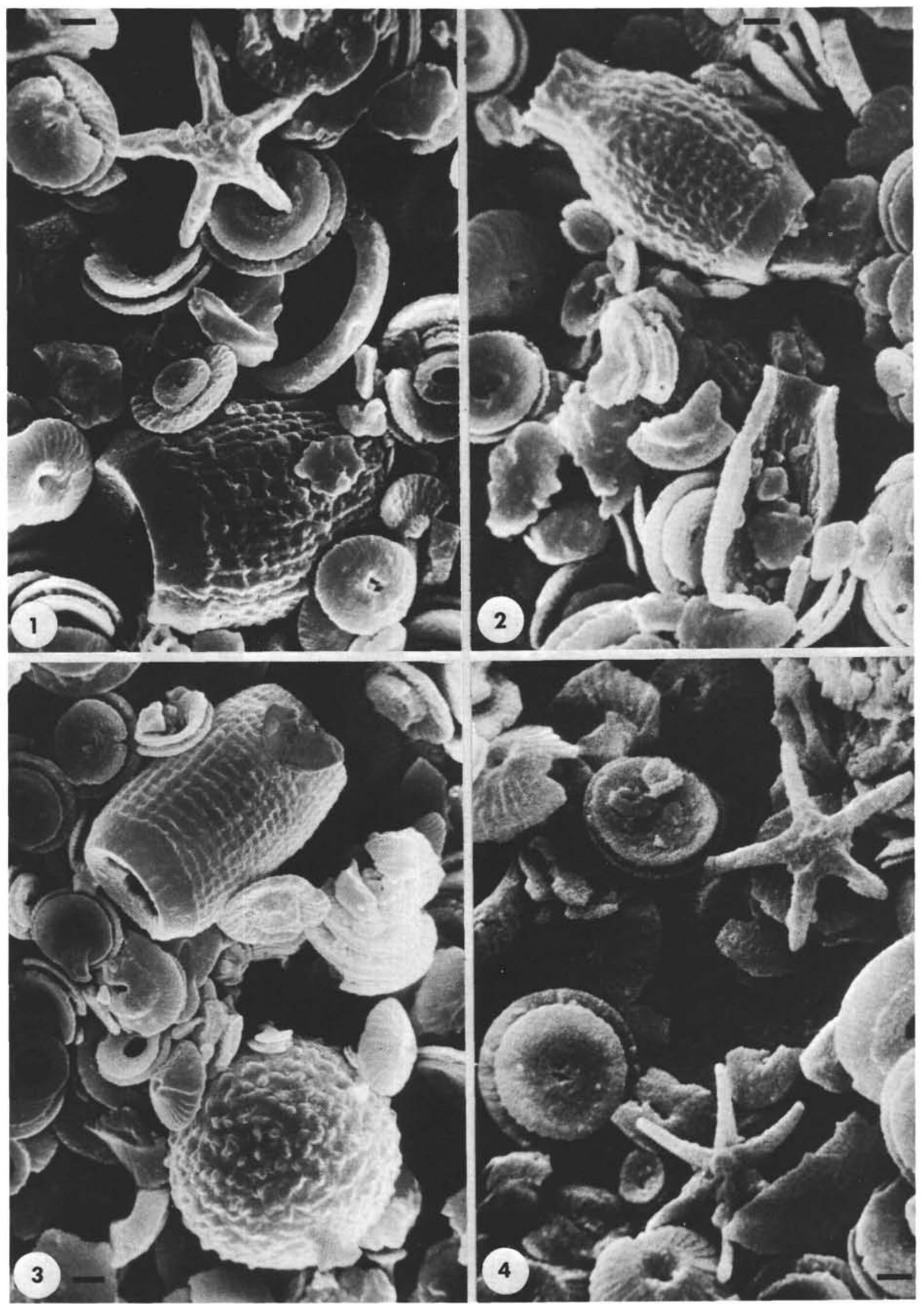


PLATE 18
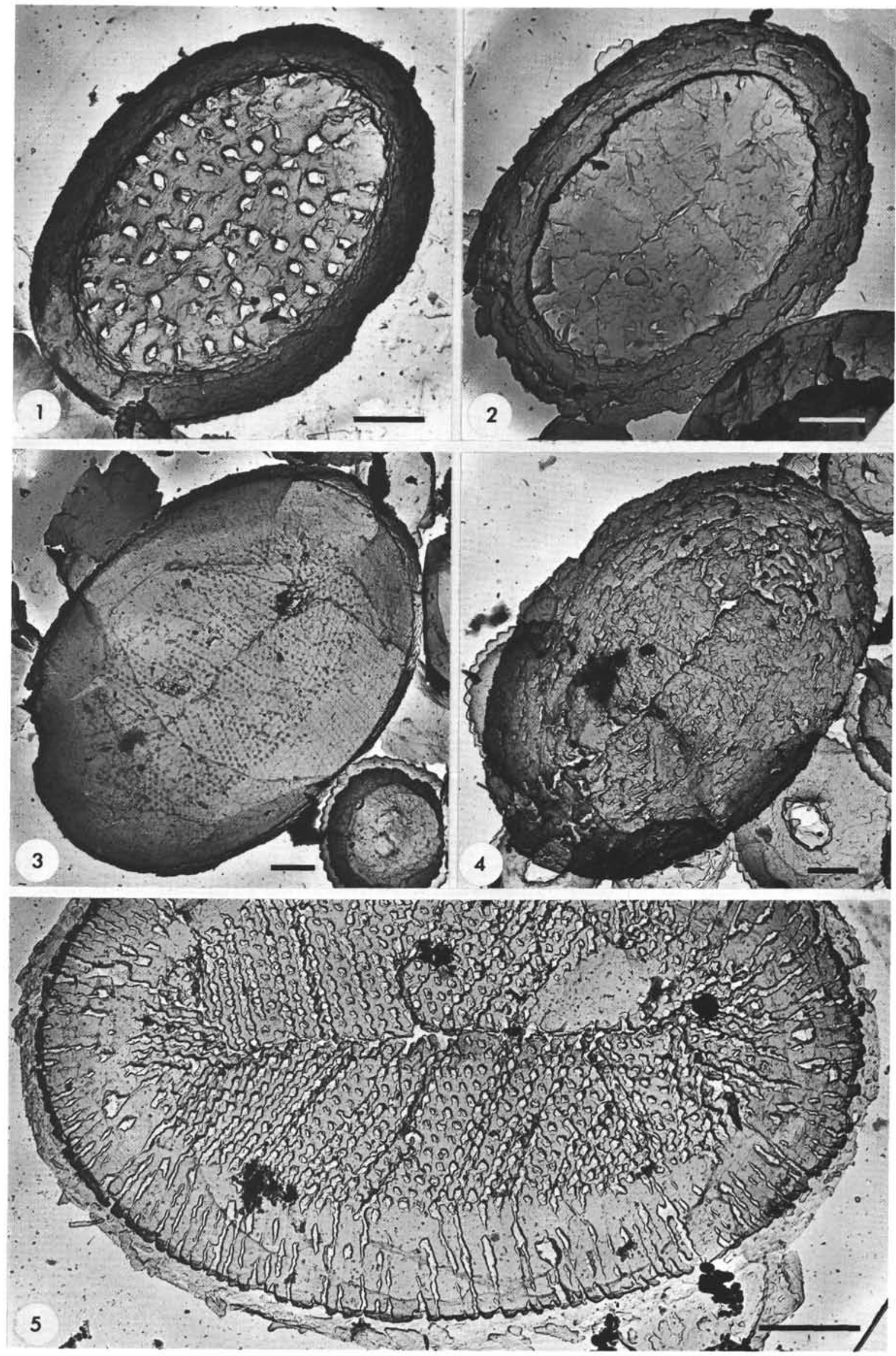
PLATE 19
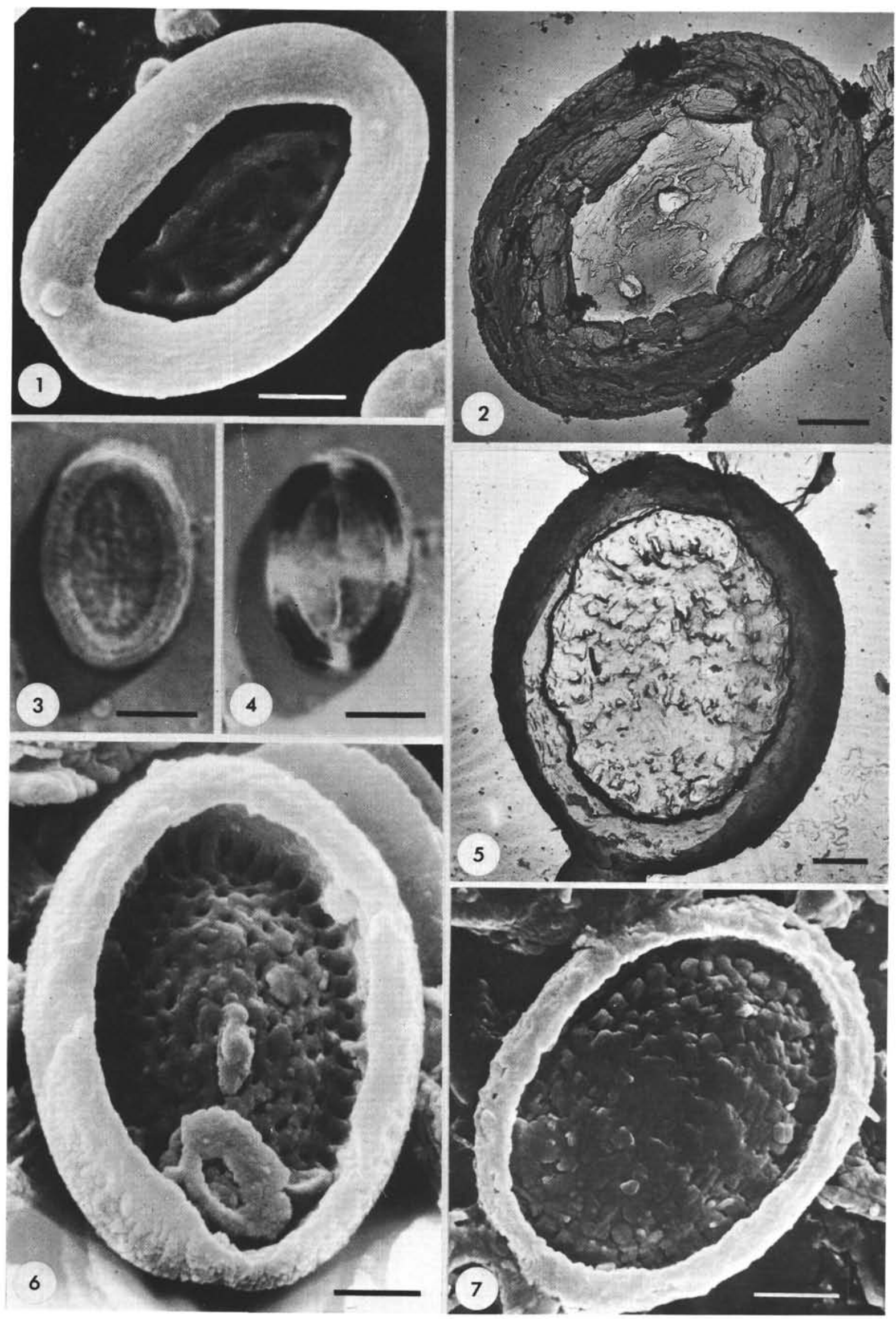
PLATE 20
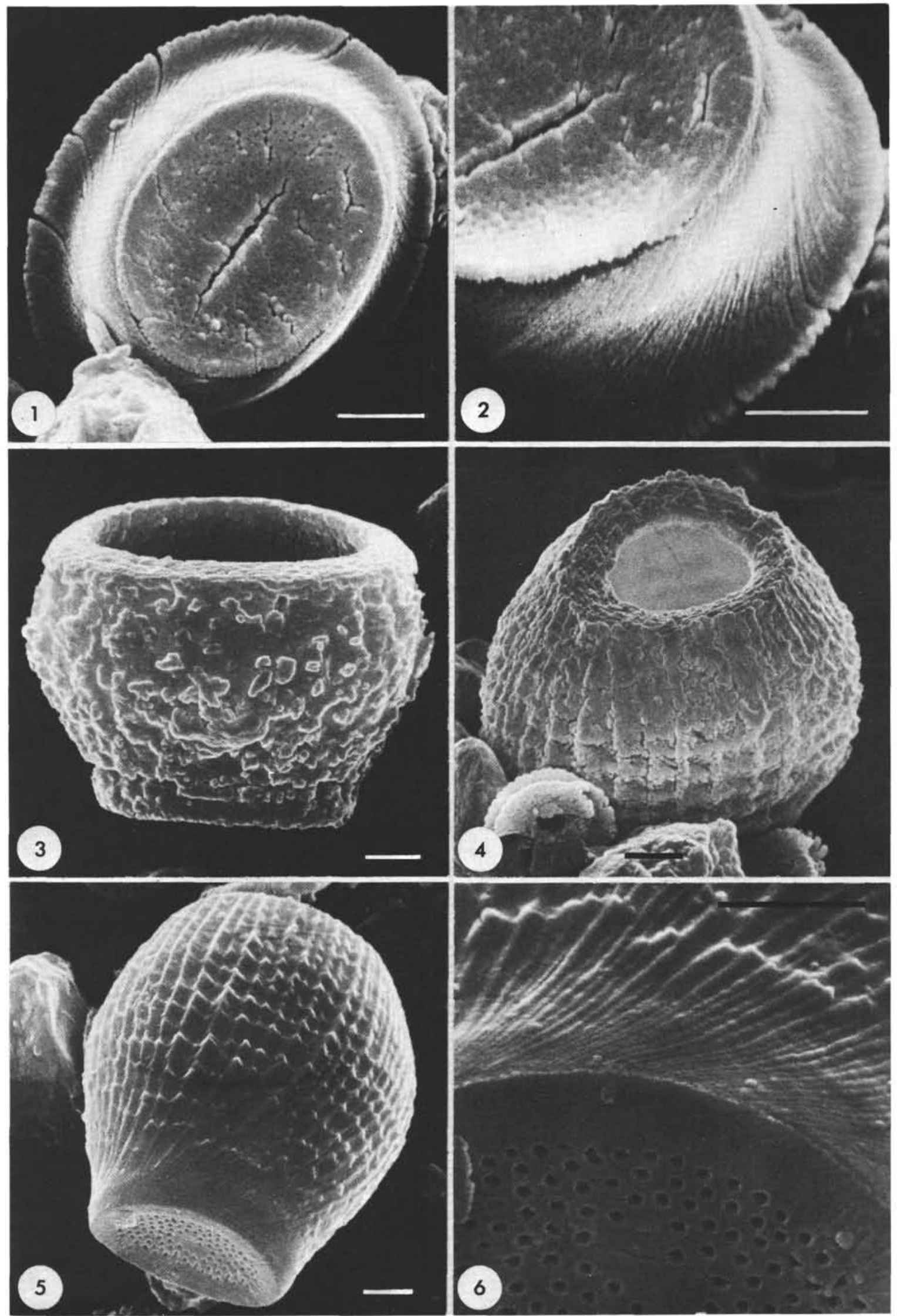
PLATE 21

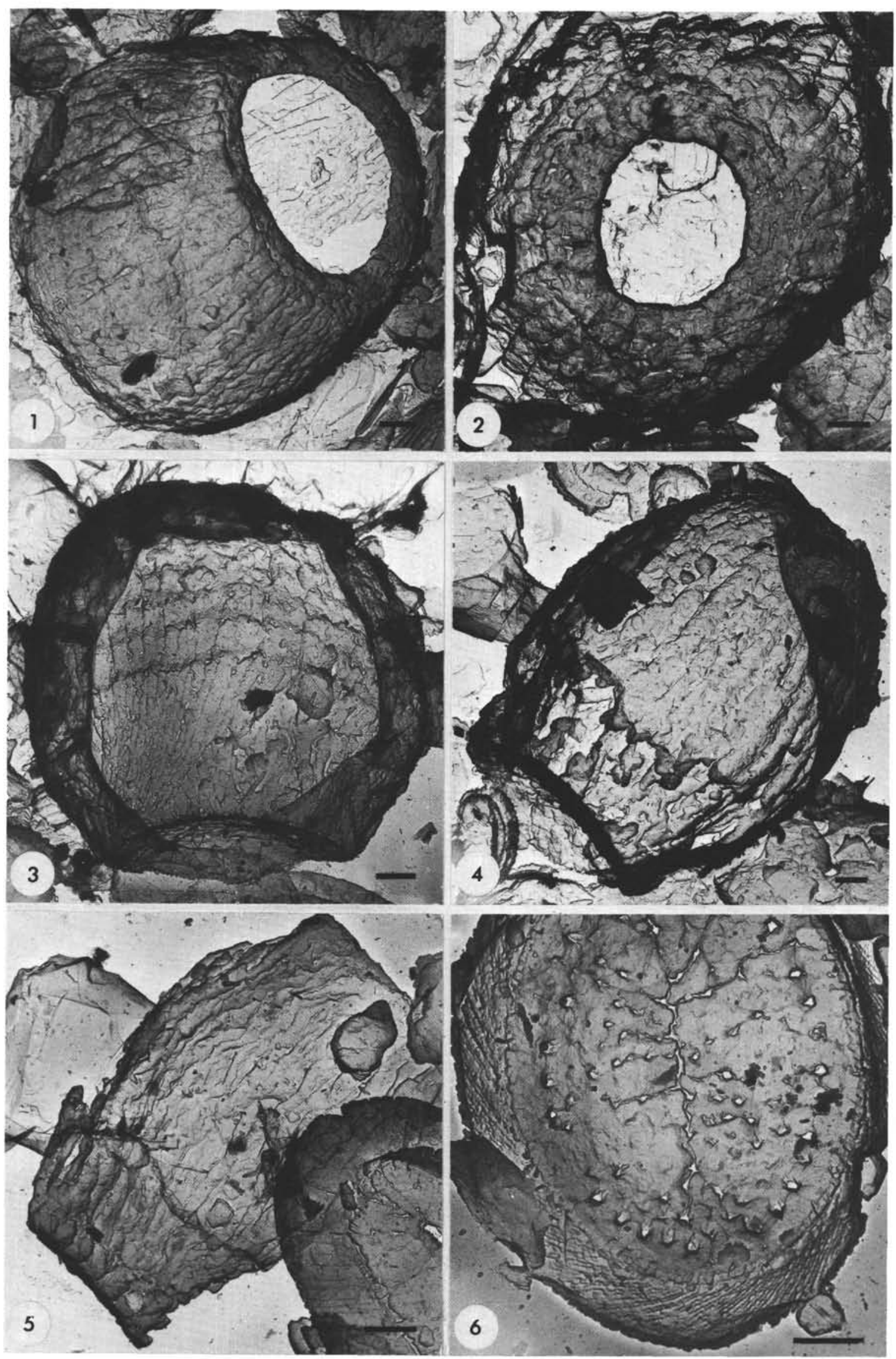


PLATE 22
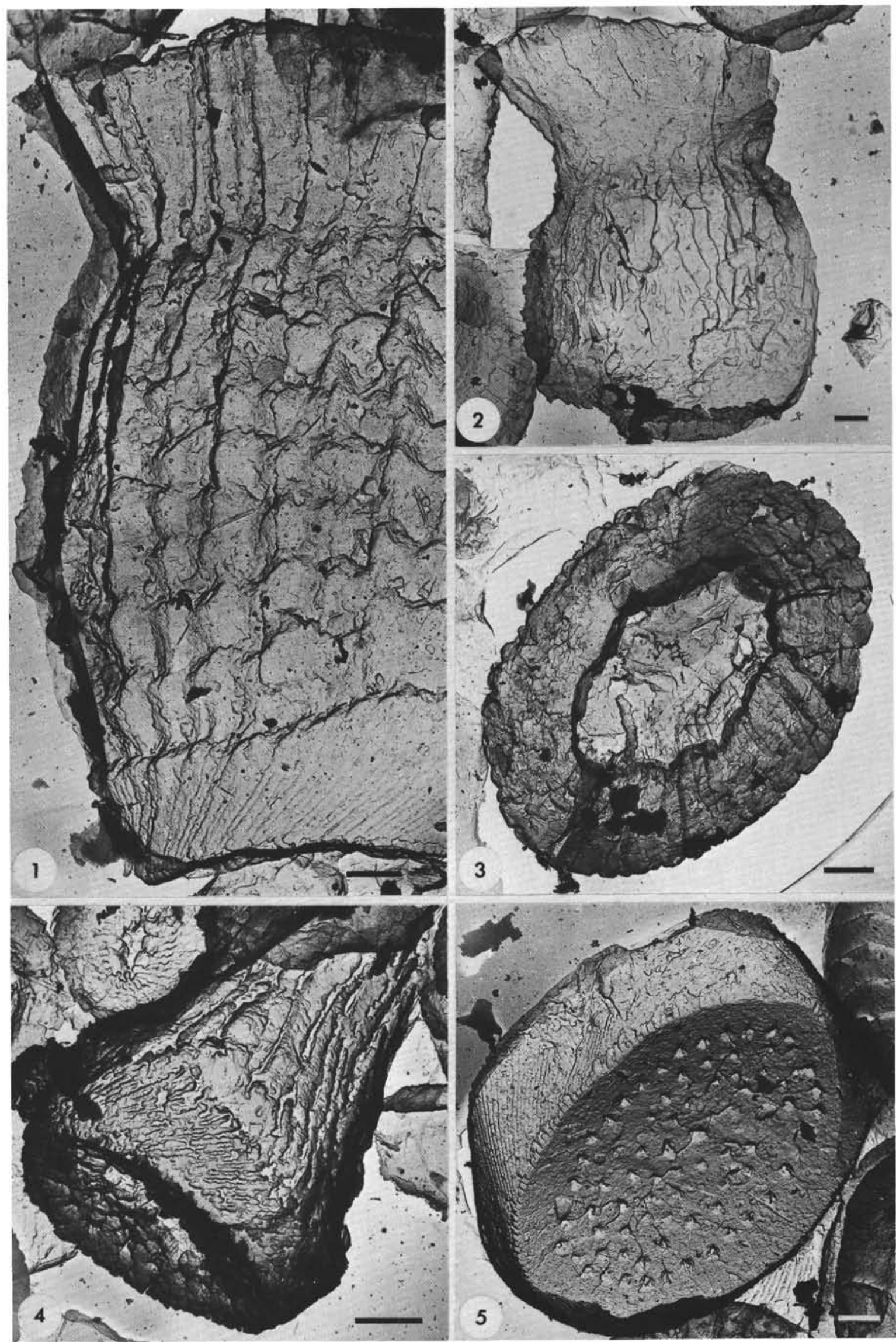


\section{PLATE 23}
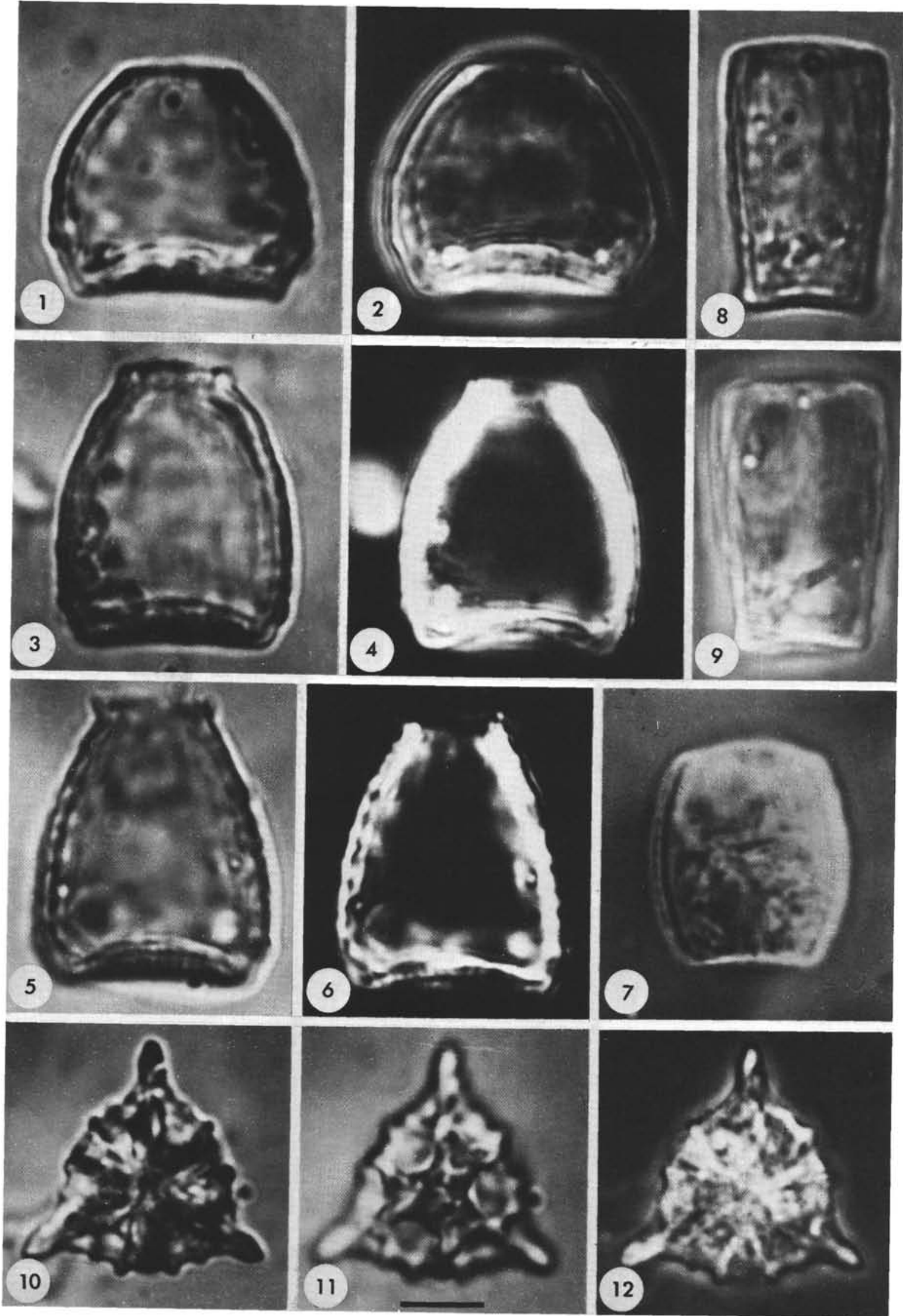
PLATE 24

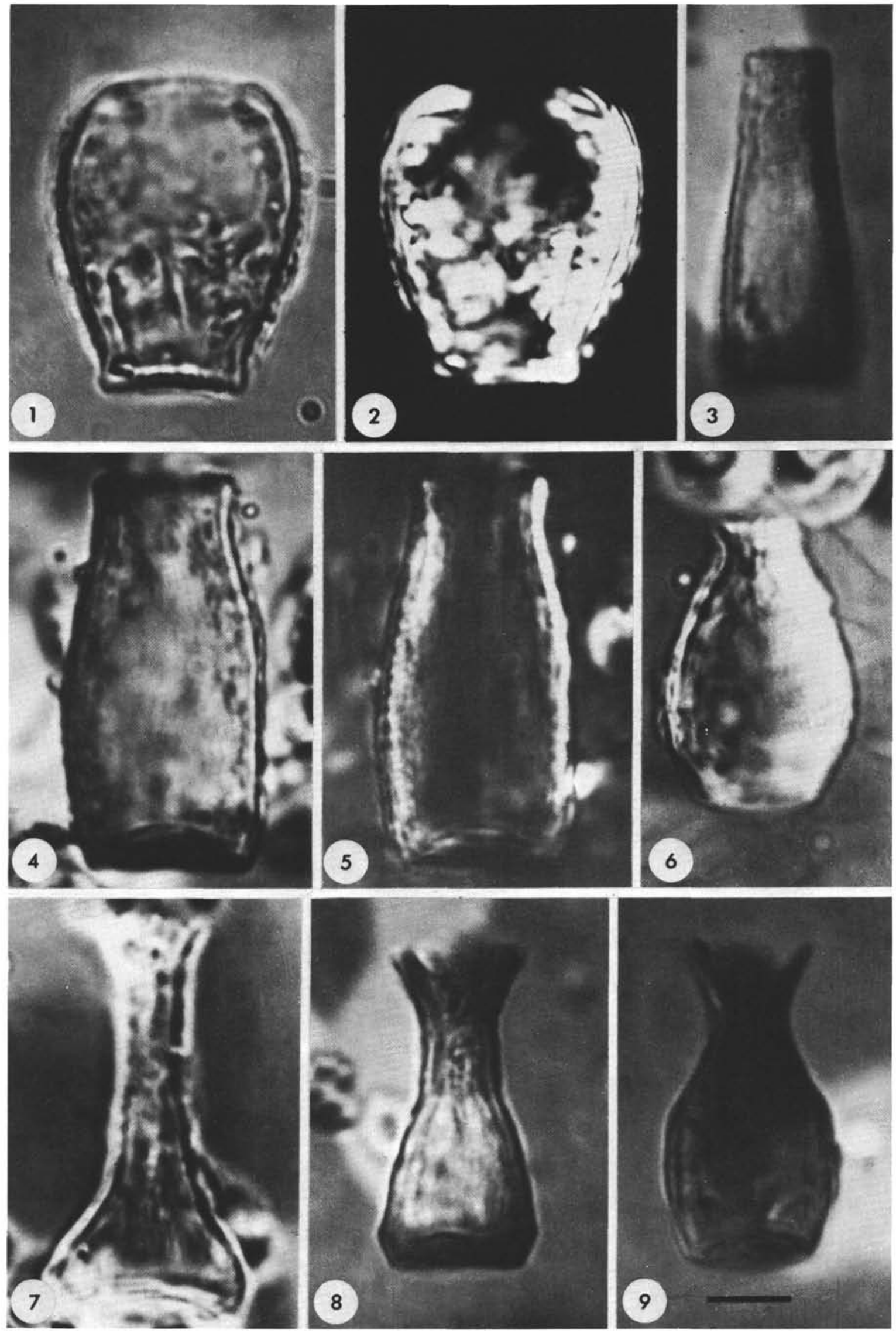


PLATE 25

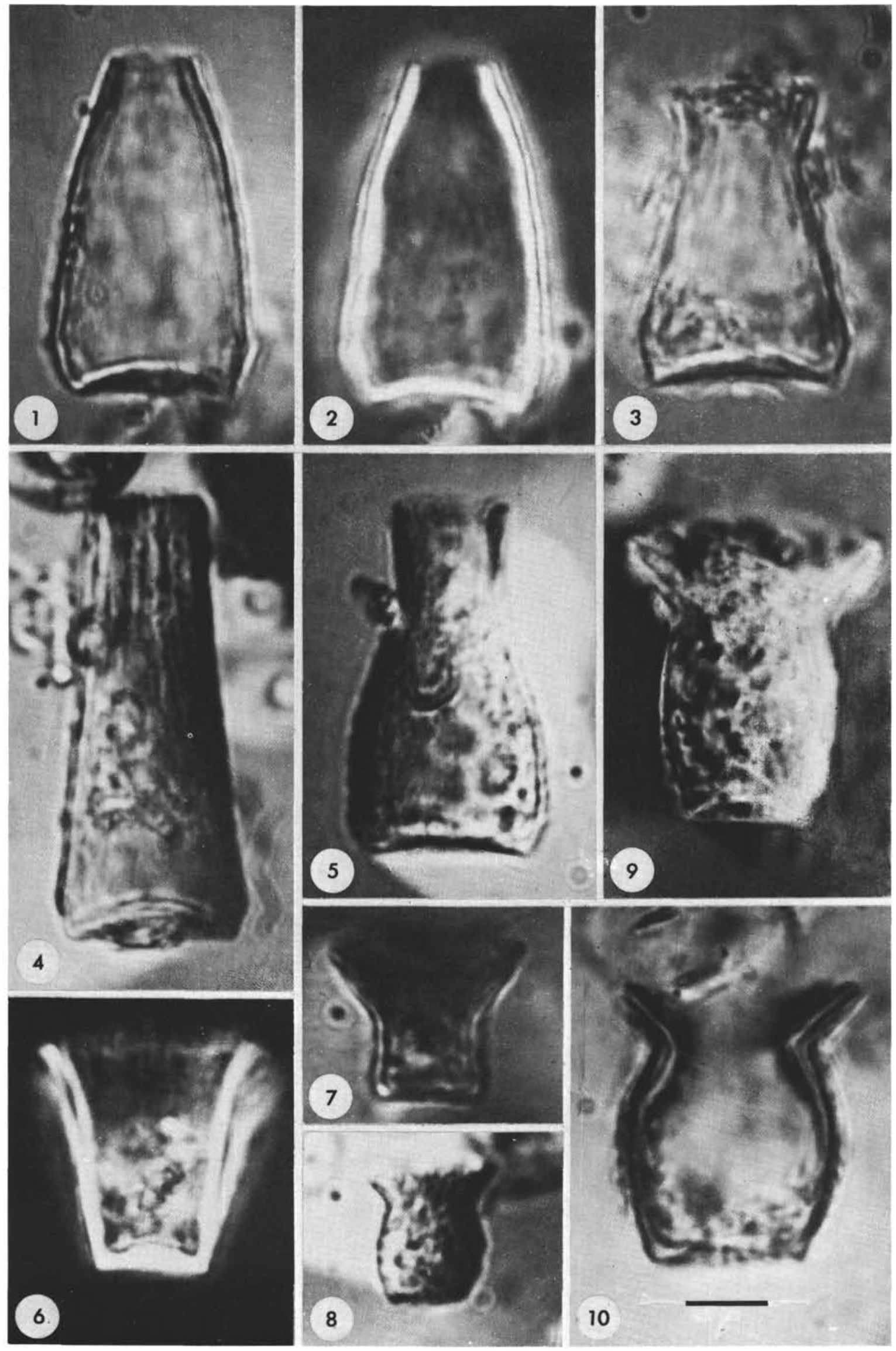


PLATE 26

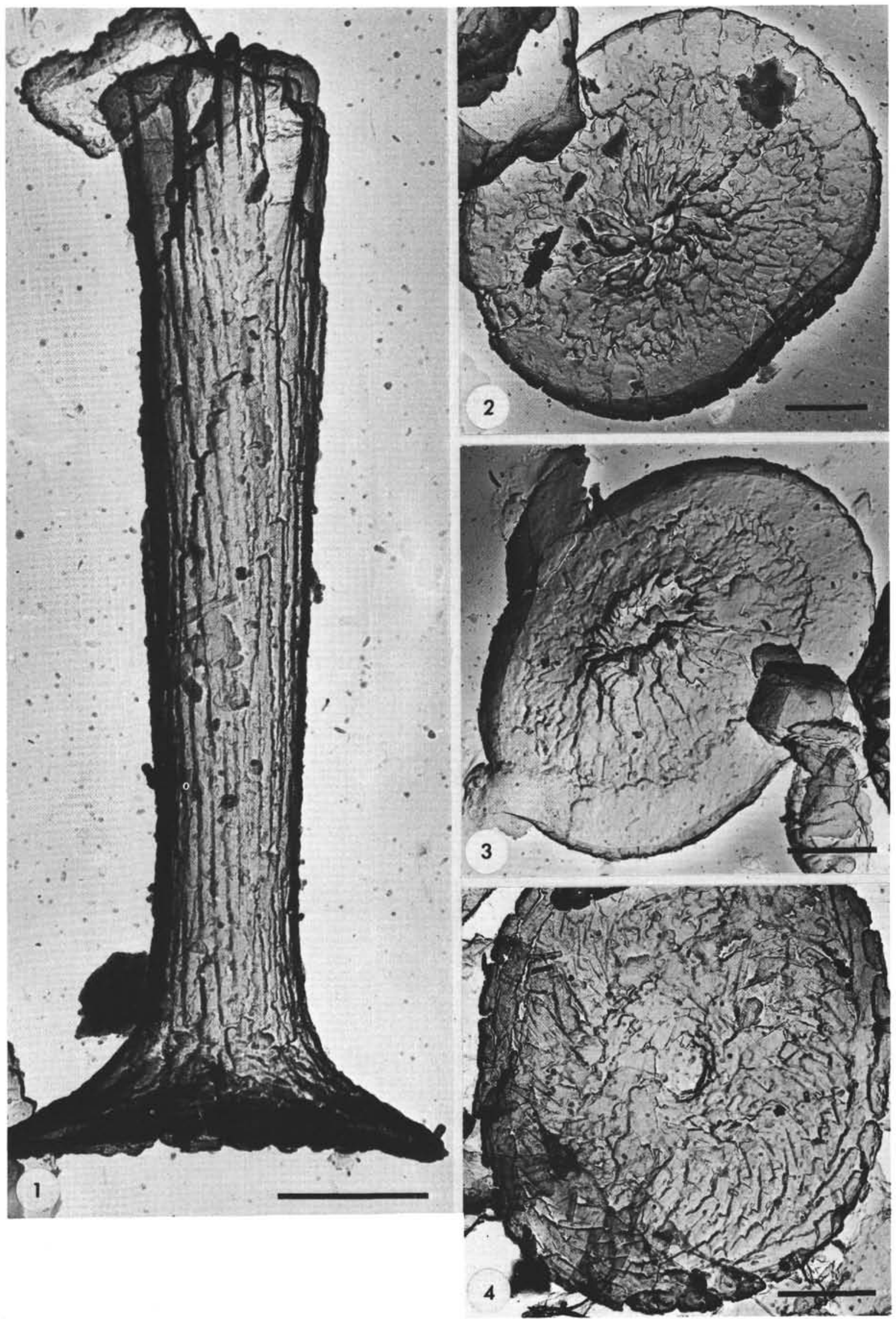


PLATE 27
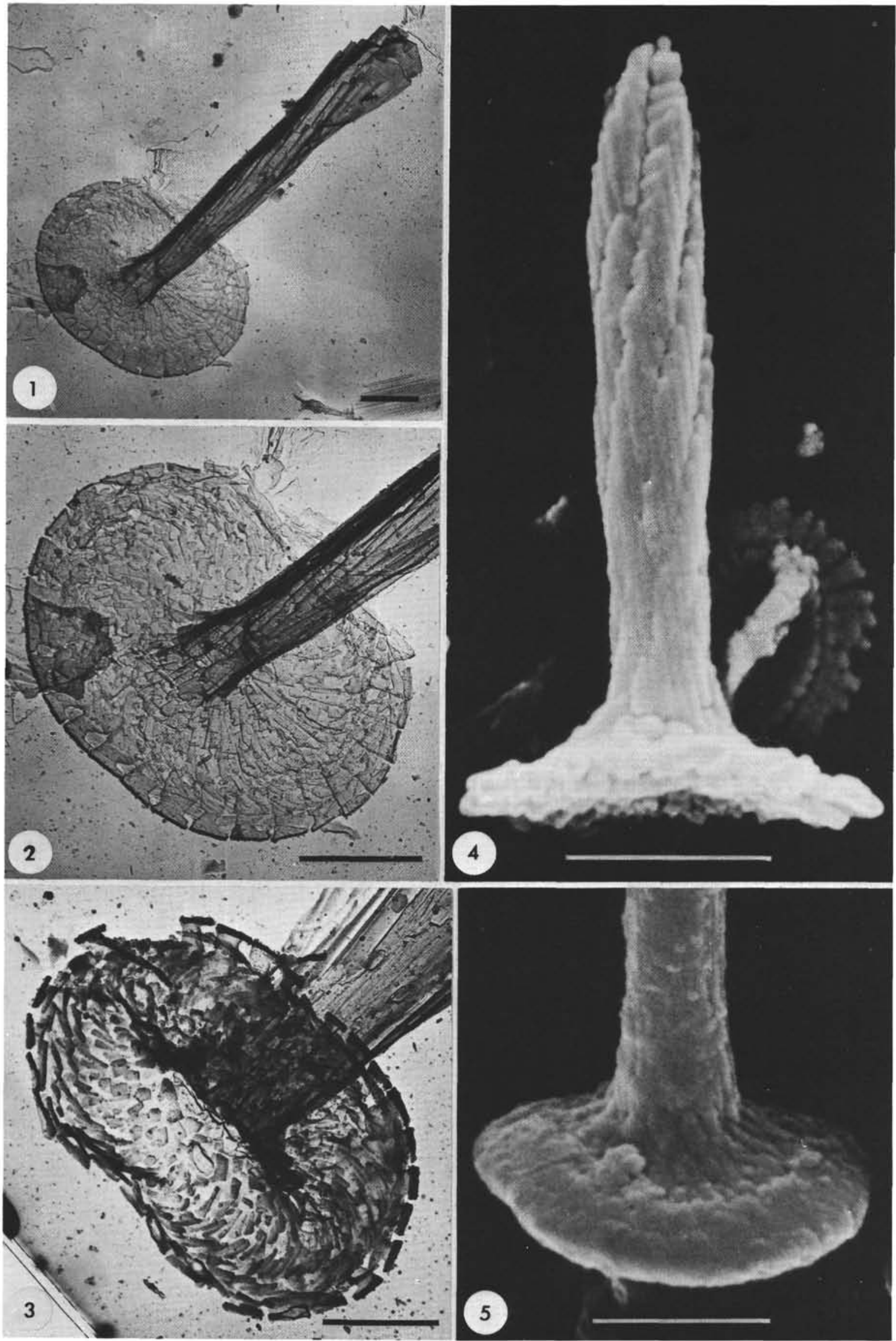
PLATE 28
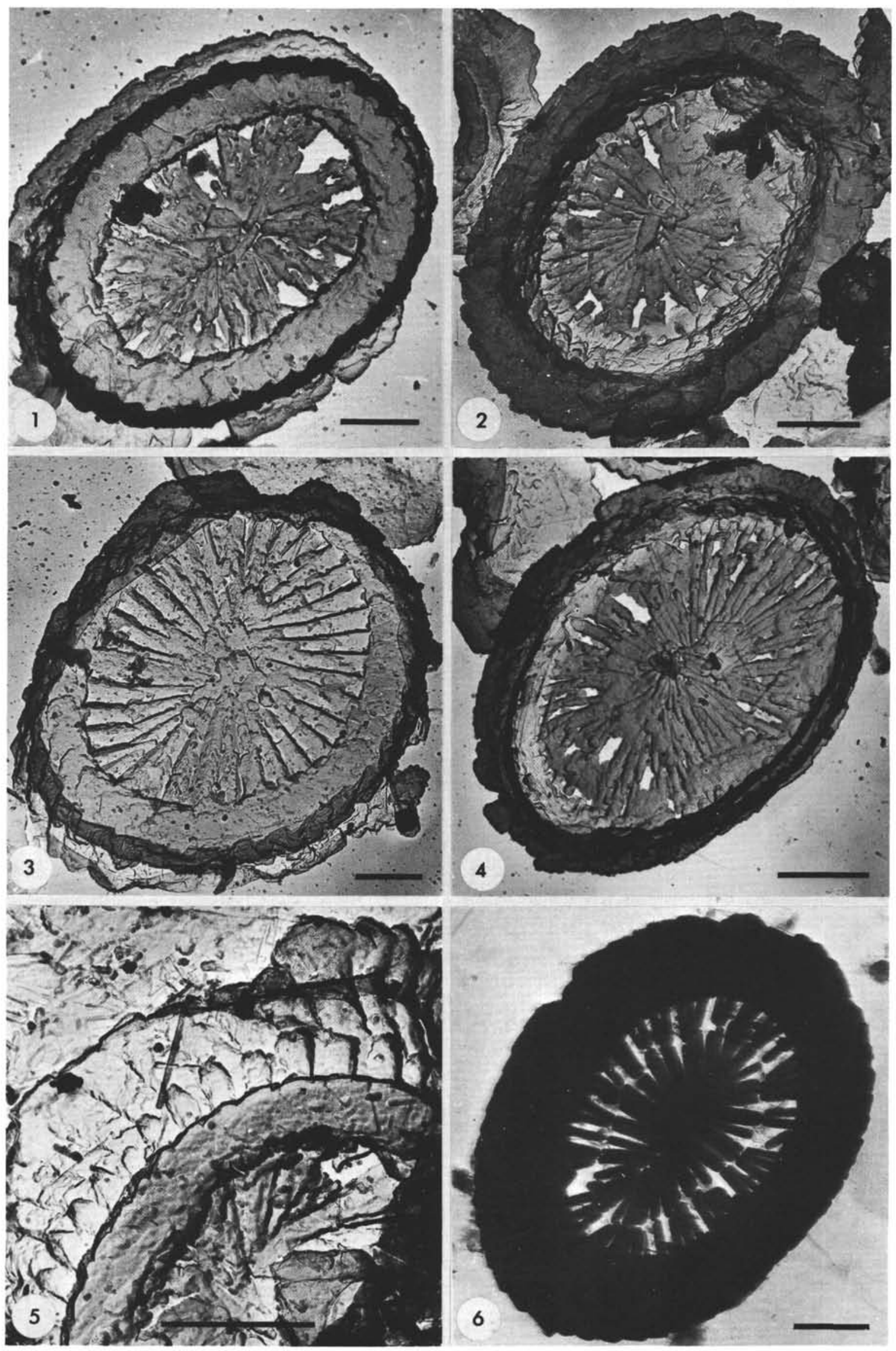
PLATE 29
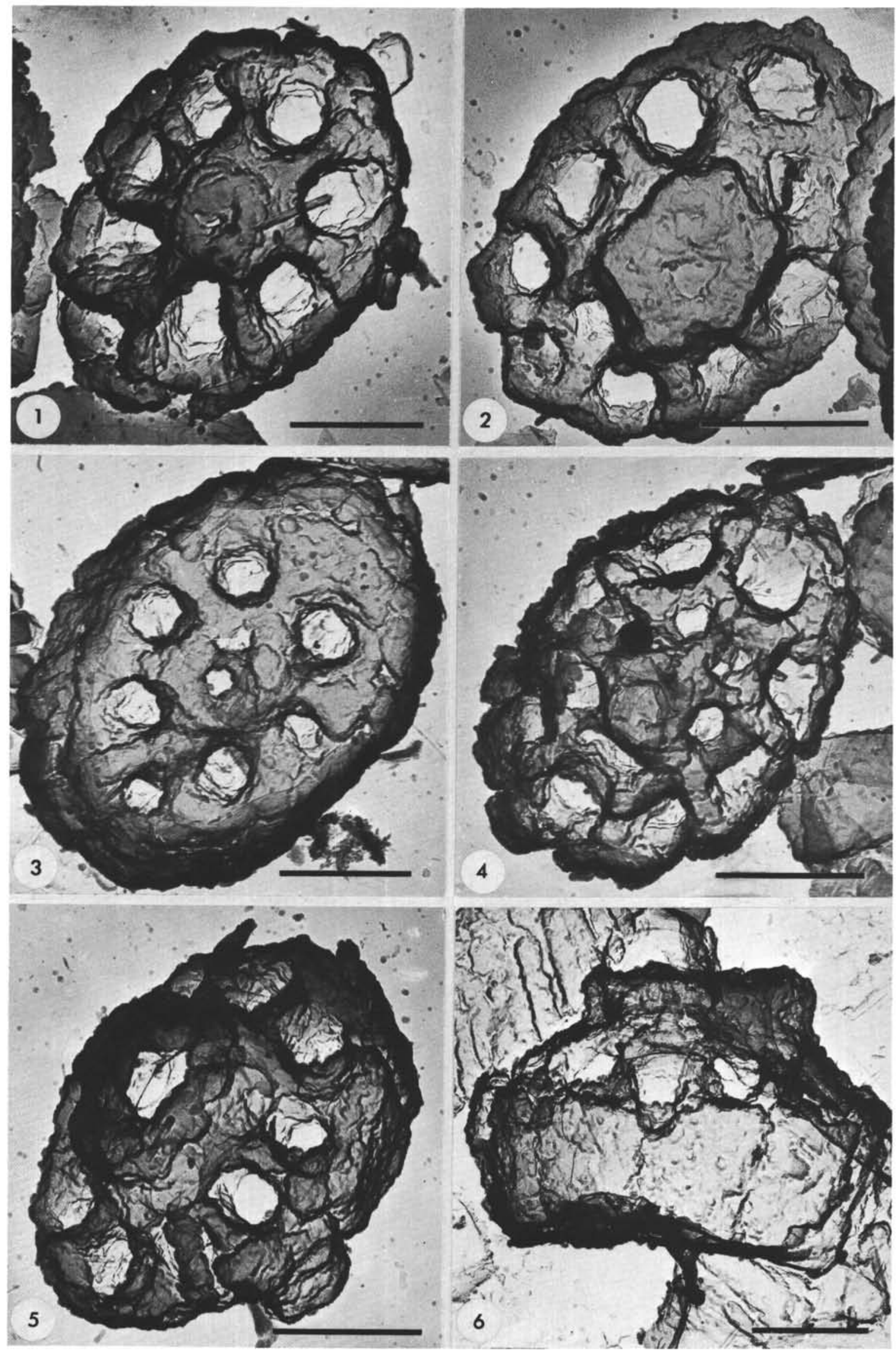
PLATE 30
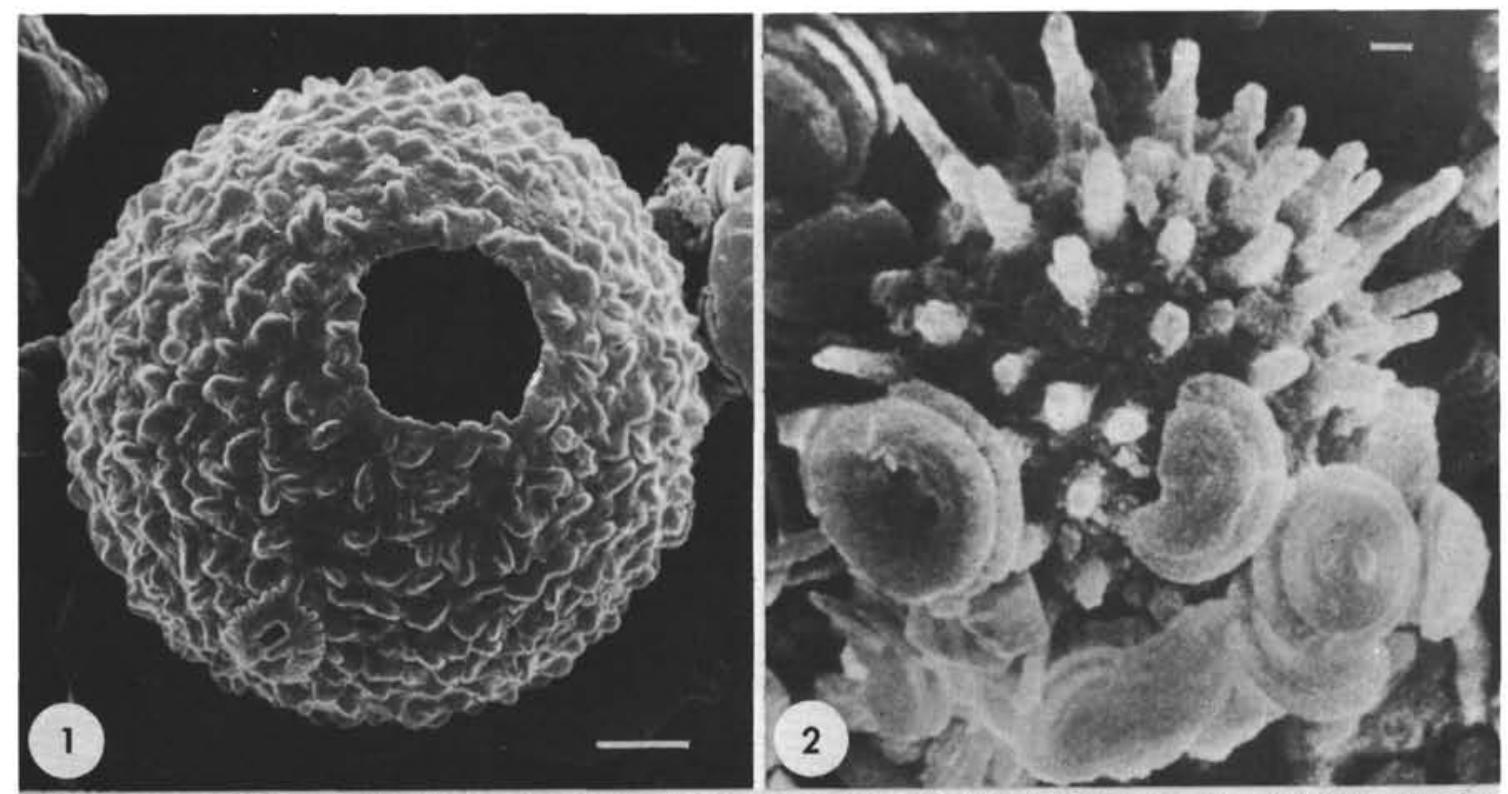

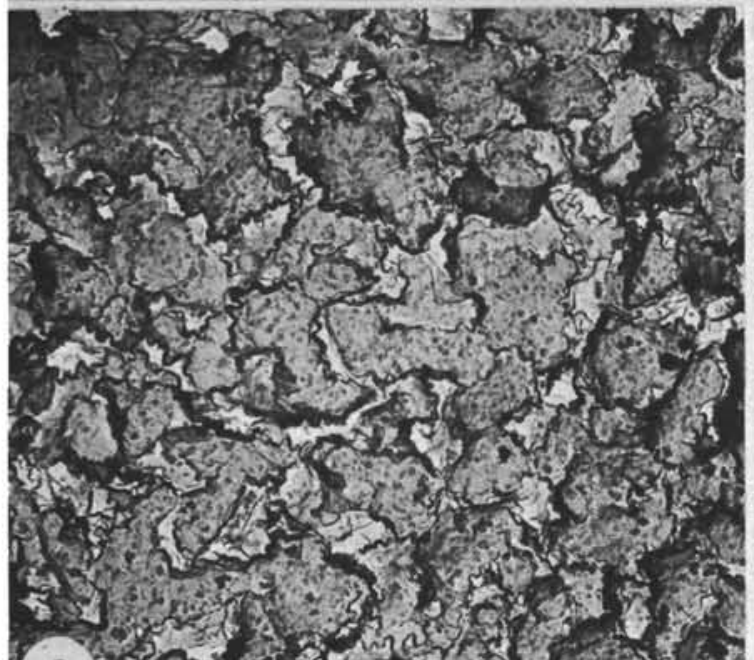
(3) 3 and

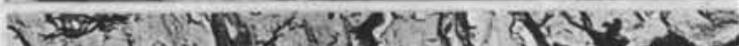

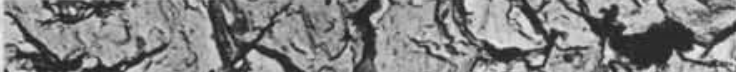

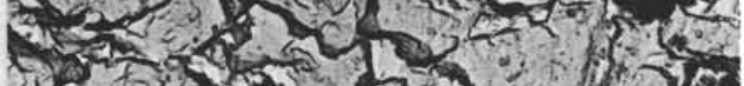
(1)

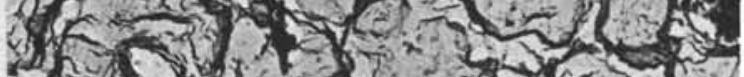

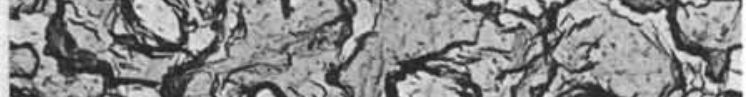

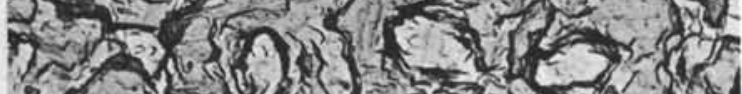
IS 1 . 513 कर 3 कर

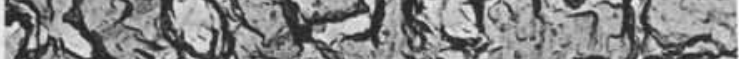

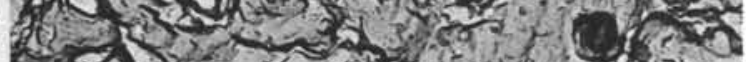

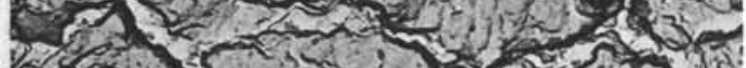
2. 5 (1)

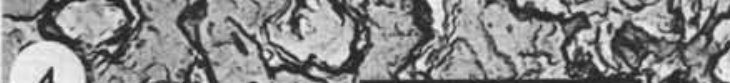

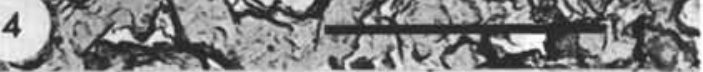

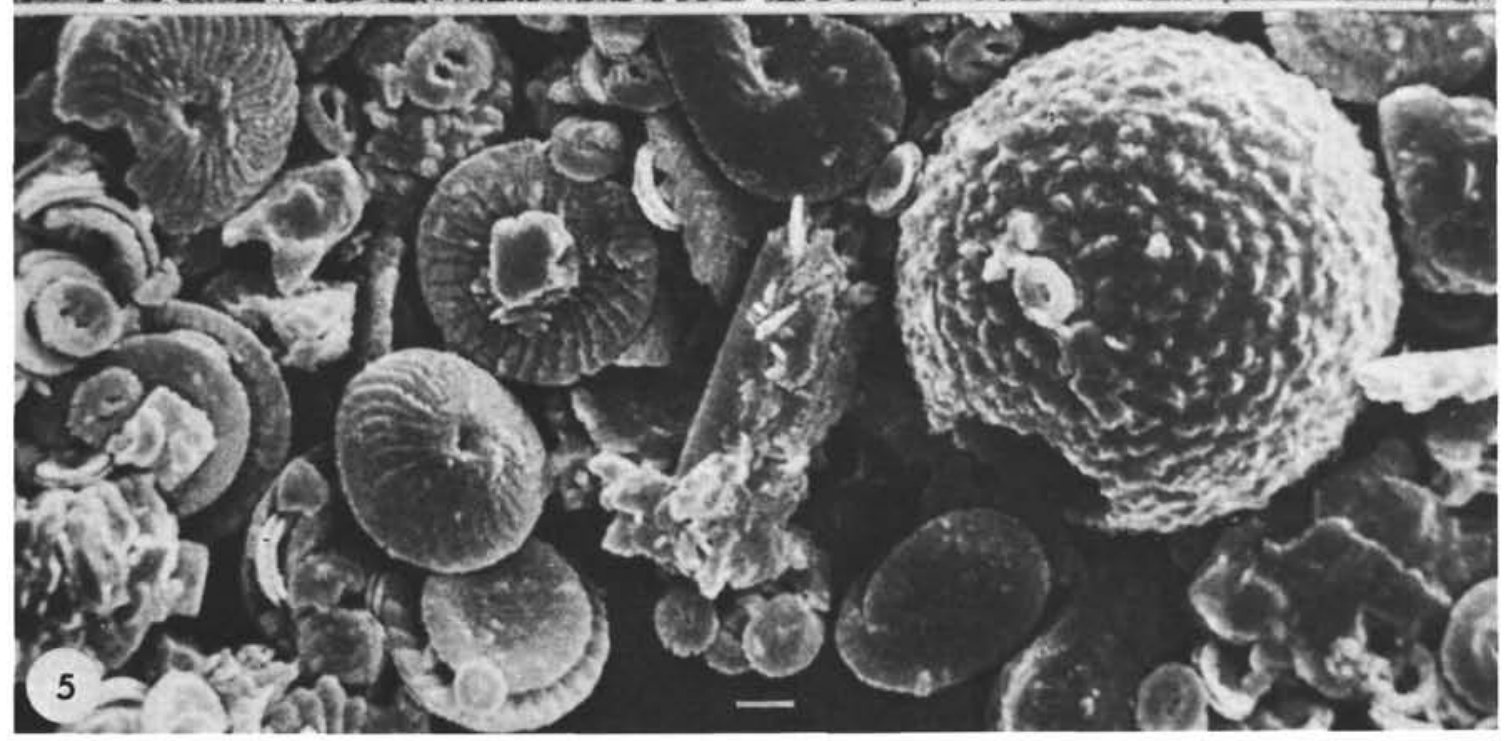


PLATE 31
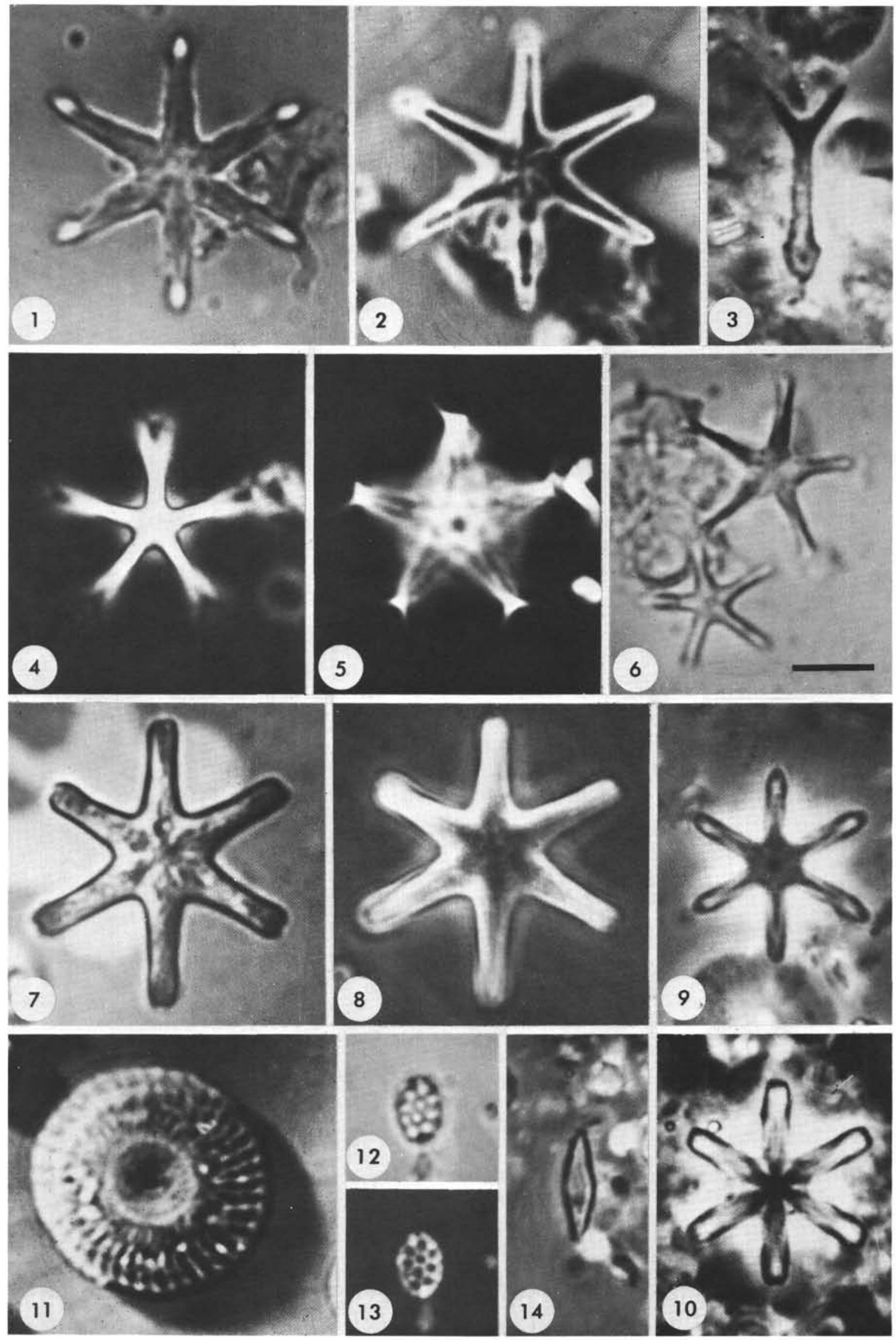


\section{PLATE 32}
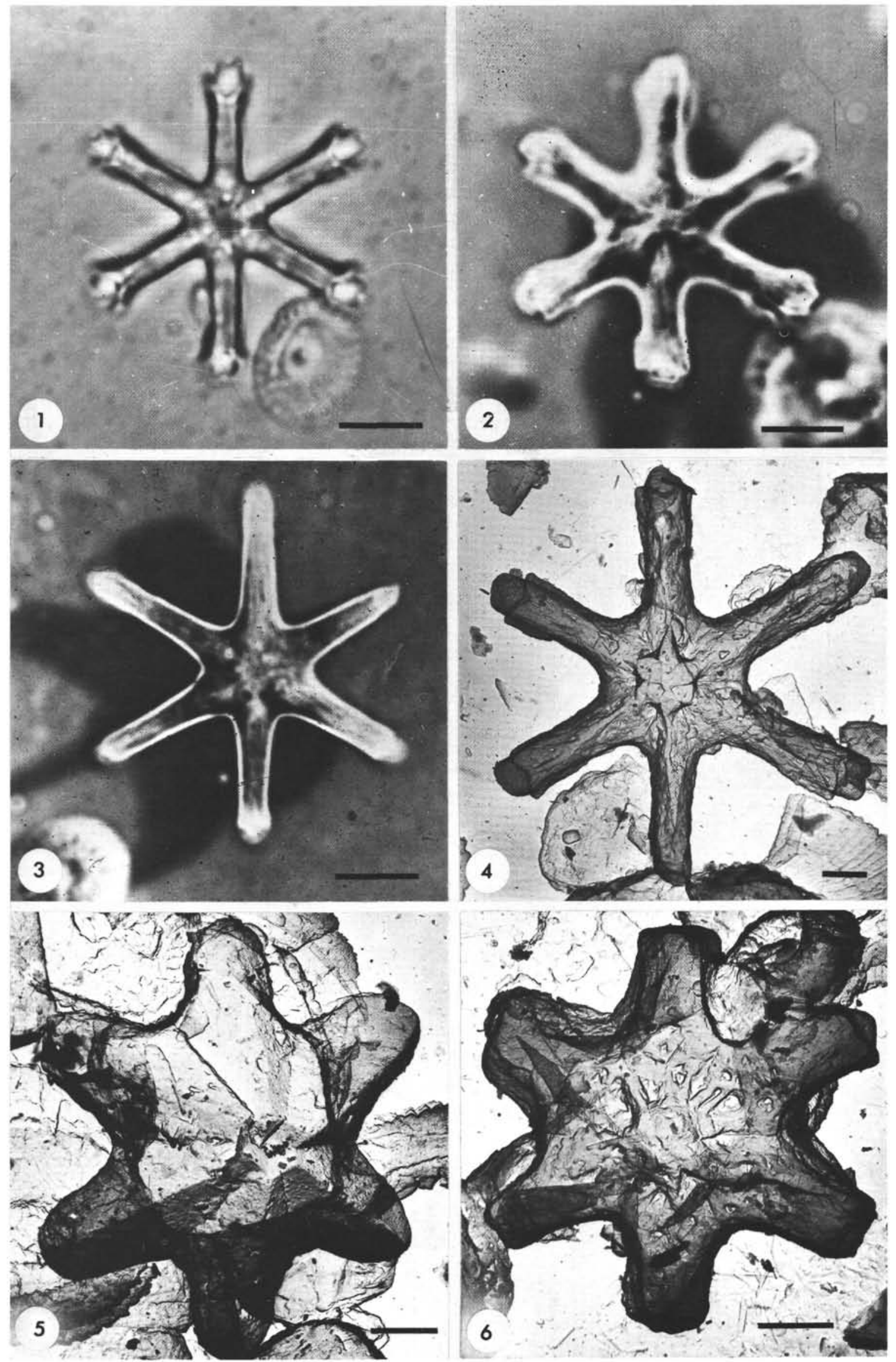
PLATE 33

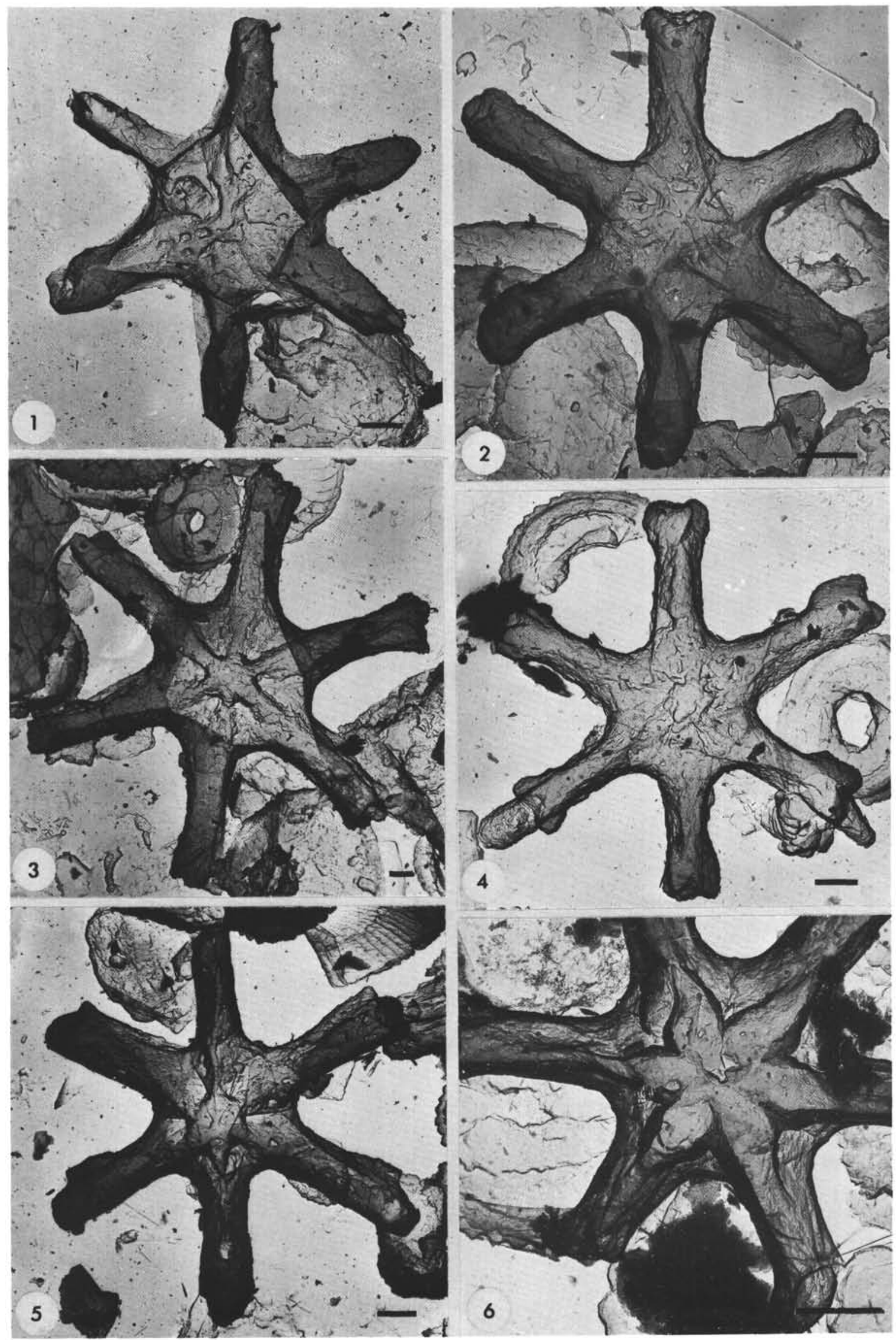


PLATE 34

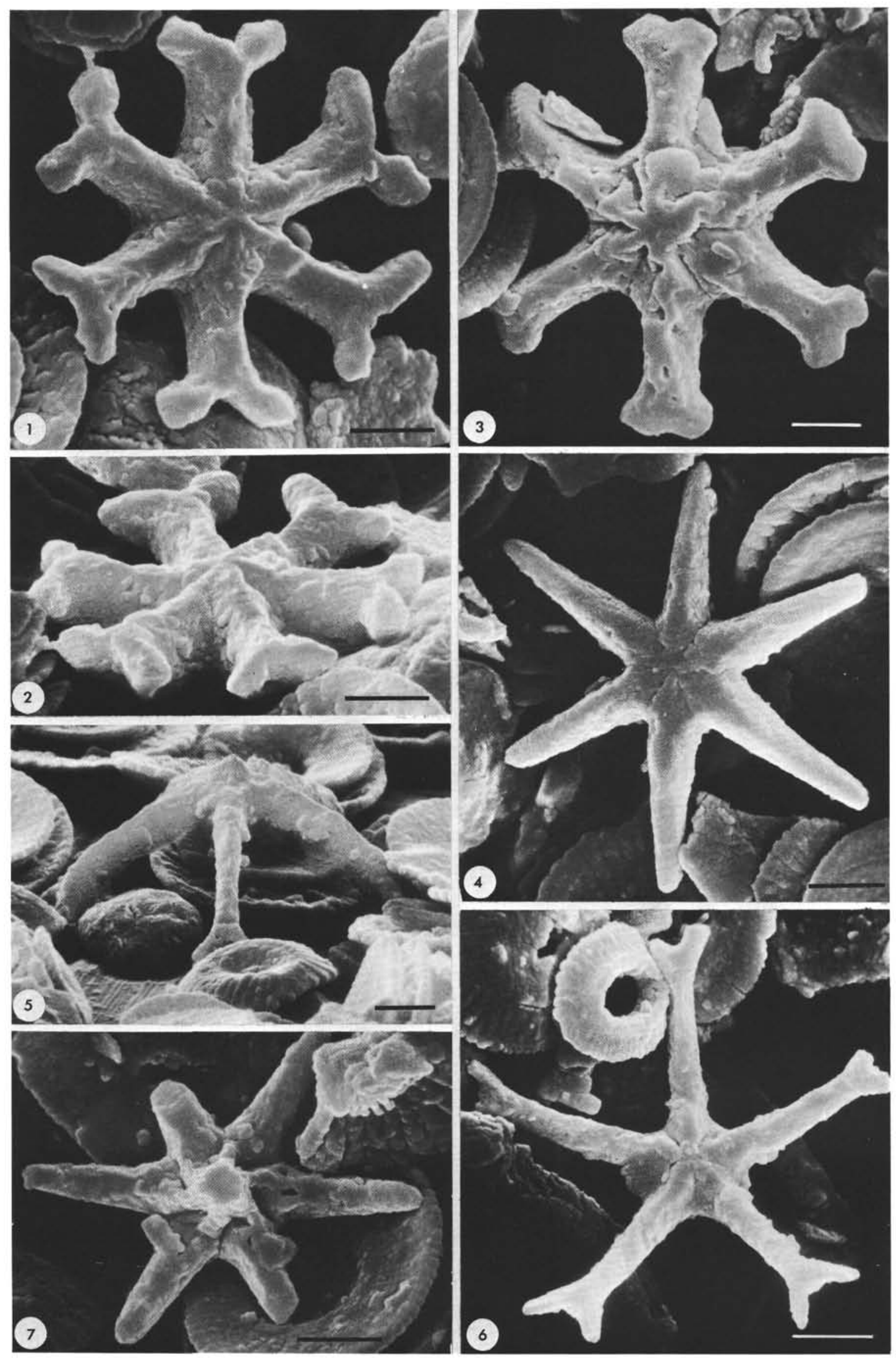


PLATE 35
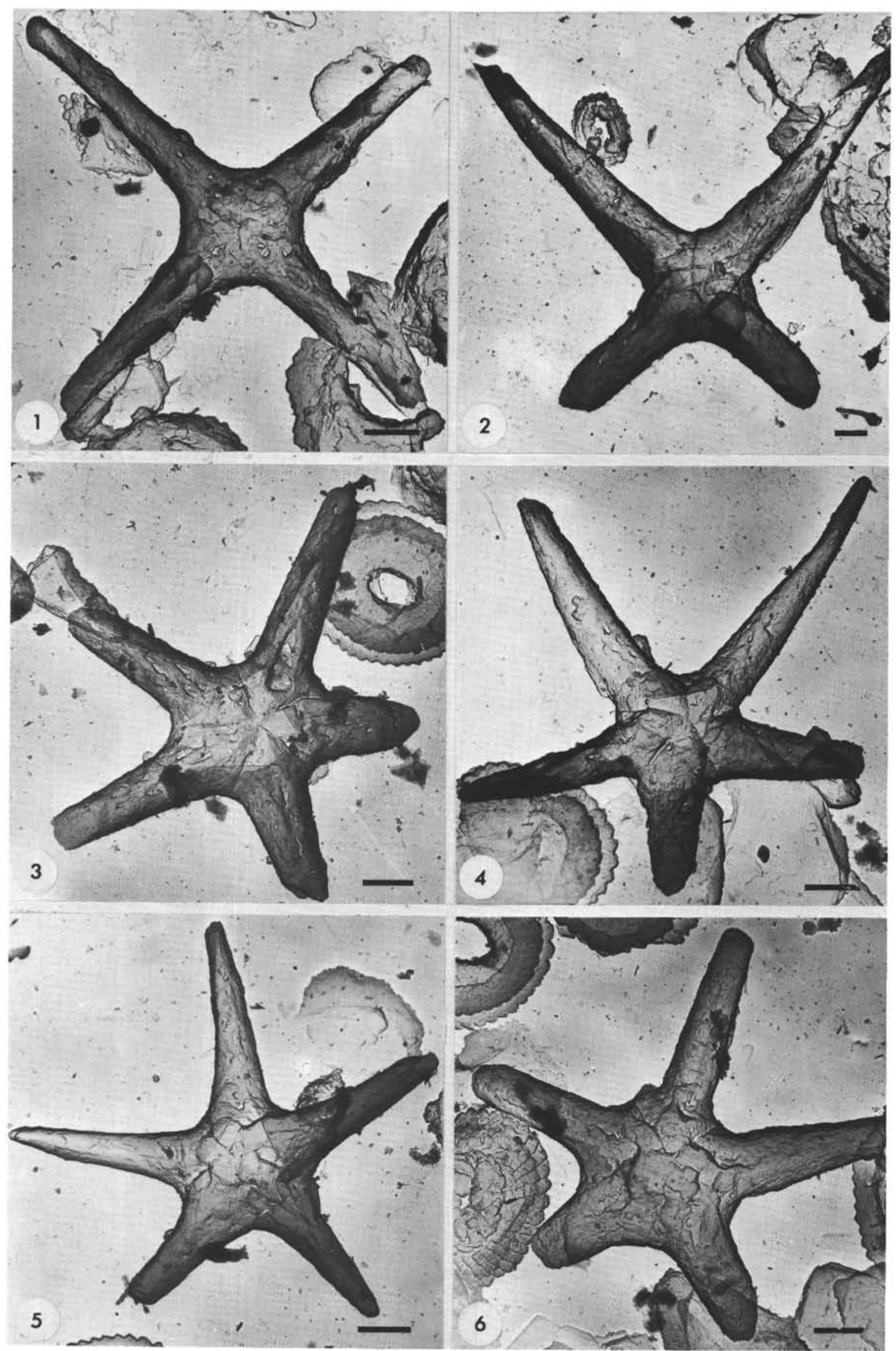
PLATE 36

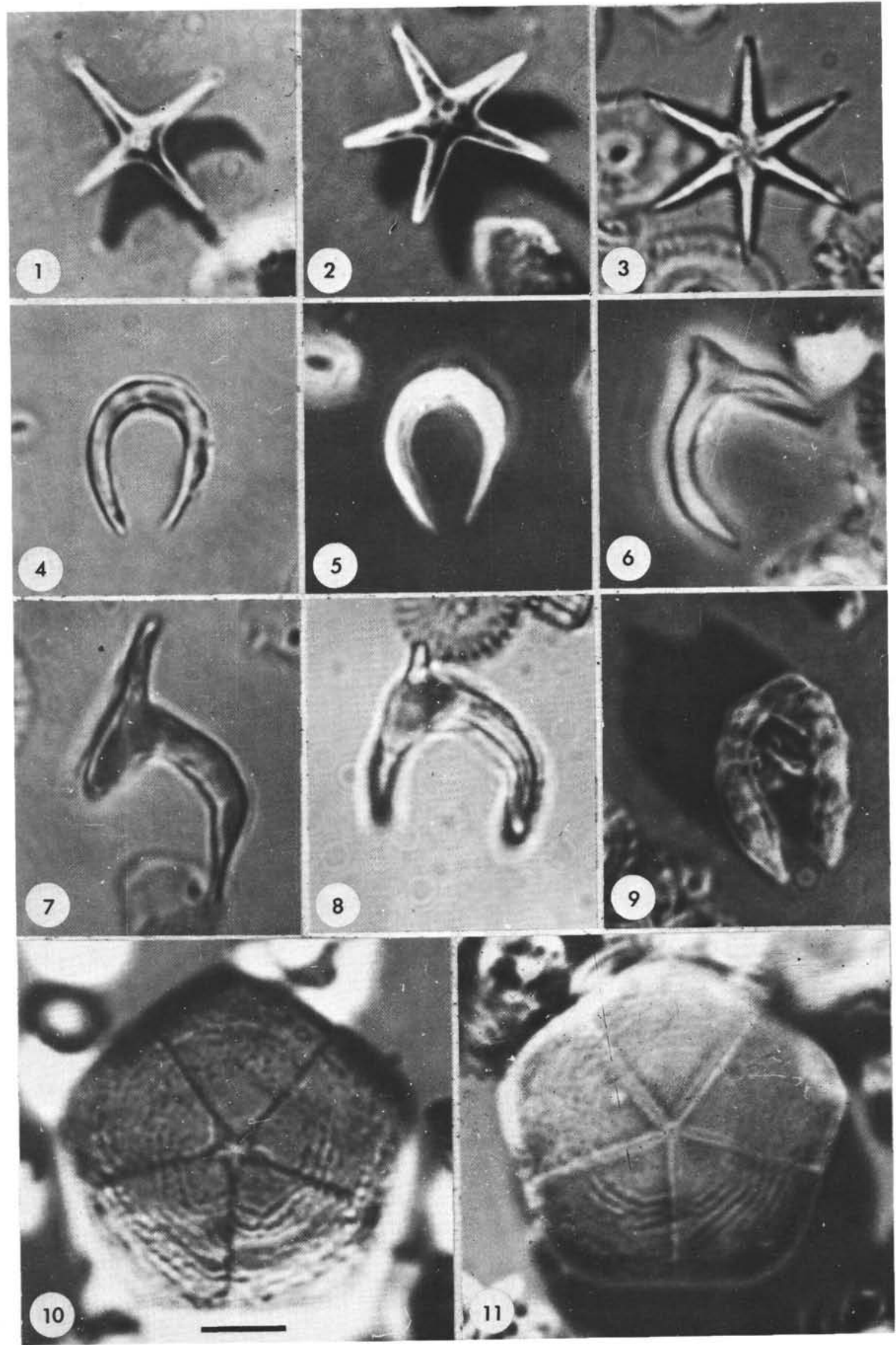


PLATE 37
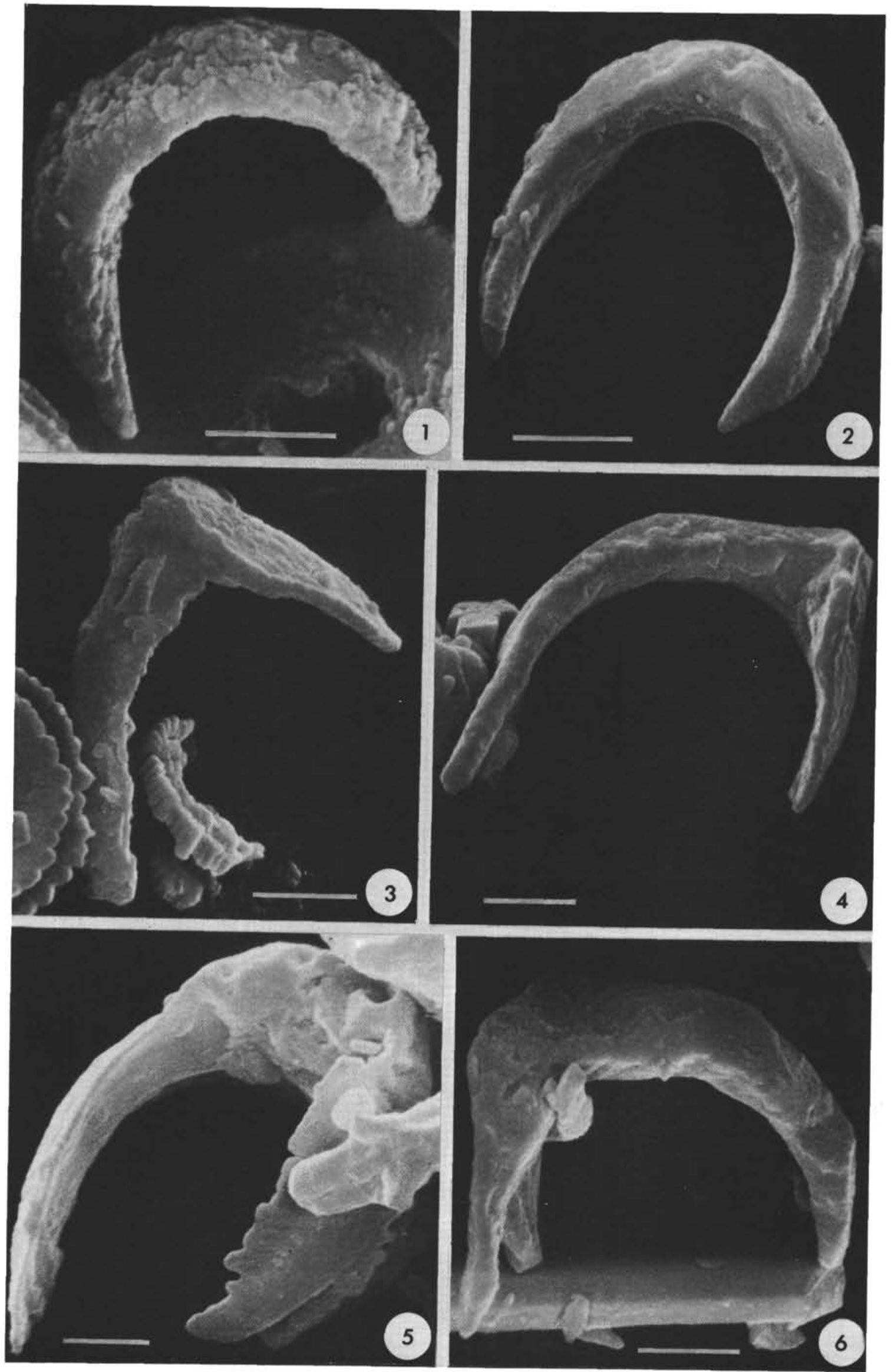


\section{PLATE 38}

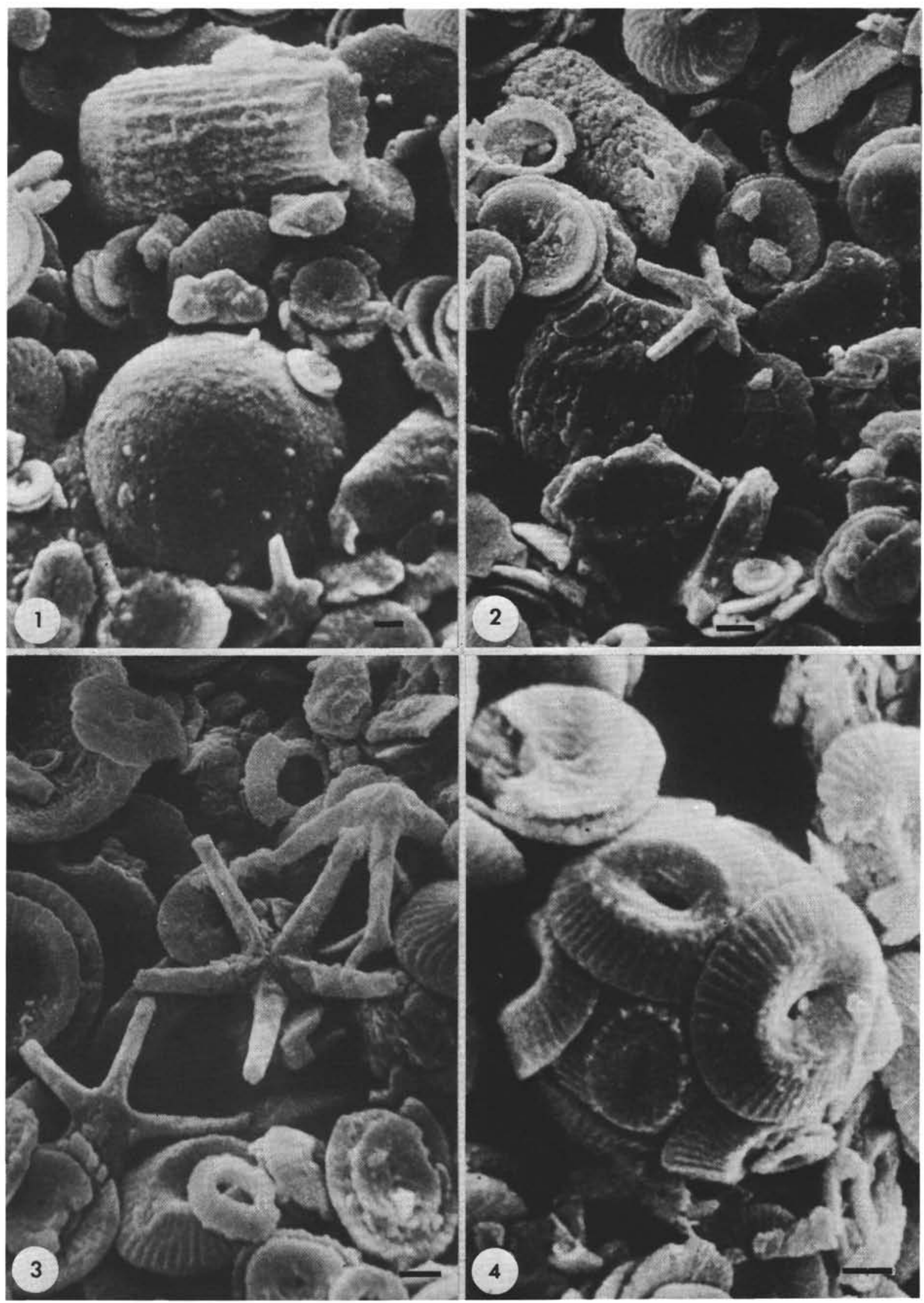




\section{PLATE 39}
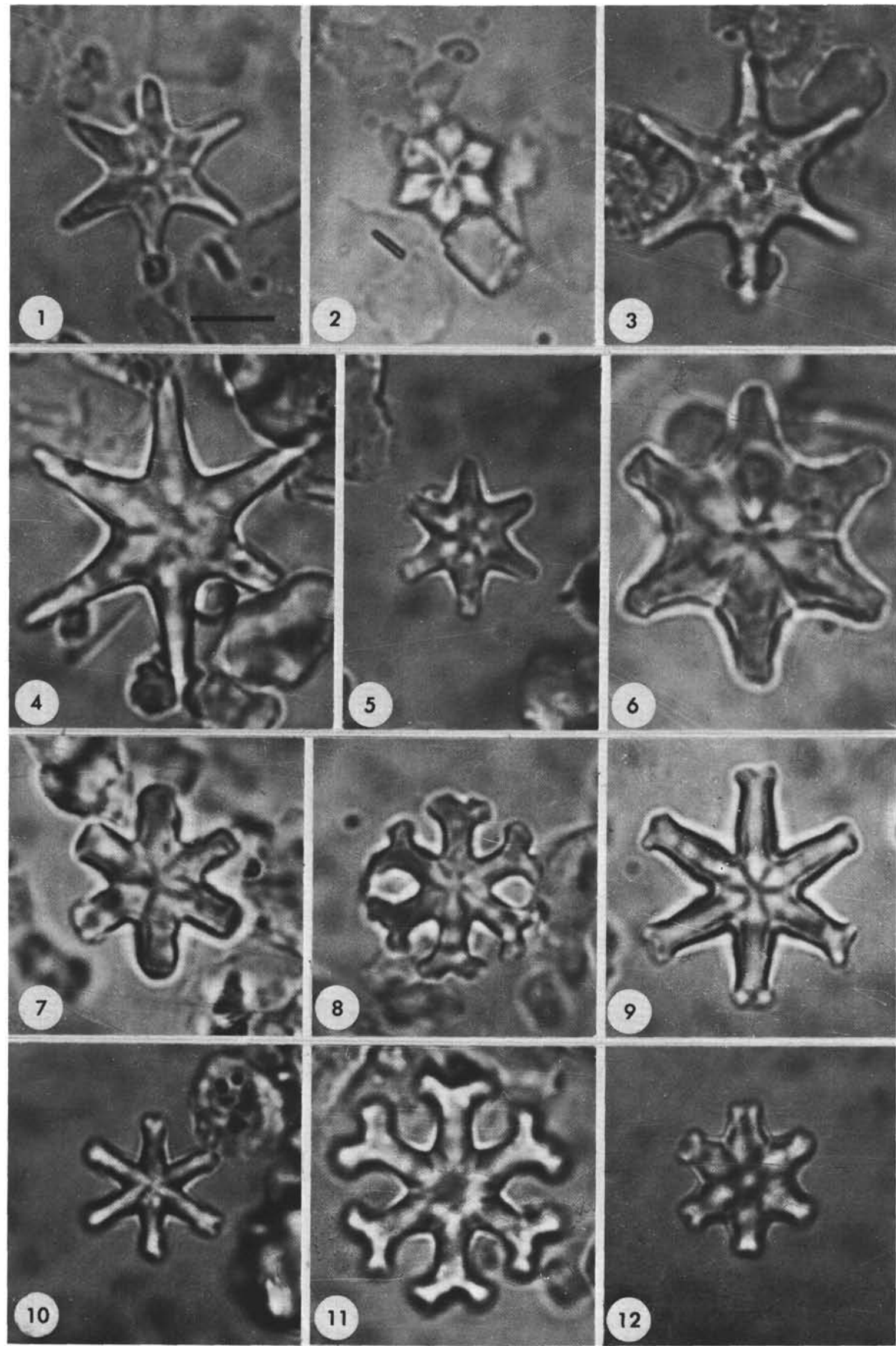
PLATE 40
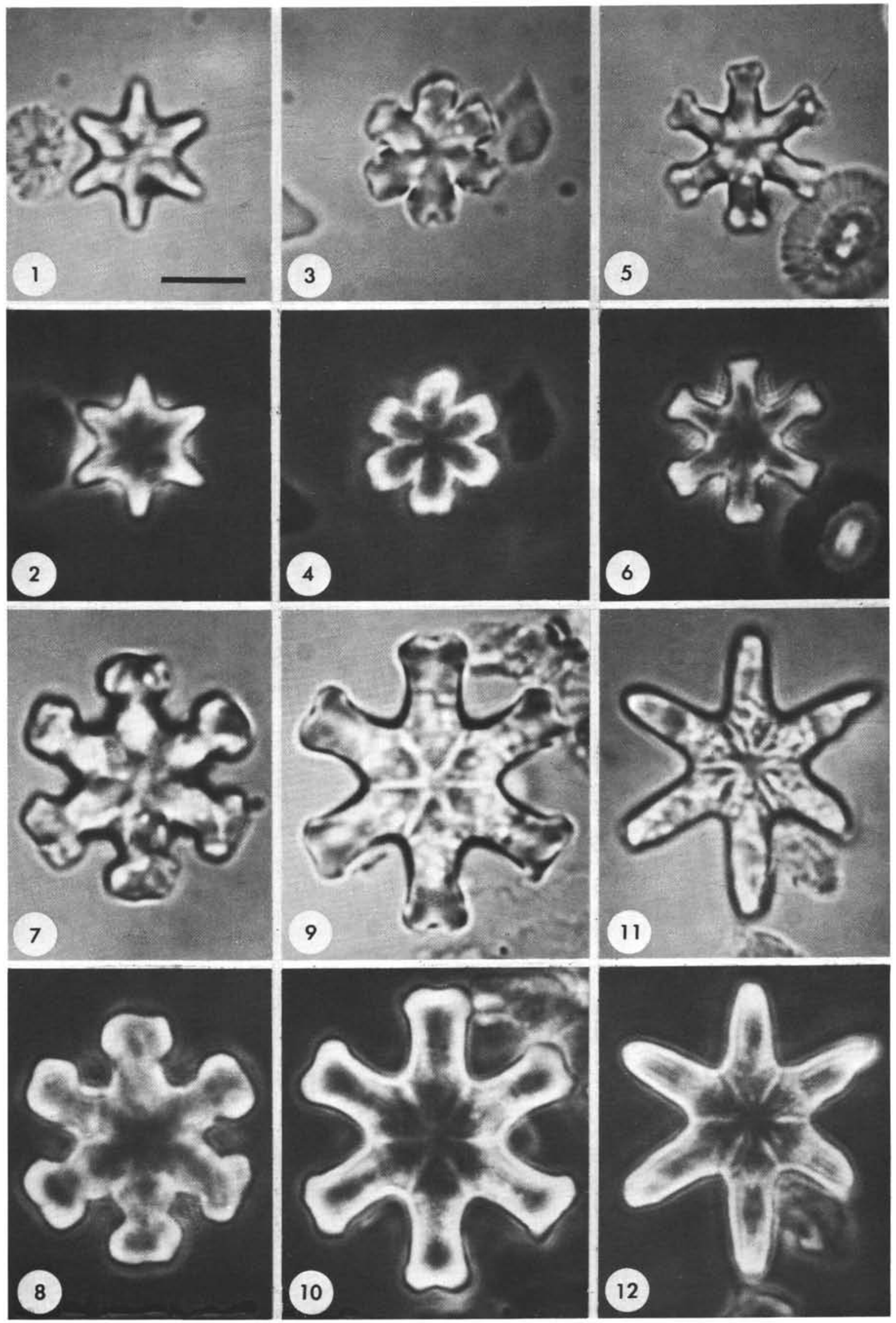
PLATE 41
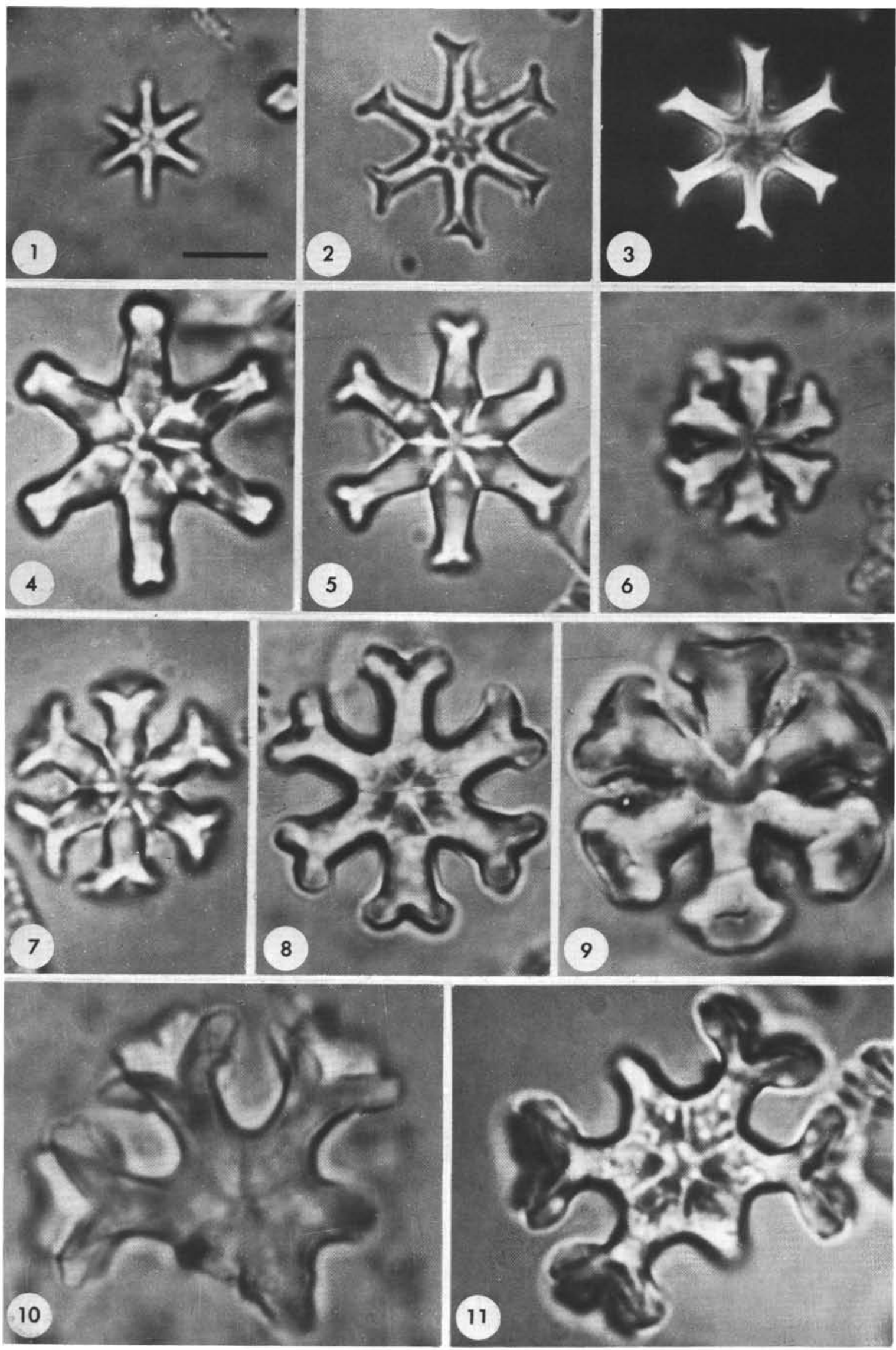
PLATE 42
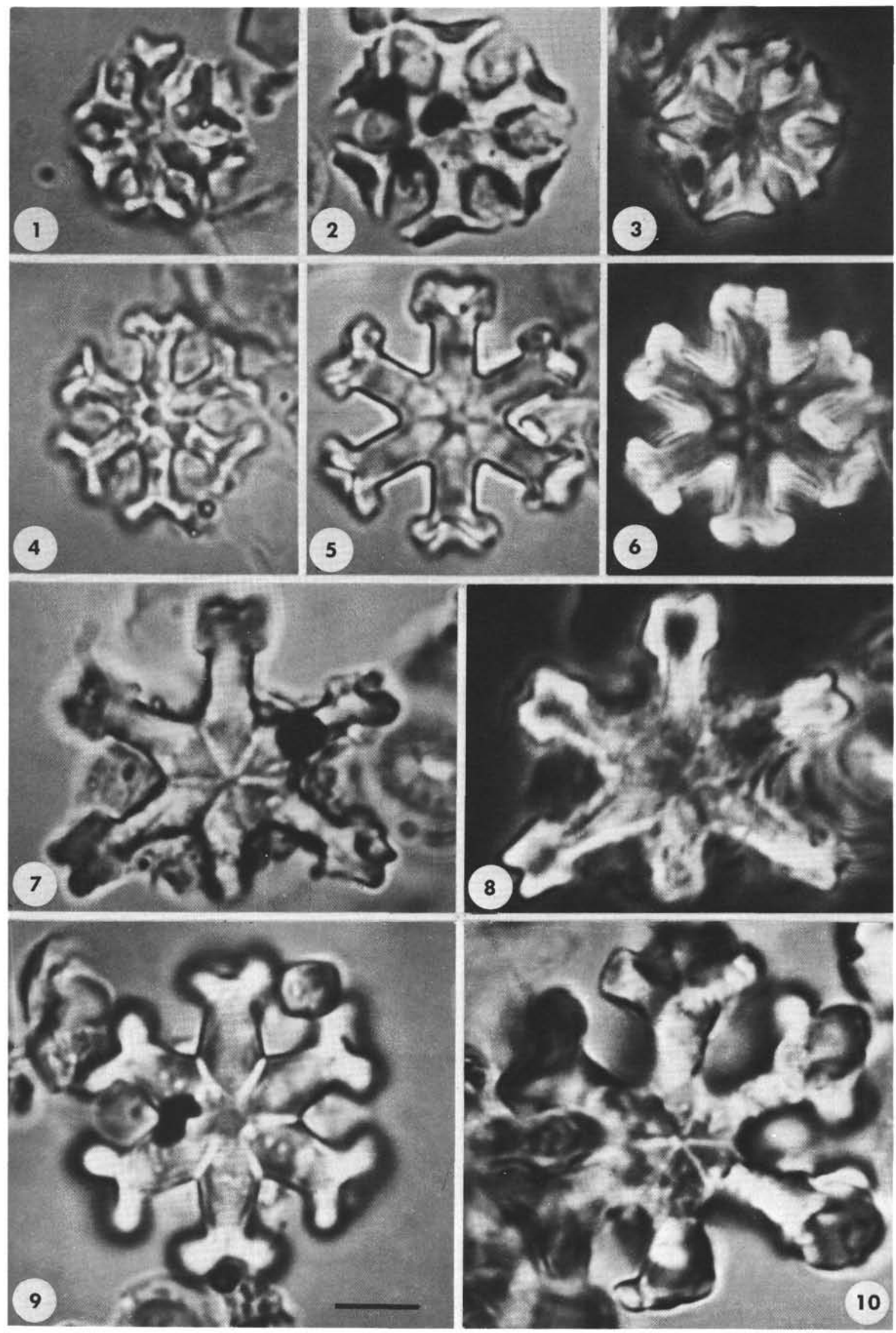


\section{PLATE 43}
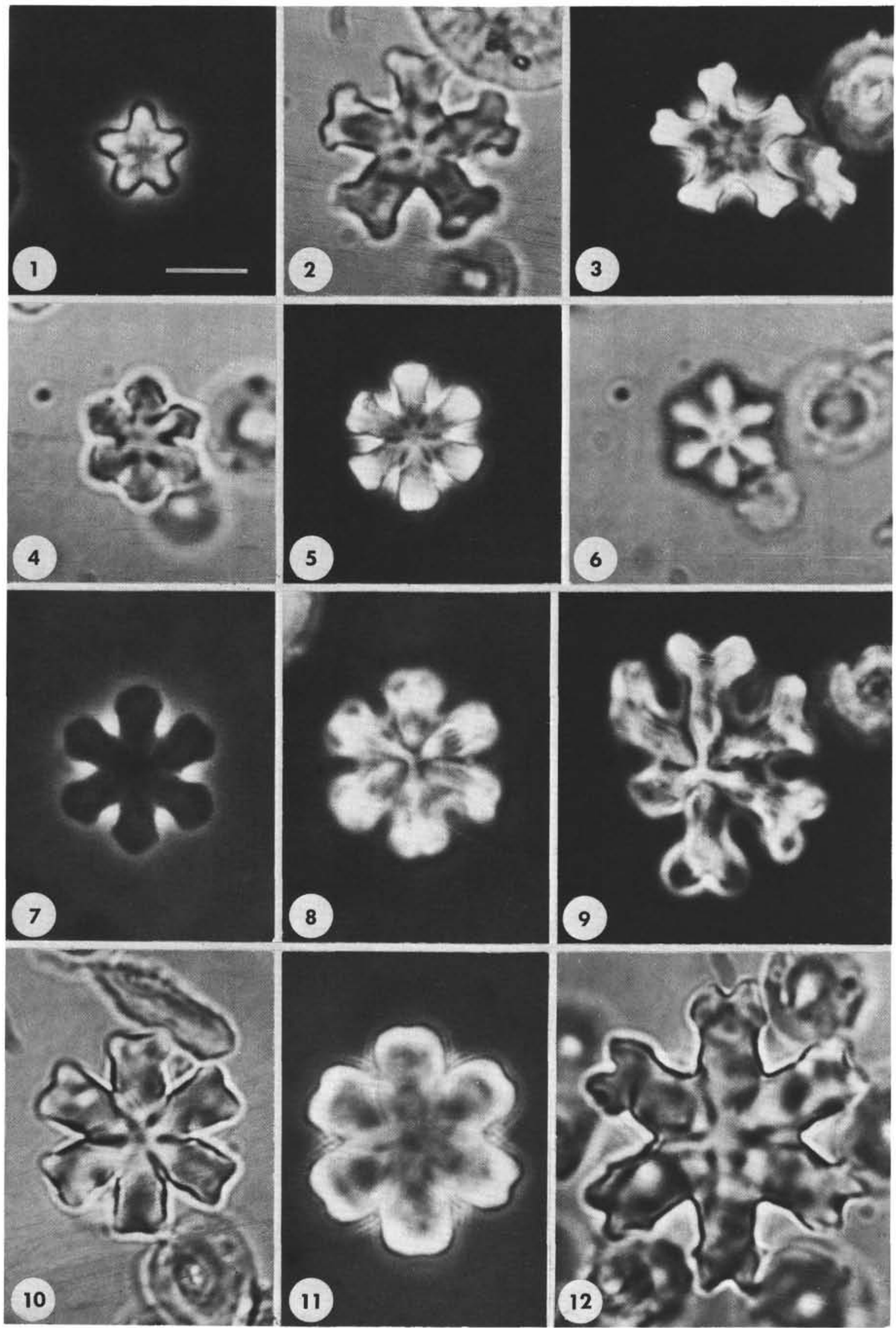
PLATE 44

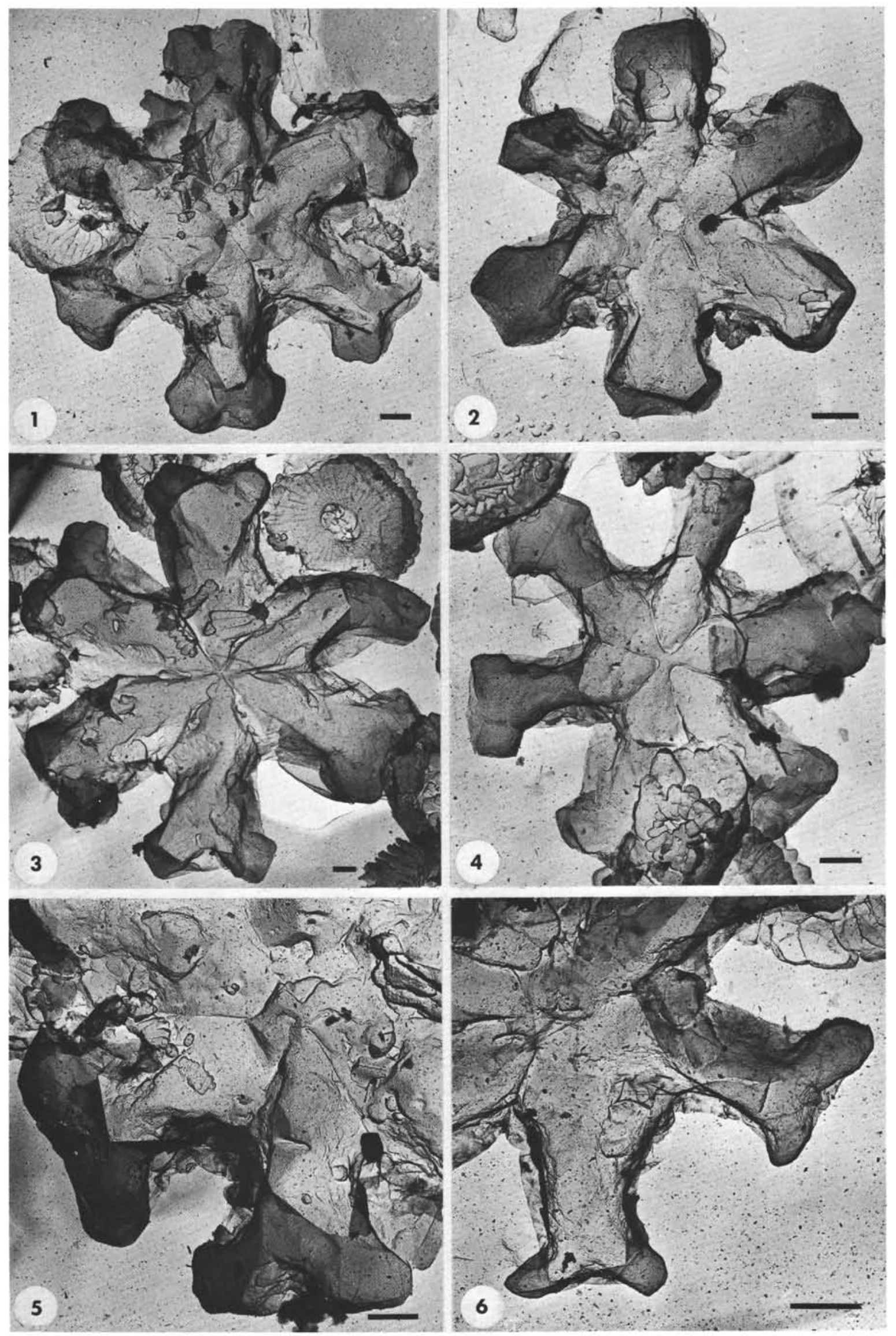


PLATE 45

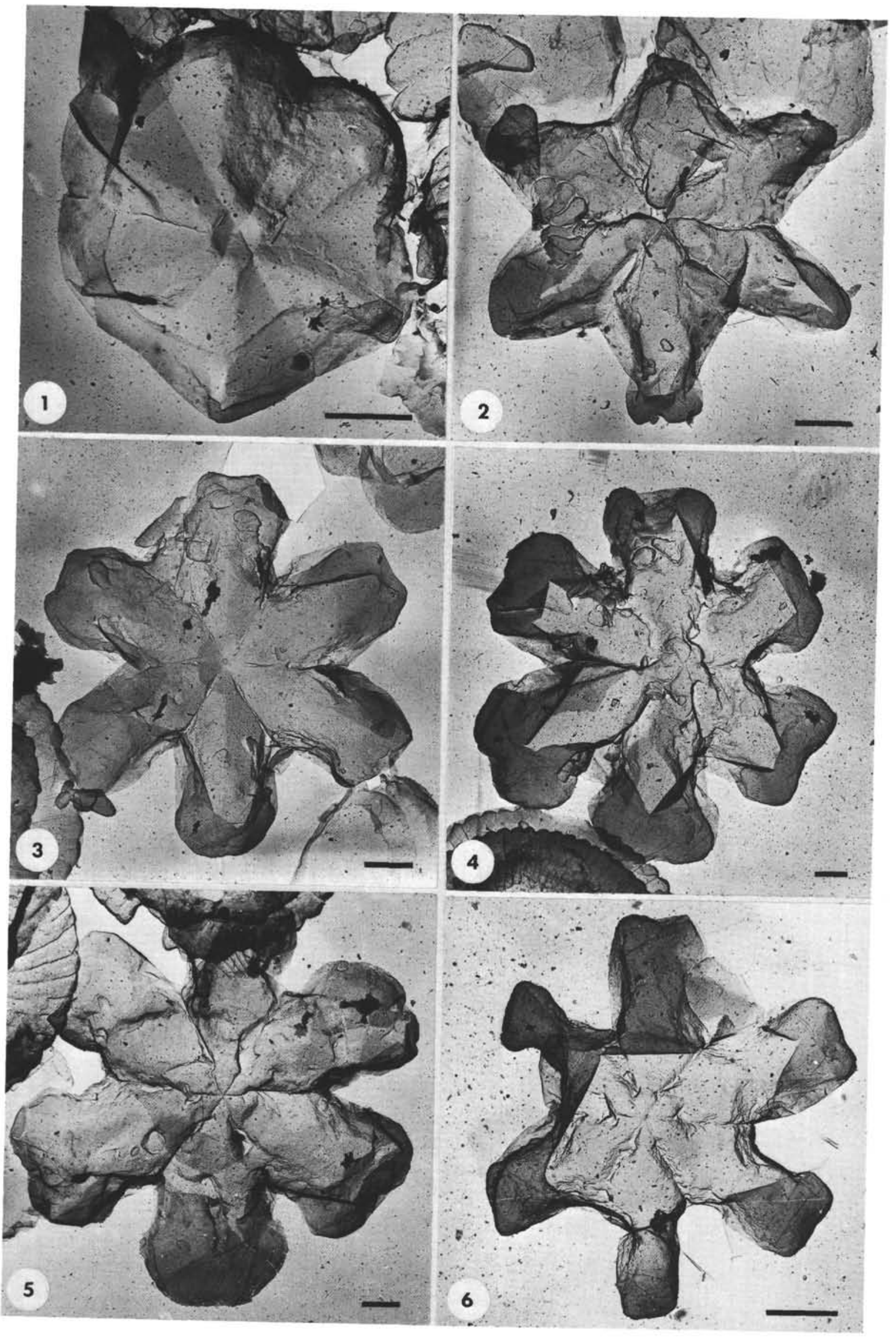



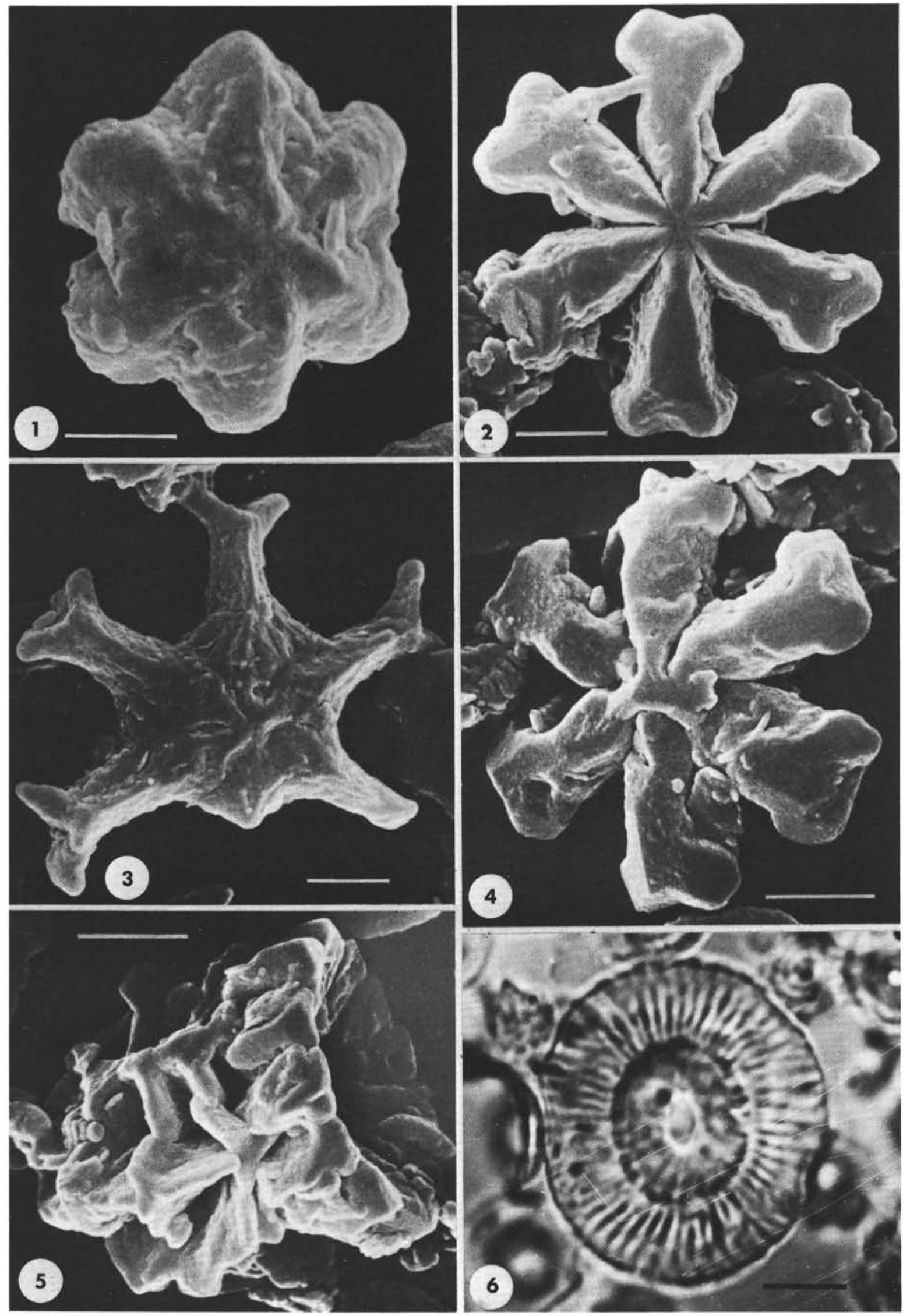
PLATE 47
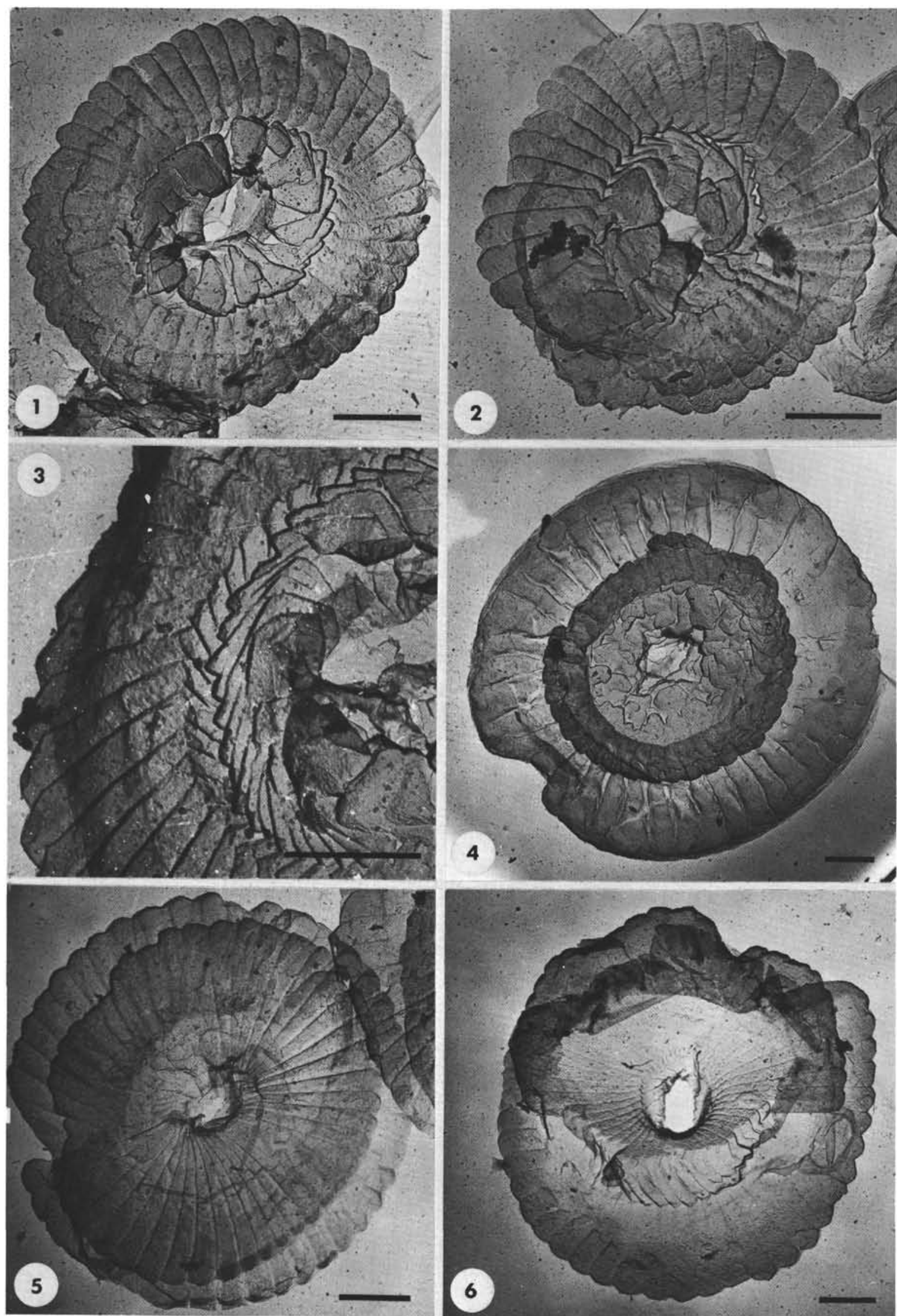
PLATE 48
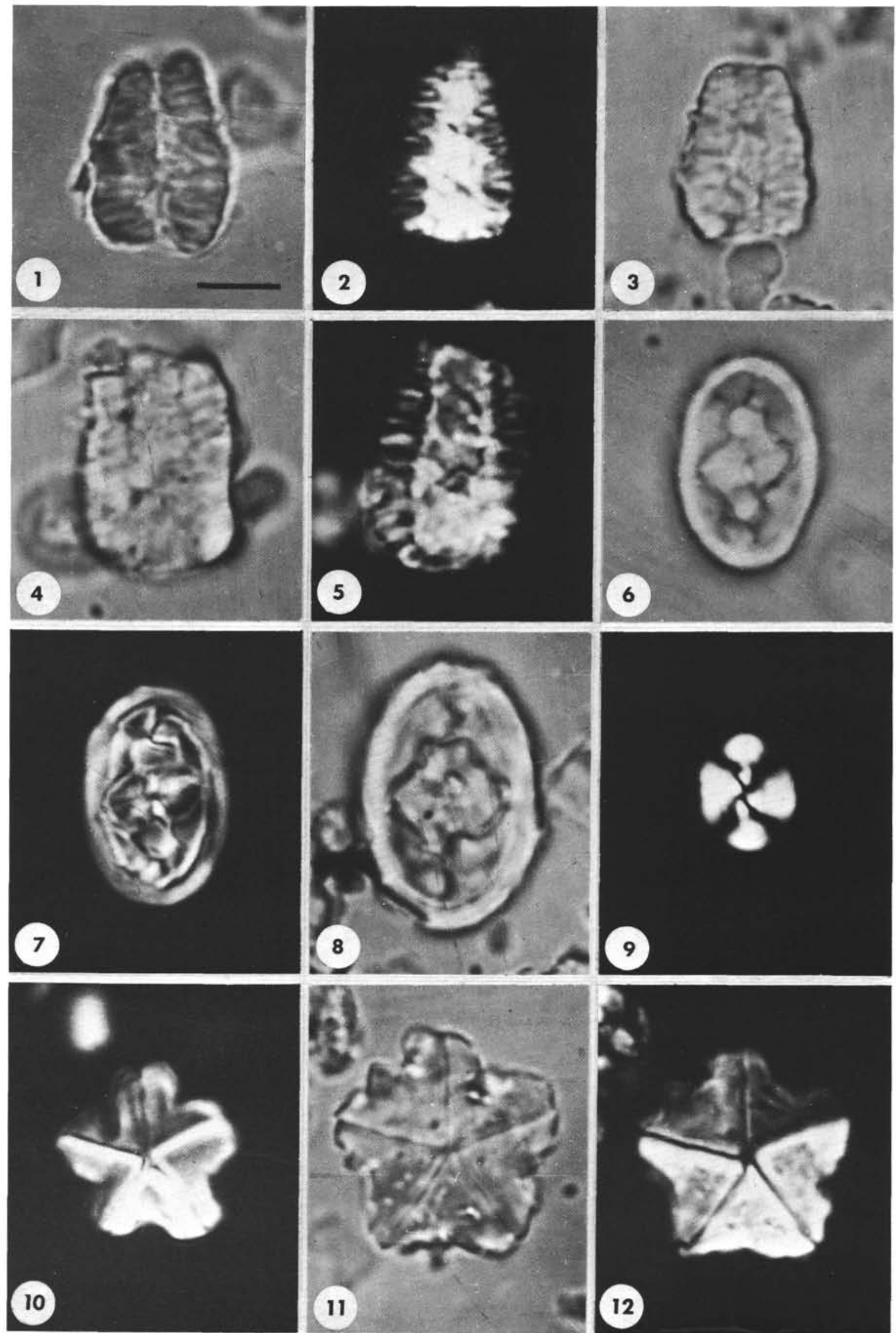
PLATE 49
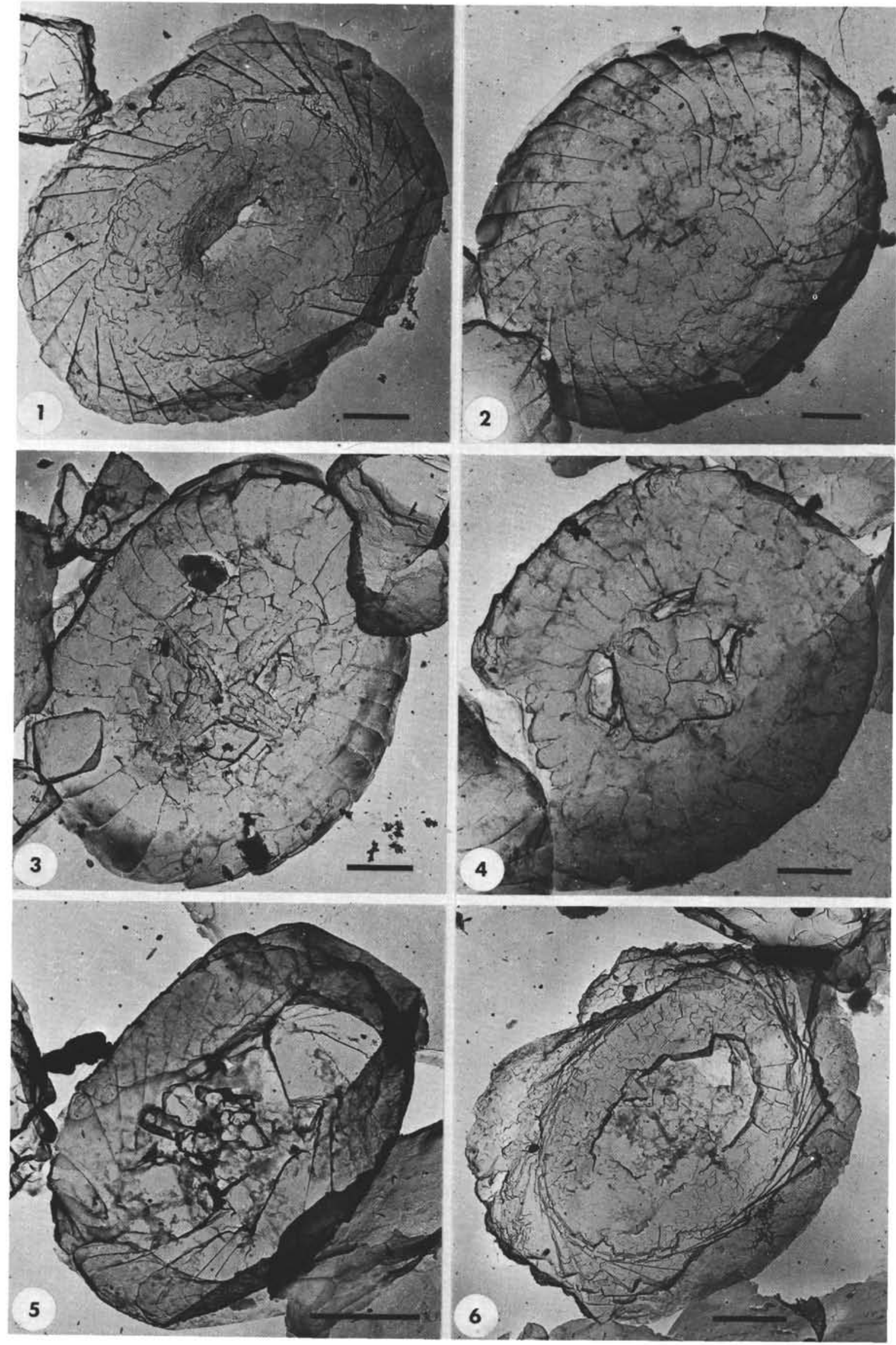
PLATE 50
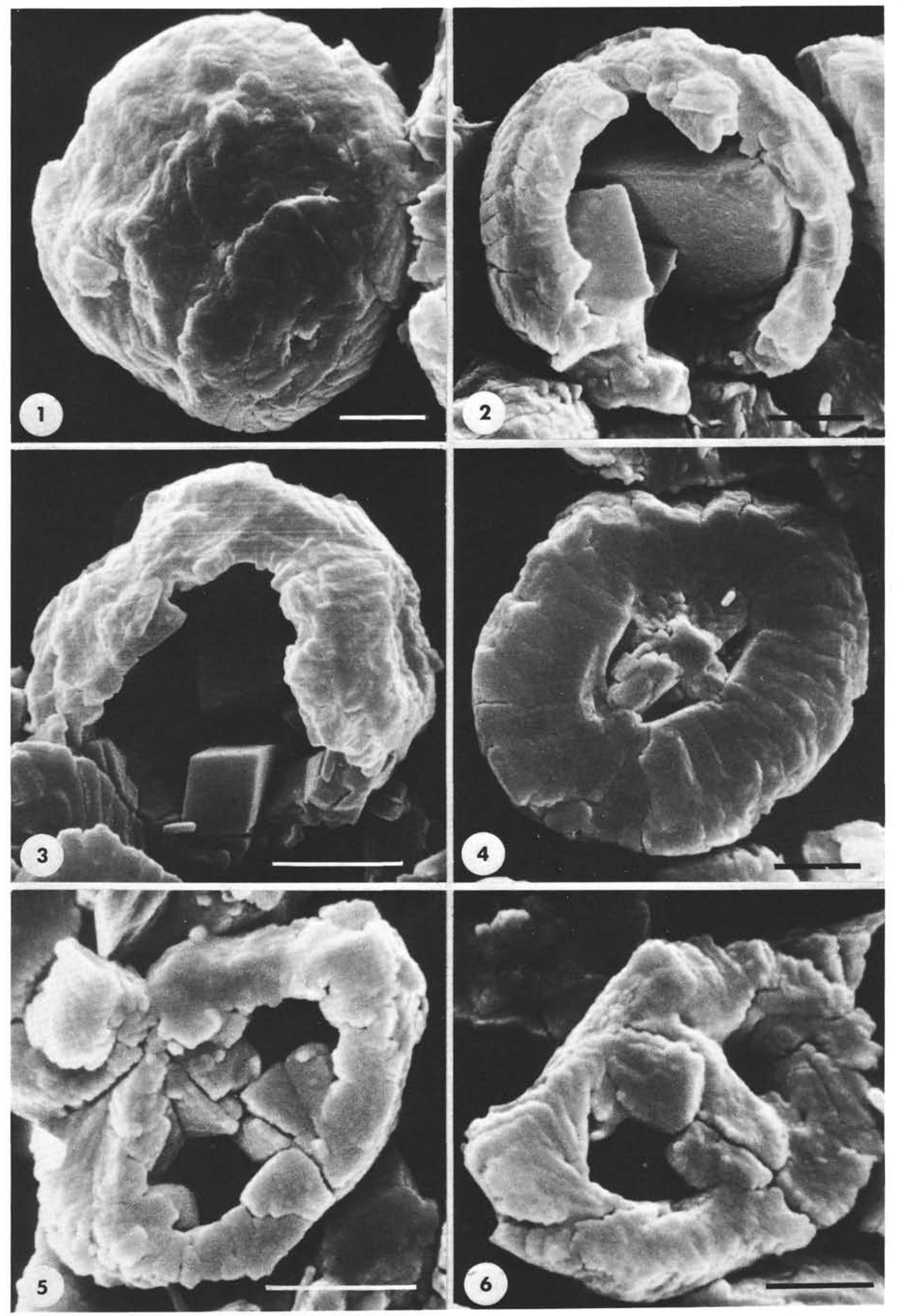


\section{PLATE 51}
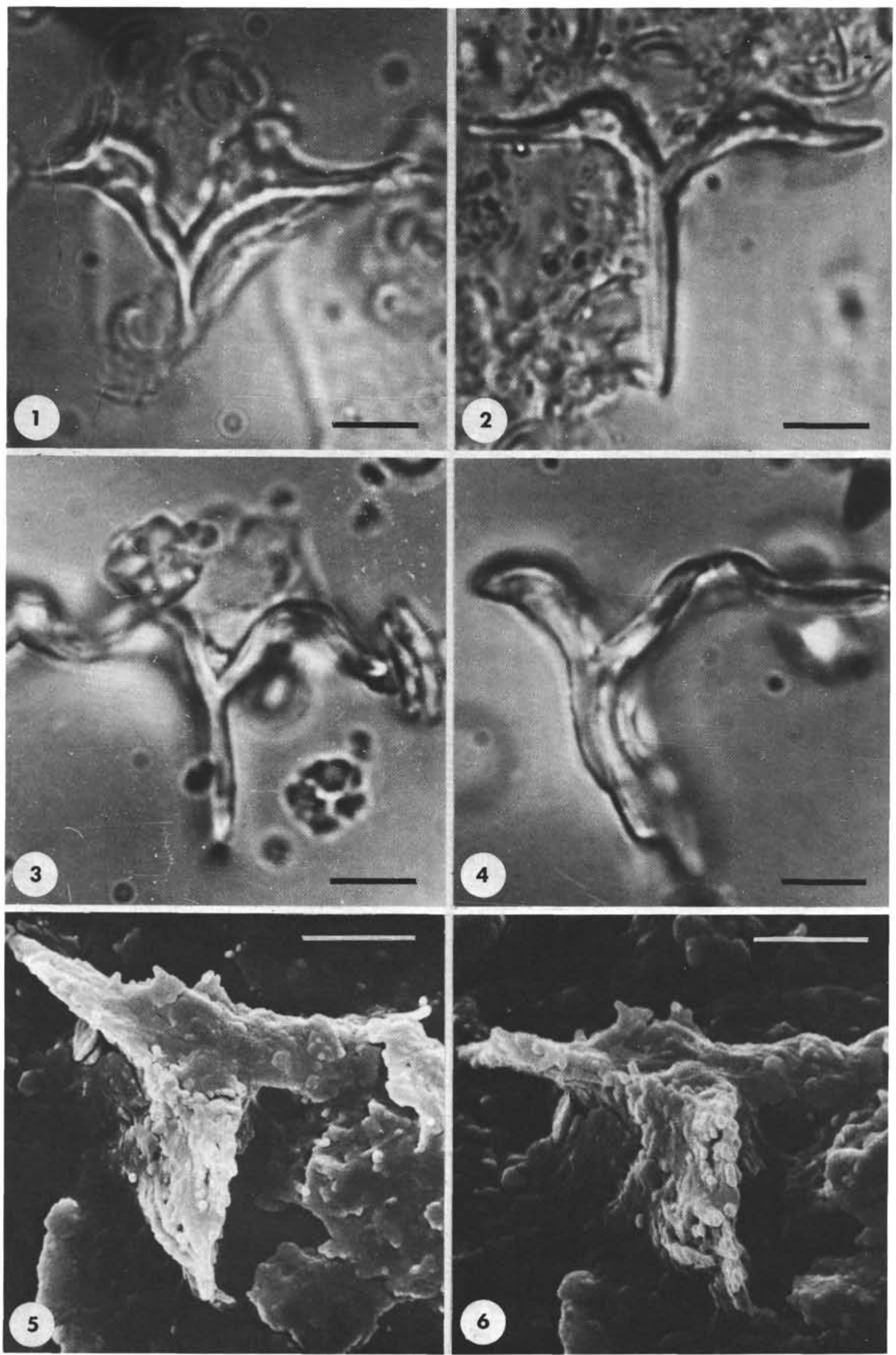


\section{PLATE CAPTIONS}

\section{PLATE 1}

Coccolithus pelagicus, (Wallich) Schiller, Scale bar: 1 micron

Figure 1. Distal view showing distal shield consisting of 48 crystal plates; central bridge narrow.

Figure 2. Distal view of coccolith with 46 crystal plates composing the distal shield; central bridge wide.

Figure 3. Proximal view showing the concave proximal shield surrounding the central area, which is set off by an elliptical suture.

Figure 4. Proximal view of coccolith with proximal plate partly broken off, thus permitting a glance at the insertion zone of the proximal shield.

Figure 5. Proximal view of coccolith with narrow bent bridge.

Figure 6. Oblique proximal view showing lamination of proximal shield and transverse bridge with furrow.

Sample: 13-132-12, CC. NN 15, Reticulofenestra pseudoumbilica Zone, Lower Pliocene.

\section{PLATE 2}

Scale bar: 1 micron.

Figure 1. Coccolithus pelagicus (Wallich) Schiller. Distal view.

Figure 2. Coccolithus pelagicus (Wallich) Schiller. In oblique distal view.

Figure 3. Coccolithus pelagicus (Wallich) Schiller. Proximal view. Sample: 13-132-1-5, $74 \mathrm{~cm}$. NN 21, Late Quaternary.

Figure 4. Coccolithus pelagicus (Wallich) Schiller. Distal view of smaller coccolith without central bridge.

Sample: 13-132-7-2, $90 \mathrm{~cm}$. NN 19, Pseudoemilia lacunosa Zone, Early Quaternary.

Figure 5. Coccolithus pelagicus (Wallich) Schiller. Distal view of coccolith without central bridge. The wall-elements are not overlapping the inner margin of the distal shield.

Sample: 13-134-7-2, Top. NN 12, Ceratolithus tricorniculatus Zone.

Figure 6. Coccosphere of Coccolithus pelagicus (Wallich) Schiller. Some coccoliths are with, some without central bridge.

Sample: 13-132-18-3, $15 \mathrm{~cm}$. NN 12, Ceratolithus tricorniculatus Zone, Lower Pliocene.

\section{PLATE 3}

Scale bar: 1 micron.

Figure 1. Reticulofenestra pseudoumbilica (Gartner). Distal view of coccolith with open central area, wall with cover plates.

Figure 2. Reticulofenestra pseudoumbilica (Gartner). Proximal view of coccolith, central area filled with a grid consisting of elongate laths.

Figure 3. Reticulofenestra pseudoumbilica (Gartner). Distal view of a coccosphere showing how the coccoliths are assembled and how they overlap.

Figure 4. Reticulofenestra pseudoumbilica (Gartner). Complete coccosphere: the central area of the coccoliths is closed with cover plates; one coccolith with an extraordinary aperture.

Figure 5. Gephyrocapsa cf. aperta Kamptner. Distal view of single coccoliths with bipartite oblique bridges.

Sample: 13-132-12, CC. NN 15, Reticulofenestra pseudoumbilica Zone, Lower Pliocene.

\section{PLATE 4}

Scale bar: 1 micron.

Figure 1. General view of an assemblage, which for its greater part consists of isolated coccoliths of Gephyrocapsa oceanica (small forms) and Cyclococcolithus leptoporus (large forms).

Sample: $13-132-4-4,100 \mathrm{~cm}$. NN 20, Gephyrocapsa oceanica Zone, Middle Quaternary.
Figure 2. Complete coccosphere of Gephyrocapsa oceanica Kamptner. The transversal bridges are highly vaulted.

Sample: 13-132-7-2, $90 \mathrm{~cm}$. NN 19, Pseudoemilia lacunosa Zone, Lower Quaternary.

Figure 3. Gephyrocapsa oceanica Kamptner. Distal view.

Figure 4. Gephyrocapsa oceanica Kamptner. Oblique distal view.

Figure 5. Gephyrocapsa oceanica Kamptner. Proximal view.

Sample: 13-130-3-1, $1 \mathrm{~cm}$. NN 19, Pseudoemilia lacunosa Zone, Lower Quaternary.

Figure 6. Gephyrocapsa oceanica Kamptner. Distal view of very small coccolith showing a crystal cycle between the inner wall and the distal shield.

Sample: 13-132-1-5, $74 \mathrm{~cm}$. Late Quaternary.

\section{PLATE 5}

Pseudoemilia lacunosa Kamptner. Scale bar: 1 micron.

Figure 1. Distal view of coccolith with open slots in the distal shield.

Figure 2. Distal view of coccolith with closed slots.

Figure 3. Distal view of coccolith with sparsely spaced slots.

Figure 4. Proximal view of coccolith.

Figure 5,6. Unidentified coccoliths showing signs of beginning solution.

Sample: 13-132-12, CC. NN 15, Reticulofenestra pseudoumbilica Zone, Lower Pliocene.

\section{PLATE 6}

Scale bar: 1 micron.

Figure 1. Coccosphere of Coccolithus sp.

Figures 2,3. Coccosphere of Coccolithus doronicoides Black and Barnes; the close-up (Figure 2) shows that some coccoliths have an internal grid, which is missing in others.

Sample: 13-125-4, CC. NN 18, Discoaster brouweri Zone, Upper Pliocene.

Figure 4. Coccosphere of Reticulofenestra pseudoumbilica Gartner. To be recognized by the cover plates forming a wall around the central apertures of the coccoliths.

Figure 5. Coccosphere of Reticulofenestra cf. pseudoumbilica Gartner. Some coccoliths still show traces of central membrane. Diameter of coccosphere only half of that shown in Figure 4.

Sample: 13-132-18-3, $25 \mathrm{~cm}$. NN 12, Ceratolithus tricorniculatus Zone, Lower Pliocene.

Figure 6. Pseudoemilia lacunosa Kamptner. Complete coccosphere. Sample: 13-125-4, CC. NN 18, Discoaster brouweri Zone, Upper Pliocene.

\section{PLATE 7}

Scale bar: 1 micron.

Figure 1. Cyclococcolithus leptoporus (Murray and Blackman). Proximal view of well-preserved coccolith with sutures of the proximal shield partly straight, partly meandering. 24 sutures.

Figure 2. Cyclococcolithus leptoporus (Murray and Blackman). Details of meandering sutures.

Figure 3. Cyclococcolithus leptoporus (Murray and Blackman). Proximal side of an isolated distal shield. 23 sutures.

Figure 4. Cyclococcolithus leptoporus (Murray and Blackman). Central portion of some distal shield showing zone of insertion of the proximal shield.

Figure 5. Cyclococcolithus leptoporus (Murray and Blackman). Distal view of poorly preserved specimen, comparable with that of Plate 18, Figure 1. Due to corrosion of the elements, the 17 sutures are not so easily recognized. 
Figure 6. Oolithothus antillarum (Cohen). Proximal view showing the excentric position of the proximal shield with its claw-shaped elements. 18 sutures.

Sample: 13-130A-1, CC. NN 21, Late Quaternary.

\section{PLATE 8}

Scale bar: 1 micron.

Figure 1. Cyclococcolithus leptoporus (Murray and Blackman). Distal view of coccolith with 21 elements in distal shield.

Figure 2. Cyclococcolithus leptoporus (Murray and Blackman). Oblique distal view.

Sample: 13-132-7-2, $90 \mathrm{~cm}$. NN 19, Pseudoemilia lacunosa Zone, Lower Quaternary.

Figure 3. Cyclococcolithus macintyrei Bukry. Proximal view of distal shield consisting of 32 crystal elements. Proximal shield missing.

Sample: 13-132-18-3, $25 \mathrm{~cm}$. NN 12, Ceratolithus tricorniculatus Zone, Lower Pliocene.

Figure 4. Cyclococcolithus leptoporus (Murray and Blackman). Proximal view of over-calcified specimen; proximal shield with zigzag sutures.

Sample: 13-130-3-1, $1 \mathrm{~cm}$. NN 19, Pseudoemilia lacunosa Zone, Lower Quaternary.

Figure 5. Discoaster perplexus Bramlette and Riedel. Distal view showing specimen with 10 crystal elements.

Sample: 13-131A-4-1, $113 \mathrm{~cm}$. NN 19, Pseudoemilia lacunosa Zone, Lower Quaternary.

Figure 6. Cyclococcolithus leptoporus (Murray and Blackman). Proximal view of coccolith with outline of distal shield resembling that of Discoaster perplexus (Figure 5).

Sample: 13-130A-1, CC. NN 21, Late Quaternary.

\section{PLATE 9}

Cyclococcolithina macintyrei Bukry. Scale bar: 1 micron.

Figure 1. Detail of distal shield showing reversed imbrication near the margin of the crater.

Figure 2. Proximal view of coccolith with rather small proximal shield. 31 sutures.

Sample: 13-134-7-2, Top. NN 12, Ceratolithus tricorniculatus Zone, Lower Pliocene.

Figure 3. Proximal view of coccolith with 37 sutures, which are not meandering on the proximal shield.

Figure 4. Distal view of coccolith with 35 sutures and partitioned central aperture.

Figure 5. Proximal view of distal shield and central wall; proximal shield broken off. 32 sutures.

Figure 6. Central wall of a fragmentary coccolith similar to that of Figure 5 . The central aperture is subdivided by septa.

Sample: 13-132-12, CC. NN 15, Reticulofenestra pseudo umbilica Zone, Lower Pliocene.

\section{PLATE 10}

Cyclococcolithina macintyrei Bukry. Scale bar: 1 micron.

Figure 1. Distal view of a coccolith with 23 sutures, the margin of the proximal shield was also replicated and is visible through the transparent replica of the distal shield.

Figure 2. Oblique distal view of a coccolith with 27 sutures. Near the height of the crater there are three elements with "reversed imbrication".

Sample: 13-132-12, CC. NN 15, Reticulofenestra pseudoumbilica Zone, Lower Pliocene.

Figure 3. Distal view of a coccolith with part of the distal shield broken off, thus permitting a glance at the auxiliary spines holding the elements of the proximal shield. 24 sutures.

Sample: 13-132-14, CC. NN 15, Reticulofenestra pseudoumbilica Zone.
Figure 4. Proximal view of well-preserved coccolith with comparatively small proximal shield. 30 sutures.

Sample: 13-131-12, CC. NN 15, Reticulofenestra pseudoumbilica Zone.

Figure 5. Oblique distal view of coccolith with 27 sutures and reversed imbrication around the central crater.

Sample: 13-134-7-2, Top. NN 12, Ceratolithus tricorniculatus Zone, Lower Pliocene.

Figure 6. Oblique proximal side view of coccolith with 27 sutures, similar to that of Figure 4.

Sample: 13-132-12, CC. NN 15, Reticulofenestra pseudoumbilica Zone.

\section{PLATE 11}

Oolithothus cf. antillarum (Cohen). In Pliocene samples of the Mediterranean a small species of Oolithotus with broad elliptical outline and zigzag sutures was found. It differs from the Quaternary species by its smaller size and less excentricity. Scale bars: 1 micron.

Figures 1,2. Distal views of specimens with elliptical outline. Sample: 13-134-7-2, Top. NN 12, Ceratolithus tricorniculatus Zone, Lower Pliocene.

Figure 3. Distal side of subcircular specimen.

Sample: 13-132-12, CC. NN 15, Reticulofenestra pseudoumbilica Zone.

Figure 4. Specimen with subcircular outline and meandering sutures in proximal shield, similar to Cyclococcolithus leptoporus.

Sample: 13-134-7-2, Top. NN 12, Ceratolithus tricorniculatus Zone.

Figure 5. Proximal view of specimen with claw-shaped elements in proximal shield, which is slightly excentric.

Figure 6. Proximal view of a loose distal shield with central wall.

Sample: 13-132-12, CC. NN 15, Reticulofenestra pseudoumbilica Zone, Lower Pliocene.

\section{PLATE 12}

Scale bar: 5 microns. (Applies to all figures.)

Figures 1-6. Oolithothus antillarum (Cohen). Coccoliths with excentric division by 16 to 21 sutures. LM, normal light (Figures $1,3,4)$, positive phase contrast (Figure 6) and negative phase contrast (Figures 2, 5).

Figure 7. Discoaster perplexus Bramlette and Riedel. Specimen with 11 sutures, LM, normal light.

Figure 8. Discoaster perplexus Bramlette and Riedel. Specimen with 10 sutures, high focus.

Figure 9. Discoaster perplexus Bramlette and Riedel. Same specimen, low focus, normal light.

Figure 10. Cyclococcolithus sp. Specimen in low focus, LM, positive phase contrast.

Figure 11. Cyclococcolithus sp. Same specimen, high focus, normal light.

Figure 12. Pontosphaera scutellum (Kamptner). NL, positive phase contrast.

Sample: 13-130A-1, CC. NN 21, Late Quaternary.

\section{PLATE 13}

Scale bar: 1 micron.

Figure 1. Cyclococcolithus cf. cricotus Gartner. Distal view, secondary calcite growth.

Figure 2. Same specimen as Figure 1 in oblique distal view.

Figure 3. Cyclococcolithus cf. cricotus Gartner. Proximal view.

Sample: 13-130-3-1, $1 \mathrm{~cm}$. NN 19, Pseudoemilia lacunosa Zone, Lower Quaternary.

Figure 4. Cyclococcolithus aequiscutum Gartner. Plan view. Sample: 13-132-12, CC. NN 15, Reticulofenestra pseudoumbilica Zone, Lower Pliocene. 
Figure 5. Umbilicosphaera mirabilis Lohmann. Distal view.

Figure 6. Umbilicosphaera mirabilis Lohmann. Proximal view.

Sample: 13-130A-1, CC. NN 21, Emiliania huxley Zone, Late Quaternary.

\section{PLATE 14}

Scale bar: 1 micron.

Figure 1. Umbilicosphaera mirabilis Lohmann. Proximal view of a slightly recrystallized specimen.

Figure 2. Umbilicosphaera mirabilis Lohmann. Detached the distal shield.

Sample: $13-134-7-2,1 \mathrm{~cm}$. NN 12, Ceratolithus tricorniculatus Zone, Lower Pliocene.

Figure 3. Cyclococcolithus aequiscutum Gartner. Plan view; the broken-off rim of one shield permits a view of the equal-sized other shield.

Figure 4. Cyclolithella inflexa (Kamptner) Loeblich and Tappan. Plan view.

Figure 5. Cyclolithella inflexa (Kamptner) Loeblich and Tappan. Proximal view.

Figure 6. Cyclolithella cf. inflexa (Kamptner) Loeblich and Tappan. Proximal view.

Sample: 13-132-12, CC. NN 15, Reticulofenestra pseudoumbilica Zone, Lower Pliocene.

\section{PLATE 15}

Helicopontosphaera kamptneri Hay and Mohler syn. Helicosphaera carteri (Wallich) Kamptner. Scale bar: 1 micron.

Figure 1. Distal view of specimen with open slits.

Figure 2. Distal view of specimen with slits closed by some mashes of a grid.

Figure 3. Proximal view of specimen with large flange.

Figure 4. Proximal view of specimen with three slits.

Sample: 13-132-12, CC. NN 15, Reticulofenestra pseudoumbilica Zone, Lower Pliocene.

\section{PLATE 16}

Helicopontosphaera kamptneri Hay and Mohler syn. Helicosphaera carteri (Wallich) Kamptner. Scale bar: 1 micron.

Figure 1. Proximal oblique view.

Sample: 13-132-4-4, $100 \mathrm{~cm}$. NN 20, Gephyrocapsa oceanica Zone, Middle Quaternary.

Figure 2. Distal view.

Sample: 13-132-4-4, $100 \mathrm{~cm}$. NN 20, Gephyrocapsa oceanica Zone.

Figure 3. Proximal view of partly corroded specimen.

Sample: 13-130A-1, CC. NN 21, Late Quaternary.

Figure 4. Same specimen as in Figure 1 in side view.

Figure 5. Oblique side view showing curvature of flange.

Sample: 13-130-3-1, $127 \mathrm{~cm}$. NN 19/20, Lower to Middle Quaternary.

Figure 6. Side view of same specimen as in Figure 3.

\section{PLATE 17}

Scale bar: 1 micron.

Figures 1-4. Assemblage micrographs of nannoplankton after ultrasonication and subsequent washing and centrifugalization; the clay fraction has been removed.

Sample: 13-132-18-3, $25 \mathrm{~cm}$. NN 12, Ceratolithus tricorniculatus Zone, Lower Pliocene.
PLATE 18

Scale bar: 1 micron.

Figure 1. Scyphosphaera sp. Distal view of basal plate with open pores; and low rim.

Figure 2. Scyphosphaera sp. Distal view of basal plate with low rim. Pores almost entirely closed by recrystallization.

Figure 3. Pontosphaera japonica (Takayama) nov. comb. Proximal view showing characteristic striation of the inner (second) wall on the concave side; central areas with numerous fine pores (syn. Discolithina millepuncta Gartner).

Figure 4. Pontosphaera japonica (Takayama) nov. comb. Distal view of a partly corroded discolith.

Sample: 13-132-12, CC. NN 15, Reticulofenestra pseudoumbilica Zone, Lower Pliocene.

Figure 5. Pontosphaera japonica (Takayama) nov. comb. Proximal view of the basal plate showing indented margin (doubling of carbon coating!) and characteristic alignment of pores.

Sample: 13-130A-1, CC. NN 21, Emiliania huxleyi Zone, Upper Quaternary.

\section{PLATE 19}

Scale bars: 1 micron (Figures 1, 2, 5, 6 and 7); 5 microns (Figures 3 and 4 ).

Figure 1. Pontosphaera cf. pauciforata (Kamptner). Distal view.

Figure 2. Pontosphaera cf. pauciforata (Kamptner). Distal view. Sample: 13-130A-1, CC. NN 21, Late Quaternary.

Figure 3. Pontosphaera sp. Distal view, aluminum-shadowing; reversed print, normal light.

Figure 4. Pontosphaera sp. Distal view, aluminum-shadowing; reversed print, $\mathrm{x}$-nic, gypsum red.

Sample: 13-134E-2, CC. NN 16, Discoaster surculus Zone, Upper Pliocene.

Figure 5. Pontosphaera sp. Distal view of an over-calcified discolith Sample: 13-132-12, CC. NN 15, Reticulofenestra pseudoumbilica Zone, Lower Pliocene.

Figure 6. Pontosphaera sp. Distal View.

Sample: $13-132-18-3,25 \mathrm{~cm}$. NN 12, Ceratolithus tricorniculatus Zone, Lower Pliocene.

Figure 7. Pontosphaera sp. Distal view of a partly recrystallized discolith.

Sample: 13-125-4, CC. NN 18, Discoaster brouweri Zone, Upper Pliocene.

\section{PLATE 20}

Scale bar: 1 micron.

Figure 1. Pontosphaera alboranensis Bartolini. Proximal view of discolith; the cracks in the basal plate except the central longitudinal slit seem to be secondary damages.

Figure 2. Pontosphaera alboranensis Bartolini. Close-up of same specimen as Figure 1 after slight tilting.

Sample: 13-130A-1, CC. NN 21, Emiliania huxleyi Zone, Upper Quaternary.

Figure 3. Scyphosphaera apsteini Lohmann. Lovadolith with secondary calcite overgrowth; lateral view; the first wall (below) is missing and thus a distinct groove is exposed.

Sample: 13-130A-1, CC. NN 21, Emiliania huxleyi Zone, Upper Quaternary.

Figure 4. Scyphosphaera apsteini Lohmann. Oblique apical view of lopadolith; in spite of some calcite overgrowth the ornamentation of spiral grooves crossing longitudinal grooves is visible. Sample: 13-132-7-2, $90 \mathrm{~cm}$. NN 19, Pseudoemilia lacunosa Zone, Lower Quaternary.

Figure 5. Scyphosphaera apsteini Lohmann. Oblique lateral view of the basal plate with perforated central area and the basket-shaped shell composed of slantingly striated first wall and richly ornamented second wall. 
Figure 6. Scyphosphaera apsteini Lohmann. Close-up of same specimen; proximal view showing striation of first wall.

Sample: 13-130A-1, CC. NN 21, Emiliania huxleyi Zone, Upper Quaternary.

\section{PLATE 21}

Scyphosphaera apsteini Lohmann. Scale bar: 1 micron.

Figure 1. Oblique apical view of lopadolith, which to its greater part is composed of elongated curved elements (derivates of the second (inner) wall.

Figure 2. Axial apical view of lopadolith showing concentrical arrangement of the elements of the apical periphery.

Figure 3. Side view of a lopadolith. On the left side the outer wall (first wall) is preserved.

Figure 4. Side view of a lopadolith with missing outer wall; only second wall preserved.

Figure 5. Inner view of a split-fragment of lopadolith. The concave side of the inner second wall was replicated, permitting a view of one element of the outer first wall (left).

Figure 6. Proximal or basal view of a lopadolith showing ultrastructure of basal plate with pores and striation of the outer first wall.

Sample: 13-132-12, CC. NN 15, Reticulofenestra pseudoumbilica Zone, Lower Pliocene.

\section{PLATE 22}

Scale bar: 1 micron.

Figure 1. Scyphosphaera pulcherrima Deflandre. Side view showing surface ornamentation of lopadolith; below the obliquely striated outer or first wall, a derivate of the basal plate, in center the corrugated second wall forming the belly of the lopadolith; above the flaring collar showing the striation of the second wall, however only in axial direction.

Sample: 13-134-7-2, Top. NN 12, Ceratolithus tricorniculatus Zone, Lower Pliocene.

Figure 2. Scyphosphaera pulcherrima Deflandre. Inner view of a lopadolith-fragement with only longitudinal striation on the inner concave surface.

Sample: 13-132-12, CC. NN 15, Reticulofenestra pseudoumbilica Zone, Lower Pliocene.

Figure 3. Scyphosphaera sp. Axial apical view.

Sample: 13-134-7-2, Top. NN 12, Ceratolithus tricorniculatus Zone, Lower Pliocene.

Figure 4. Scyphosphaera intermedia Deflandre. Oblique lateral view of the proximal half of a lopadolith. First wall with inclined striation partly corroded.

Sample: 13-132-12, CC. NN 15, Reticulofenestra pseudoumbilica Zone, Lower Pliocene.

Figure 5. Scyphosphaera sp. Oblique proximal view of the basal plate of a lopadolith showing system of pores aligned in concentrical rings; outer margin of basal plate indented.

Sample: 13-134-7-2 Top. NN 12, Ceratolithus tricorniculatus Zone, Lower Pliocene.

\section{PLATE 23}

Scale bar: 5 microns. (Applies to all figures.)

Figure 1. Scyphosphaera apsteini Lohmann. Al-shadowed, normal light.

Figure 2. Scyphosphaera apsteini Lohmann. Same specimen as in Figure 1 in $x$-nic.

Figure 3. Scyphosphaera cf. apsteini Lohmann. Al-shadowed, normal light.

Figure 4. Scyphosphaera cf. apsteini Lohmann. Same specimen as in Figure 3 in $x$-nic.

Figure 5. Scyphosphaera cf. apsteini Lohmann. Al-shadowed, normal light.
Figure 6. Scyphosphaera cf. apsteini Lohmann. Same specimen as in Figure 5 in $\mathrm{x}$-nic.

Sample: $13-124-2-4,77 \mathrm{~cm}$. NN 17, Discoaster pentaradiatus Zone, Upper Pliocene.

Figure 7. Scyphosphaera apsteini Lohmann. Al-shadowed, reversed print, normal light.

Sample: 13-134-7-2, $1 \mathrm{~cm}$. NN 12, Xeratolithus tricorniculatus Zone, Lower Pliocene.

Figure 8. Scyphosphaera expansa Bukry and Percival. Al-shadowed, normal light.

Figure 9. Scyphosphaera expansa Bukry and Percival. Same specimen as in Figure 8 in $x$-nic + gypsum red.

Figures 10-12. Lithostromation perdurum Deflandre. Plan view, al-shadowed, normal light; medium focus (10), high focus (11) and phase contrast (12).

Sample: $13-124-2-4,77 \mathrm{~cm}$. NN 17, Discoaster pentaradi. atus Zone, Upper Pliocene.

\section{PLATE 24}

Scale bar: 5 microns. (Applies to all figures.)

Figure 1. Scyphosphaera recurvata Deflandre. Lopadolith, normal light.

Figure 2. Scyphosphaera recurvata Deflandre. Same specimen as in Figure 1 in $x$-nic.

Sample: $13-125-4-5,120 \mathrm{~cm}$. NN 18, Discoaster brouweri Zone, Upper Pliocene.

Figure 3. Scyphosphaera turris Kamptner. Al-shadowed, direct print, normal light

Sample: 13-134E-2, CC. NN 16, Discoaster surculus Zone, Upper Pliocene.

Figure 4. Scyphosphaera turris Kamptner. Al-shadowed, direct print, normal light.

Figure 5. Scyphosphaera turris Kamptner. Same specimen as in Figure $4 \mathrm{x}$-nic + gypsum red.

Figure 6. Scyphosphaera globulate Bukry and Percival. Alshadowed, reversed print, normal light.

Figure 7. Scyphosphaera intermedia Deflandre. Al-shadowed, reversed print, normal light.

Sample: 13-134-7-2 $1 \mathrm{~cm}$. NN 12, Ceratolithus tricorniculatus Zone, Lower Pliocene.

Figure 8. Scyphosphaera sp. Intermediary form between Sc. amphora and Sc. intermedia. Al-shadowed, direct print, normal light.

Figure 9. Scyphosphaera amphora Deflandre. All-around Alshadowed, direct print, normal light.

Sample: 13-134E-2, CC. NN 16, Discoaster surculus Zone, Upper Pliocene.

\section{PLATE 25}

Scale bar: 5 microns. (Applies to all figures.)

Figure 1. Scyphosphaera cf. amphora Deflandre. Normal light.

Figure 2. Scyphosphaera cf. amphora Deflandre. Same specimen as in Figure 1 in phase contrast.

Sample: 13-125A-3-1-34, $35 \mathrm{~cm}$. NN 16, Discoaster surculus Zone, Upper Pliocene.

Figure 3. Scyphosphaera campanula Deflandre. Normal light.

Figure 4. Scyphosphaera turris Kamptner. Al-shadowed, direct print, normal light.

Sample: 13-125A-2, CC. NN 17, Discoaster pentaradiatus Zone, Upper Pliocene.

Figure 5. Scyphosphaera cf. amphora Deflandre. Al-shadowed, direct print, normal light.

Sample: 13-134-7-2, $1 \mathrm{~cm}$. NN 12, Ceratolithus tricorniculatus Zone, Lower Pliocene.

Figure 6. Scyphosphaera cf. porosa Kamptner. X-nic. Sample: $13-125-4-5,120 \mathrm{~cm}$ and $13-125 \mathrm{~A}-2-1,75 \mathrm{~cm}$. NN 18, Discoaster brouweri Zone, Upper Pliocene. 
Figure 7. Scyphosphaera halldali Deflandre. Al-shadowed, direct print, normal light, Holotype.

Sample: 13-134-7-2, $1 \mathrm{~cm}$. NN 12, Ceratolithus tricorniculatus Zone, Upper Pliocene.

Figure 8. Scyphosphaera pulcherrima Deflandre. Small lopadolith, Al-shadowed, direct print, normal light.

Figure 9. Scyphosphaera pulcherrima Deflandre. Al-shadowed, reversed print, normal light.

Sample: 13-125A-2, CC. NN 17, Discoaster pentaradiatus Zone, Upper Pliocene.

Figure 10. Scyphosphaera pulcherrima Deflandre. Normal light + polarizer.

Sample: $13-125-4-5,120 \mathrm{~cm}$ and 13-125A-2-1, $75 \mathrm{~cm}$. NN 18, Discoaster brouweri Zone, Upper Pliocene.

\section{PLATE 26}

Rhabdosphaera cf. stylifera Lohmann. Scale bar: 1 micron.

Figure 1. Lateral view showing the spiral arrangement of the elements in the flaring stem.

Figure 2. Distal view of shield, stem not developed. Marginal elements more compact than in the quaternary specimens of Rhabdosphaera clavigera.

Figure 3. Oblique distal view of a similar shield without stem.

Figure 4. Proximal view of a shield, showing the spiral arrangement of the elements more clearly than the distal views.

Sample: 13-132-12, CC. NN 15, Reticulofenestra pseudoumbilica Zone, Lower Pliocene.

\section{PLATE 27}

Rhabdosphaera clavigera Murray and Blackman. Scale bar: 1 micron.

Figure 1. Oblique distal view of a rhabdolith.

Figure 2. Oblique distal view of shield of same specimen. The elements of the shield are inclined counterclockwise, the marginal elements are claw-shaped.

Figure 3. Oblique proximal view of a basal plate.

Sample: 13-130A-1, CC. NN 21, Emiliania huxleyi Zone, Late Quaternary.

Figure 4. Lateral view showing the spiral arrangement of the elements in the club-shaped stem. In background Gephyrocapsa ocenaica distal view.

Sample: 13-132-1-5, $74 \mathrm{~cm}$. NN 21, Emiliania huxleyi Zone, Upper Quaternary.

Figure 5. Oblique distal view of shield and lower part of the stem, slightly recrystallized.

Sample: 13-132-18-3, $25 \mathrm{~cm}$. NN 12, Ceratolithus tricorniculatus Zone, Lower Pliocene.

\section{PLATE 28}

Scale bar: 1 micron.

Figure 1. Syracosphaera molischi Schiller. Proximal view.

Figure 2. Syracosphaera molischi Schiller. Distal view.

Sample: 13-132-12, CC. NN 15, Reticulofenestra pseudoumbilica Zone, Lower Pliocene.

Figure 3. Syracosphaera molischi Schiller. Oblique proximal view of a smaller specimen with fewer radial rods.

Sample: 13-134-7-2, cm. NN 12, Ceratolithus tricorniculatus Zone, Lower Pliocene.

Figure 4. Syracosphaera molischi Schiller. Distal view; the straight rods of the central area are overlapping in the center.

Figure 5. Syracosphaera molischi Schiller. Oblique proximal view of rim.

Sample: 13-132-12, CC. NN 15, Reticulofenestra pseudoumbilica Zone, Lower Pliocene.

Figure 6. Syracosphaera molischi Schiller. Plan view; transmission electron micrograph of original caneolith.

Sample: 13-125-4, CC. NN 18, Discoaster brouweri Zone.

\section{PLATE 29}

Syrachosphaera dalmatica Kamptner. Holococcoliths of the motile phase in life cycle of the flagellate; the coccoliths are composed of very small microcrystals, which after some fossilization are no longer discernible. Scale bars: 1 micron.

Figure 1. Coccolith with eight marginal pores; distal view.

Figure 2. Coccolith with nine marginal pores and large central knob; distal view.

Figure 3. Coccolith with seven marginal pores and two central pores; proximal view.

Figure 4. Coccoliths with eight marginal and six central pores; distal view.

Figure 5. Oblique side view of coccoliths with large central pore.

Figure 6. Lateral view of coccolith showing conical rim and elevated crown; the pores appear white.

Sample: 13-132-12, CC. NN 15, Reticulofenestra pseudoumbilica Zone, Lower Pliocene.

\section{PLATE 30}

Scale bar: 1 micron.

Figure 1. Thoracosphaera sp. With "escape-window"; a small coccolith of Gephyrocapsa oceanica is adhering to the rough surface.

Sample: $13-132-4-4,100 \mathrm{~cm}$. NN 20, Gephyrocapsa oceanica Zone, Middle Quaternary.

Figure 2. Rhabdothosax. About 150 to 200 spines are originating from the composite shell, one spine from each irregular element.

Sample: $13-132-18-3,25 \mathrm{~cm}$. NN 12, Ceratolithus tricorniculatus Zone, Lower Pliocene.

Figure 3. Tessellatolithus dentatus Haq. Irregular elements fitting together in a "jig-saw puzzle"-pattern.

Sample: 13-130-3-1, $127 \mathrm{~cm}$. NN 19, Pseudoemilia lacunosa Zone, Lower Quaternary.

Figure 4. Thoracosphaera heimi (Lohmann) Kamptner. External view of shell composed of characteristic perforate elements.

Sample: 13-130A-1, CC. NN 21, Emiliania huxleyi Zone, Late Quaternary.

Figure 5. Nannofossil-assemblage with a Thoracosphaera shell (right) and several cyclococcoliths (left) and helicopontospheres (center and above).

Sample: 13-132-4-4, $100 \mathrm{~cm}$. NN 20, Gepnyrocapsa oceanica Zone, Middle Quaternary.

\section{PLATE 31}

Scale bar: 5 microns. (Applies to all figures.)

Figure 1. Discoaster brouweri Tan Sin Hok. Normal light.

Figure 2. Discoaster brouweri Tan Sin Hok. Al-shadowed, normal light, reversed print.

Sample: 13-134-7-2, $1 \mathrm{~cm}$. NN 12, Ceratolithus tricorniculatus Zone, Lower Pliocene.

Figure 3. Discoaster pentaradiatus Tan Sin Hok. Detached arm with typical bifurcation; phase contrast.

Sample: $13-132-10-5, \mathrm{~cm}$. NN 17.

Figure 4. Discoaster pentaradiatus Tan Sin Hok. Concave side in low focus, phase contrast.

Figure 5. Discoaster pentaradiatus Tan Sin Hok. Same specimen in high focus.

Figure 6. Discoaster pentaradiatus Tan Sin Hok. Two asteroliths without bifurcated tips. Normal light.

Sample: $13-124-2-4, \quad 77 \mathrm{~cm}$. NN 17, Discoaster pentaradiatus Zone.

Figure 7. Discoaster cf. surculus Martini and Bramlette. Asterolith with smooth rays. Al-shadowed, normal light, direct print.

Figure 8. Discoaster cf. surculus Martini and Bramlette. Same specimen as in Figure 7 in phase contrast.

Sample: 13-134E-2, CC. NN 16, Discoaster surculus Zone, Upper Pliocene.

Figure 9. Discoaster cf. brouweri Tan Sin Hok. Six-rayed asterolith, phase contrast. 
Figure 10. Discoaster cf. brouweri Tan Sin Hok. Phase contrast. Sample: $13-125 \mathrm{~A}-3-1,34-35 \mathrm{~cm}$. NN 16.

Figure 11. Cyclococcolithus macintyrei Bukry. Al-shadowed, reversed print, normal light.

Sample: 13-134-7-2, $1 \mathrm{~cm}$. NN 12, Ceratolithus tricorniculatus Zone.

Figures 12,13. Discolithina cf. macropora Deflandre. In positive and negative phase contrast.

Sample: $13-124-2-4,77 \mathrm{~cm}$. NN 17, Discoaster pentaradiatus Zone.

Figure 14. Scapholithus fossilis Deflandre. Phase contrast.

Sample: $13-125 \mathrm{~A}-3-1,34-35 \mathrm{~cm}$. NN 16 .

\section{PLATE 32}

Scale bar: 5 microns (Figures 1-3); 1 micron (Figures 4-6).

Figure 1. Discoaster surculus Martini and Bramlette. Six-radiate asterolith, distal view, LM, normal light.

Sample: 13-134-7-2, $1 \mathrm{~cm}$. NN 12, Ceratolithus tricorniculatus Zone, Lower Pliocene.

Figure 2. Discoaster surculus Martini and Bramlette. Six-radiate asterolith with robust rays, proximal view, LM, normal light, reversed print of aluminum coasted specimen.

Figure 3. Discoaster surculus Martini and Bramlette. Six-radiate asterolith with delicate rays and inconspicuous bifurcation; proximal view; LM, normal light, reversed print of aluminumcoated specimen.

Sample: 13-134E-2, CC. NN 16, Discoaster surculus Zone, Upper Pliocene.

Figure 4. Discoaster surculus Martini and Bramlette. Six-radiate asterolith, proximal view central star with portions like in $D$. trinus.

Figure 5. Discoaster cf. obtusus Gartner. Six-radiate asterolith with pronounced ridges and central crater; distal view.

Figure 6. Discoaster cf. obtusus Gartner. Six-radiate asterolith, proximal view, centeral area dotted (? corroded).

Sample: 13-132-12, CC. NN 15, Reticulofenestra pseudoumbilica Zone, Lower Pliocene.

\section{PLATE 33}

Discoaster surculus Martini and Bramlette. Scale bar: 1 micron.

Figure 1. Six-radiate asterolith, proximal view with "trinus"partition covering the central area.

Sample: $13-134-7-2,1 \mathrm{~cm}$. NN 12, Ceratolithus tricorniculatus Zone, Lower Pliocene.

Figure 2. Six-radiate asterolith, distal view.

Figure 3. Six-radiate asterolith, proximal view, with ridges of central area extending onto the rays.

Figure 4. Six-radiate asterolith, distal view.

Figure 5. Central area of a six-radiate asterolith decorated with large flaming star extending into the ridges of the rays. Proximal view.

Sample: 13-132-12, CC. NN 15, Reticulofenestra pseudoumbilica Zone, Lower Pliocene.

\section{PLATE 34}

Scale bar: 1 micron.

Figure 1. Discoaster challengeri Bramlette and Riedel. Proximal view.

Figure 2. Discoaster challengeri Bramlette and Riedel. Same specimen as in Figure 1 in oblique proximal view.

Figure 3. Discoaster surculus Martini and Bramlette. Distal view.

Figure 4. Discoaster brouweri Tan Sin Hok. Distal view.

Figure 5. Discoaster pentaradiatus Tan Sin Hok. Oblique distal view.

Figure 6. Discoaster pentaradiatus Tan Sin Hok. Proximal view.

Figure 7. Discoaster sp. Proximal view.

Sample: 13-132-18-3, $25 \mathrm{~cm}$. NN 12, Ceratolithus tricorniculatus Zone, Lower Pliocene.

\section{PLATE 35}

Scale bar: 1 micron.

Figure 1. Discoaster tamalis Kamptner. Four-radiate asterolith, proximal view.

Figure 2. Discoaster tamalis Kamptner. Four-radiate asterolith, proximal view.

Figure 3. Discoaster cf. asymmetricus Gartner. Five-radiate asterolith, distal view.

Figure 4. Discoaster cf. asymmetricus Gartner. Five-radiate asterolith, proximal view.

Figure 5. Discoaster cf. asymmetricus Gartner. Five-radiate asterolith, proximal view.

Figure 6. Discoaster cf. asymmetricus Gartner. Five-radiate asterolith, proximal view.

Sample: 13-132-12, CC. NN 15, Reticulofenestra pseudoumbilica Zone, Lower Pliocene.

PLATE 36

Scale bar: 5 microns. (Applies to all figures.)

Figure 1. Discoaster tamalis Kamptner. Concave side of four-rayed asterolith, aluminum-shadowing, reversed print.

Figure 2. Discoaster asymmetricus Gartner. Concave side of fiveradiate asterolith, aluminum-shadowing, reversed print.

Sample: 13-134E-2, CC. NN 16, Discoaster surculus Zone, Upper Pliocene.

Figure 3. Discoaster cf. brouweri Tan Sin Hok. Proximal view of six-radiate asterolith; LM, normal light, direct print.

Sample: 13-134-7-2, Top. NN 12, Ceratolithus tricorniculatus Zone, Lower Pliocene.

Figure 4. Ceratolithus tricorniculatus Gartner. Specimens with hardly recognizable spur; normal light.

Figure 5. Ceratolithus tricorniculatus Gartner. Specimens with hardly recognizable spur; negative phase contrast.

Figure 6. Ceratolithus tricorniculatus Gartner. Specimens with well-developed spur; positive phase contrast.

Figures 7,8. Ceratolithus tricorniculatus Gartner. Specimens with well-developed spur; normal light.

Sample: $13-125 \mathrm{~A}-6-1,15 \mathrm{~cm}$. NN 13, Ceratolithus rugosus Zone, Lower Pliocene.

Figure 9. Colithus rugosus Bukry and Bramlette, Plan view after aluminum-shadowing, reversed print.

Sample: 13-134E-2, CC. NN 16, Discoaster surculus Zone, Upper Pliocene.

Figure 10. Braarudosphaera bigelowi (Graan and Braarud) Deflandre. Distal sides of large pentaliths after aluminumshadowing; direct print. Picture shows a concentrical striation, which is due to the crystal-arrangement of the elements.

Sample: 13-132-7, CC. NN 19, Pseudoemilia lacunosa Zone, Lower Quaternary.

Figure 11. Braarudosphaera bigelowi (Graan and Braarud) Deflandre. Distal sides of large pentaliths after aluminumshadowing; reversed print. Picture shows a concentrical striation, which is due to the crystal-arrangement of the elements. Sample: 13-132-7, CC. NN 19, Pseudoemilia lacunosa Zone, Lower Quaternary.

\section{PLATE 37}

Ceratolithus tricorniculatus Gartner. Scale bar: 1 micron.

Figure 1. Ceratolith with only two horns of unequal length.

Figure 2. Ceratolith with two horns and two small humps on the curved arc.

Figure 3. Ceratolith with an unsymmetrically positioned third horn. Figure 4. Ceratolith with a groove underneath the third horn.

Figure 5. Ceratolith with the shorter primary horn split and foliose.

Figure 6. Ceratolith with split horn.

Sample: 13-125A-6-1, $15 \mathrm{~cm}$. NN 13, Ceratolithus rugosus Zone, Lower Pliocene. 


\section{PLATE 38}

Nannofossil-assemblage of Lower Pliocene nanno ooze. The clayfraction was removed by ultrasonication and repeated centrifugalization. Scale bar: 1 micron.

Figure 1. Scyphosphaera sp. Lateral view (above); Thoracosphaera sp. (below) and several coccoliths.

Figure 2. Two Scyphosphaera-lopadoliths, one discoaster and several coccoliths.

Figure 3. Three discoasters and numerous coccoliths.

Figure 4. A coccosphere of Coccolithus pelagicus (Wallich) Schiller. Sample: 13-132-18-3, $25 \mathrm{~cm}$. NN 12, Ceratolithus tricorniculatus Zone.

\section{PLATE 39}

All figures lightmicorgraphs, normal light. Scale bar: 5 microns. (Applies to all figures.)

Figure 1. Discoaster bollii Martini and Bramlette.

Figure 2. Discoaster stellulus Gartner.

Figure 3. Discoaster bollii Martini and Bramlette.

Figure 4. Discoaster cf. bollii Martini and Bramlette.

Figure 5. Discoaster kugleri Martini and Bramlette.

Figure 6. Discoaster kugleri Martini and Bramlette.

Figure 7. Discoaster cf. argutus Hay.

Figure 8. Discoaster divaricatus Hay.

Figure 9. Discoaster dilatus Hay.

Figure 10. Discoaster sp.

Figure 11. Discoaster divaricatus Hay.

Figure 12. Discoaster musicus Stradner.

Sample: $13-124-7-1,70-71 \mathrm{~cm}$. Upper Miocene.

\section{PLATE 40}

All figures either normal light (odd numbers) or phase contrast. Scale bar: 5 microns. (Applies to all figures.)

Figures 1,2. Discoaster intercalaris Bukry. Normal light and phase contrast.

Figures 3,4. Discoaster cf. aulakos Gartner. Over-calcified asterolith.

Figures 5,6. Discoaster aulakos Gartner.

Figures 7,8. Discoaster aulakos Gartner.

Figures 9,10. Discoaster ex gr. variabilis Martini and Bramlette.

Figures 11,12. Discoaster sp. Partly corroded asterolith.

Sample: 13-134-7, CC. Upper Miocene.

\section{PLATE 41}

All figures in normal light except Figure 3 (phase contrast). Scale bar: 5 microns. (Applies to all figures.)

Figure 1. Discoaster cf. intercalaris Bukry.

Figure 2. Discoaster loeblichii Bukry.

Figure 3. Discoaster loeblichii Bukry. Same specimen as in Figure 2 in phase contrast.

Figure 4. Discoaster $\mathrm{cf}$. variabilis Martini and Bramlette.

Figure 5. Discoaster variabilis Martini and Bramlette.

Figure 6. Discoaster cf. dilatus Hay.

Figure 7. Discoaster cf. icarus n.sp.

Figure 8. Discoaster variabilis pansus Bukry and Percival.

Figure 9. Discoaster variabilis pansus Bukry and Percival.

Figure 10. Discoaster icarus n.sp. Holotype.

Figure 11. Discoaster icarus n.sp. Paratype.

Sample: 13-134-7, CC. Upper Miocene.

\section{PLATE 42}

All figures normal light unless otherwise stated. Scale bar: 5 microns. (Applies to all figures.)
Figure 1. Discoaster icarus n.sp. Small asterolith.

Figure 2. Discoaster icarus n.sp. Asterolith with interbranchextensions appearing dark.

Figure 3. Discoaster icarus n.sp. Asymmetrical asterolith contrast.

Figure 4. Discoaster icarus n.sp. Middle-sized asterolith.

Figure 5. Discoaster icarus n.sp. Paratype.

Figure 6. Discoaster icarus n.sp. Phase contrast.

Figure 7. Discoaster $\mathrm{cf}$. saundersi Hay. Possibly reworked.

Figure 8. Discoaster cf. saundersi Hay. Same specimen as in Figure 7 in phase contrast.

Figure 9. Discoaster icarus n.sp. Over-calcified.

Figure 10. Discoaster icarus n.sp. Large asterolith, heavily overcalcified.

Sample: 13-134-7, CC. Upper Miocene Zone.

PLATE 43

Scale bar: 5 microns. (Applies to all figures.)

Figure 1. Discoaster sp. Phase contrast.

Figure 2. Discoaster aulakos Gartner. Normal light.

Figure 3. Discoaster aulakos Gartner. Phase contrast.

Figure 4. Discoaster obtusus Gartner. Normal light, low focus.

Figure 5. Discoaster cf. aulakos Gartner. Phase contrast.

Figure 6. Discoaster obtusus Gartner. Same as Figure 4, high focus.

Figure 7. Discoaster cf. aulakos Gartner. Phase contrast.

Figure 8. Discoaster cf.challengeri mediterraneus Cati and Borsetti.

Figure 9. Discoaster channengeri mediterraneus Cati and Borsetti.

Figure 10. Discoaster cf. aulakos Gartner. Over-calcified asterolith in normal light.

Figure 11. Discoaster sp. Over-calcified asterolith; phase contrast.

Figure 12. Discoaster cf. trinidadensis Hay. Normal light. Sample: 13-120-1, CC. Lower Miocene.

\section{PLATE 44}

Scale Bar: 1 micron.

Figure 1. Discoaster deflandrei Bramlette and Riedel. Distal view. Figure 2. Discoaster cf. aulakos Gartner. Distal view.

Figure 3. Discoaster aulakos Gartner. Distal view.

Figure 4. Discoaster deflandrei Bramlette and Riedel. Proximal view.

Figure 5. Discoaster deflandrei Bramlette and Riedel. Proximal view showing central area and rounded interray contour.

Figure 6. Discoaster cf. aulakos Gartner. Distal view; the notch at the tip of the rays is broad and shallow.

Sample: $13-120-1$, CC. Lower Miocene.

\section{PLATE 45}

Scale bar: 1 micron.

Figure 1. Discoaster obtusus Gartner. Distal view.

Figure 2. Discoaster cf. aulakos Gartner. Distal view.

Figure 3. Discoaster aulakos Gartner. Distal view.

Figure 4. Discoaster cf. aulakos Gartner. Proximal view.

Figure 5. Discoaster cf. aulakos Gartner. Proximal view.

Figure 6. Discoaster cf. aulakos Gartner. Proximal view. Sample: $13-120-1$, CC. Lower Miocene.

\section{PLATE 46}

Scale bars: 1 micron (Figures 1-5); 5 microns (Figure 6).

Figure 1. Discoaster obtusus Gartner. Proximal view. Sample: 13-134-7, CC. NN 11, Upper Miocene.

Figure 2. Discoaster aulakos Gartner. Distal view.

Figure 3. Discoaster cf. deflandrei Bramlette and Riedel.

Figure 4. Discoaster aulakos Gartner. Proximal view.

Figure 5. Sphenolithus abies Deflandre. Lateral view.

Figure 6. Coccolithus cf. pelagicus (Wallich) Schiller. Distal view; LM, normal light. Sample: 13-120-1, CC. Lower Miocene. 


\section{PLATE 47}

Scale bar: 1 micron.

Figure 1. Cyclicargolithus floridanus (Roth and Hay) Bukry. Distal view of coccolith with recrystallized inner circle of crystal plates (wall).

Figure 2. Cyclicargolithus floridanus (Roth and Hay) Bukry. Distal view showing imbrication of the crystal plates forming the wall.

Figure 3. Cycliocargolithus floridanus (Roth and Hay) Bukry. Close-up of distal shield and the inner circle of the "wall"crystallites.

Figure 4. Coccolithus pelagicus (Wallich) Schiller. Proximal view of coccolith with comparatively small proximal shield consisting of two cycles of crystallites.

$$
\text { Sample: 13-120-1, CC. Lower Miocene. }
$$

Figure 5. Cyclicargolithus floridanus (Roth and Hay) Bukry. Proximal view showing the proximal shield, which consists of only one circle of crystallites.

Figure 6. Cyclicargolithus floridanus (Roth and Hay) Bukry. Proximal view of coccolith with damaged proximal shield.

\section{PLATE 48}

Scale bar: 5 microns. (Applies to all figures.)

Figure 1. Nannoconus steinmanni Kamptner. Side view.

Figure 2. Nannoconus steinmanni Kamptner. Side view, x-nic.

Figure 3. Nannoconus steinmanni Kamptner. Same specimen as in Figure 2 in normal light.

Figure 4. Nannoconus cf. bucheri Brönniman. Side view, normal light.

Figure 5. Nannoconus cf. bucheri Brönniman. Same specimen as in Figure 4 in $\mathrm{x}$-nic.

Figure 6. Parhabdolithus embergeri Noël. Normal light.

Figure 7. Parhabdolithus embergeri Noël. Same specimen as in Figure 6 in $\mathrm{x}$-nic.

Figure 8. Parhabdolithus embergeri Noël. Normal light.

Figure 9. Watznaueria barnesae Black (Perch-Nielsen). X-nic.

Figure 10. Micrantholithus cf. obtusus. X-nic.

Figure 11. Micrantholithus cf. obtusus. Normal light.

Figure 12. Micrantholithus cf. obtusus. Same specimen as in Figure 11 in $\mathrm{x}$-nic.

Sample: $13-120-4$, CC. Upper part of Lower Cretaceous.

\section{PLATE 49}

Scale bar: 1 micron

Figure 1. Watznaueria barnesae (Black) Perch-Nielsen. Distal view. Figure 2. Watznaueria barnesae (Black) Perch-Nielsen. Distal view, central area compact.

Figure 3. Gruciellipsis cuvillieri (Manivit) Thierstein. Distal view of coccolith with axial cross composed of small crystal elements.

Figure 4. Cruciellipsis chiastia (Worsley) Thierstein. Distal view of coccolith with axial cross composed or large crystal elements resembling a "tetralithus".

Figure 5. Parhabdolithus cf. embergeri Noël. Distal view.

Figure 6. Parhabdolithus cf. embergeri Noël. Proximal view. Sample: 13-120-4, CC. Upper part of Lower Cretaceous.

\section{PLATE 50}

Scale bar: 1 micron.

Figure 1. Complete coccosphere of Watznaueria barnesae (Black) Perch-Nielsen.

Figure 2. Coccosphere of Watznaueria barnesae (Black) PerchNielsen. Shell partly opened and showing secondary calcite growth inside.

Figure 3. Coccosphere of Watznaueria barnesae (Black) PerchNielsen. Calcite rhombohedrons formed due to oversaturated calcium carbonate solution below bottom.

Figure 4. Cruciellipsis cuvillieri (Manivit) Thierstein. Distal view.

Figure 5. Parhabdolithus $\mathrm{cf}$. embergeri Noël. Proximal view.

Figure 6. Parhabdolithus cf. embergeri Noël. Distal view. Sample: 13-120-7-1, $95 \mathrm{~cm}$. Lower Cretaceous.

\section{PLATE 51}

Fragments of dinoflagellate tests. Scale bars: 5 microns in Figures 1-4 (LM and 1 micron in Figures 5 and 6 (SEM).

Figures 1-6. After the dissolution of the greater part of the test, only the ridges are preserved at their reinforced juncture. Usually two of them are curved or undulate and symmetrical in respect to a third ridge, which is more straight. These pseudonannofossils do not consits of calcium carbonate, and thus have optical properties differing from those of calcareous nannoplankton.

Sample: 13-125-4, CC. NN 18, Discoaster brouweri Zone, Upper Pliocene. 